\title{
Geology, Hydrology, and Water Quality of the Surficial Aquifer System in Volusia County, Florida
}

By G.G. Phelps

\section{U.S. GEOLOGICAL SURVEY}

Water-Resources Investigations Report 90-4069

Prepared in cooperation with

VOLUSIA COUNTY 


\section{U.S. DEPARTMENT OF THE INTERIOR \\ MANUEL LUJAN, JR., Secretary}

\section{U.S. GEOLOGICALSURVEY}

Dallas L. Peck, Director

For additional information write to:

District Chief

U.S. Geological Survey

Suite 3015

227 North Bronough Street

Tallahassee, Florida 32301
Copies of this report can be purchased from:

U.S. Geological Survey

Books and Open-File Reports

Federal Center, Building 810

Box 25425

Denver, Colorado 80225 


\section{CONTENTS}

Page
Pa

Conversion factors $\ldots \ldots \ldots \ldots \ldots \ldots \ldots \ldots \ldots \ldots \ldots \ldots \ldots \ldots \ldots \ldots \ldots \ldots \ldots$

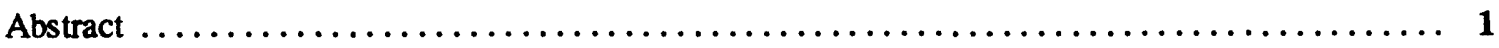

Introduction $\ldots \ldots \ldots \ldots \ldots \ldots \ldots \ldots \ldots \ldots \ldots \ldots \ldots \ldots \ldots \ldots \ldots \ldots \ldots \ldots \ldots \ldots$

Purpose and scope $\ldots \ldots \ldots \ldots \ldots \ldots \ldots \ldots \ldots \ldots \ldots \ldots \ldots \ldots \ldots \ldots \ldots \ldots \ldots \ldots \ldots \ldots \ldots$

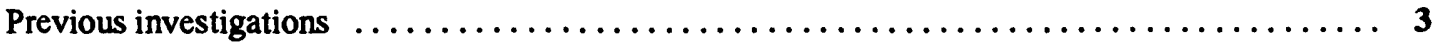

Well records and well-numbering system $\ldots \ldots \ldots \ldots \ldots \ldots \ldots \ldots \ldots \ldots \ldots \ldots$

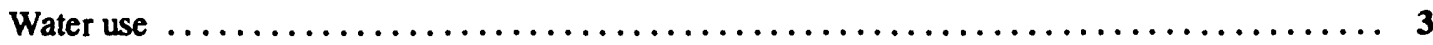

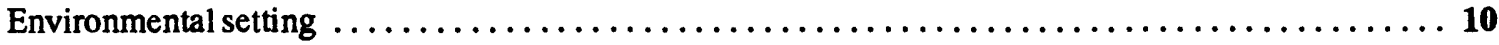

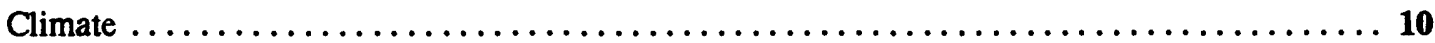

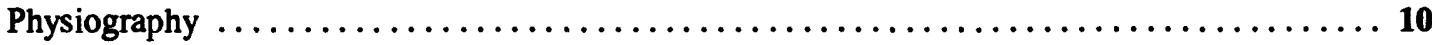

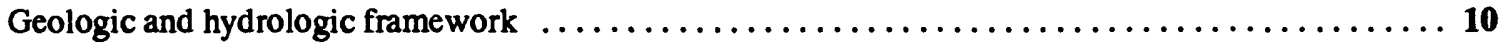

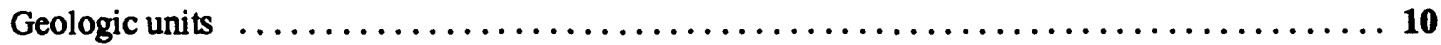

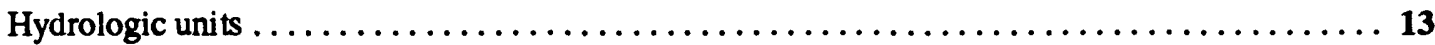

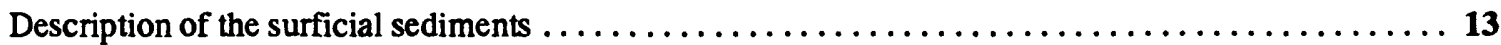

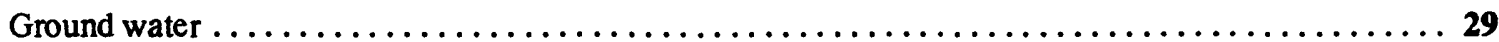

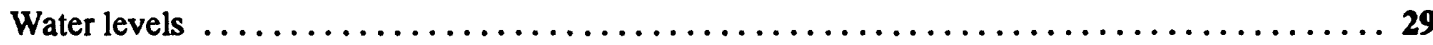

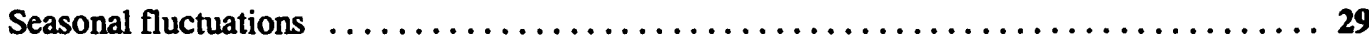

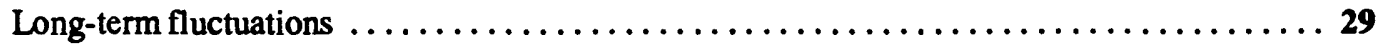

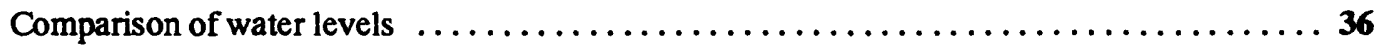

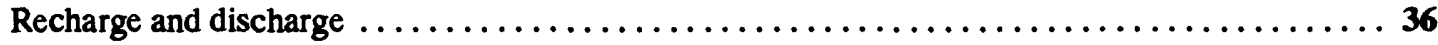

Recharge and discharge areas $\ldots \ldots \ldots \ldots \ldots \ldots \ldots \ldots \ldots \ldots \ldots \ldots \ldots \ldots \ldots \ldots \ldots \ldots \ldots$

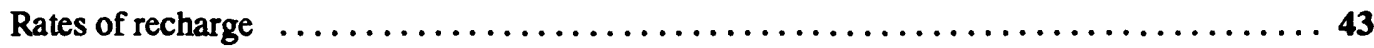

Hydraulic characteristics of the surficial aquifer system $\ldots \ldots \ldots \ldots \ldots \ldots \ldots \ldots \ldots$

Laboratory determinations of hydraulic conductivity $\ldots \ldots \ldots \ldots \ldots \ldots \ldots \ldots$

Field determinations of hydraulic conductivity $\ldots \ldots \ldots \ldots \ldots \ldots \ldots \ldots \ldots \ldots \ldots$

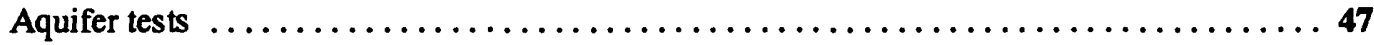

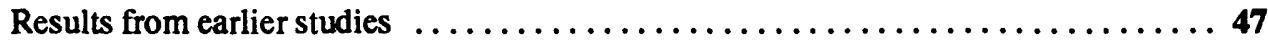

Oak Hill aquifer test $\ldots \ldots \ldots \ldots \ldots \ldots \ldots \ldots \ldots \ldots \ldots \ldots \ldots \ldots \ldots \ldots \ldots$

Quality of water . . . . . . . . . . . . . . . . . . . . . . . . . . . . 49

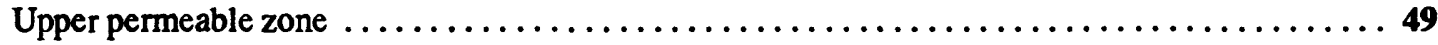

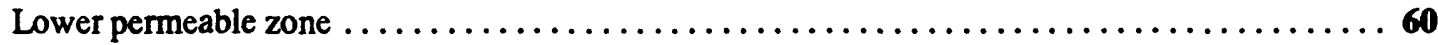

Summary of water quality from both zones $\ldots \ldots \ldots \ldots \ldots \ldots \ldots \ldots \ldots \ldots \ldots \ldots \ldots \ldots \ldots \ldots$

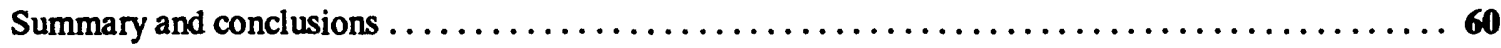

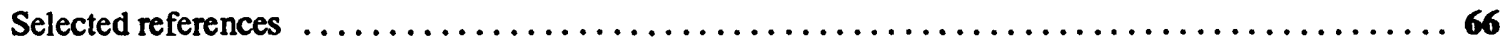

\section{FIGURES}

Figure 1-7. Maps showing:

1. Location of major political boundaries and drainage features in Volusia County . . . . . . . 2

2. Major physiographic features of Volusia County $\ldots \ldots \ldots \ldots \ldots \ldots \ldots \ldots \ldots$ 


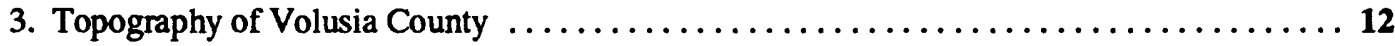

4. Altitude of top of Floridan aquifer system $\ldots \ldots \ldots \ldots \ldots \ldots \ldots \ldots \ldots \ldots \ldots \ldots \ldots \ldots \ldots$

5. Locations of test wells drilled, core holes, and St. Johns River Water

Management District wells .................................... 15

6. Thickness of sediments overlying the Floridan aquifer system $\ldots \ldots \ldots \ldots \ldots \ldots \ldots \ldots$

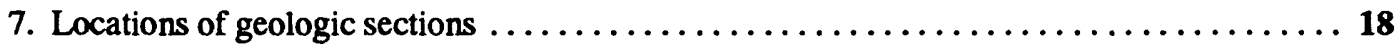

8a-8c. Geologic sections:

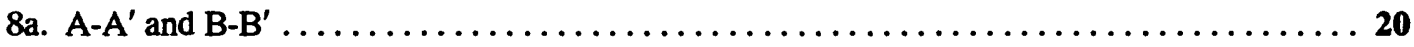

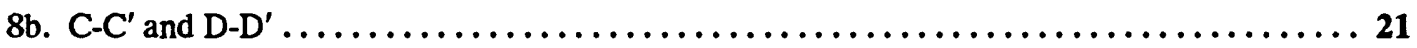

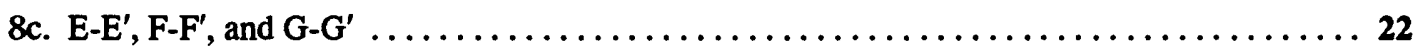

9a-9f. Natural gamma logs of test well pairs:

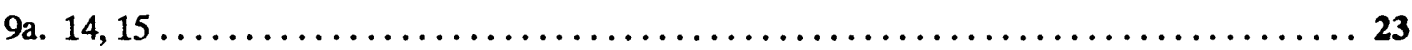

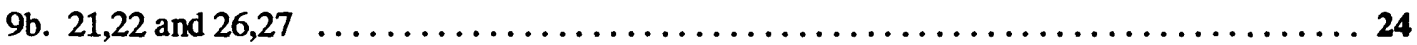

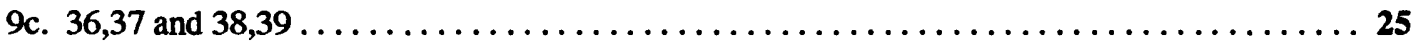

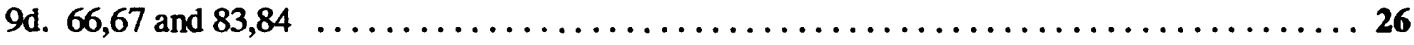

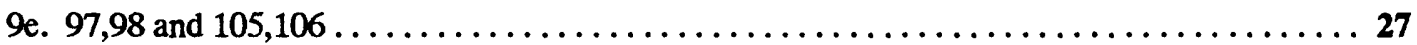

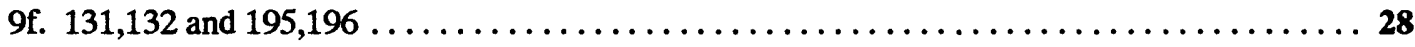

10-12. Maps showing:

10. Water levels in wells completed in the upper permeable zone of the surficial aquifer system, February through May 1986, and potentiometric surface of the Upper

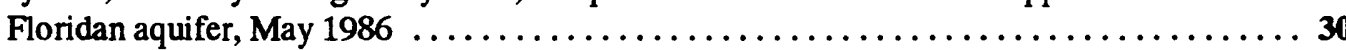

11. Water levels in wetls completed in the upper permeable zone of the surficial aquifer system and potentiometric surface of the Upper Floridan aquifer, September $1986 \ldots \ldots \ldots \ldots \ldots 31$

12. Locations of wells with hydrograph records longer than 2 years $\ldots \ldots \ldots \ldots \ldots \ldots \ldots . \ldots 37$

13a-13b. Hydrographs for wells 143 and 164 completed in the upper permeable zone:

13a. And rainfall at De Land, May 1985 through May $1987 \ldots \ldots \ldots \ldots \ldots \ldots \ldots \ldots$

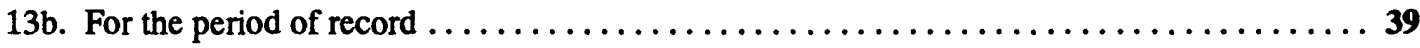

14-15. Maps showing:

14. Relation of the potentiometric surface of the Upper Floridan aquifer to land surface ..... 41

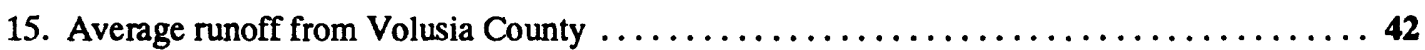

16. Graph showing calculation of recharge using the hydrograph of well $43 \ldots \ldots \ldots \ldots \ldots \ldots \ldots 45$

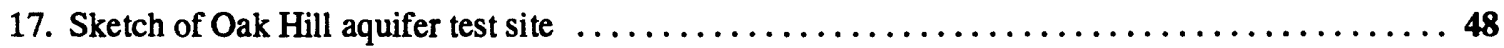

18a-18b. Graphs showing:

18a. Time-drawdown plot for Oak Hill observation wells $\ldots \ldots \ldots \ldots \ldots \ldots \ldots \ldots \ldots \ldots, 50$

18b. Calculation of transmissivity of the lower permeable zone at Oak Hill $\ldots \ldots \ldots \ldots \ldots \ldots 51$

19-20. Maps showing:

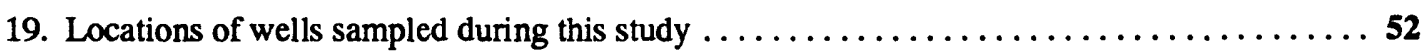

20. Distribution of chloride concentration in water from the upper permeable zone and

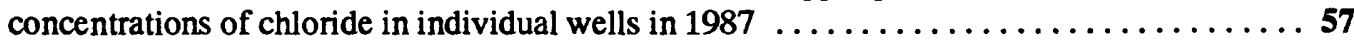

21-23. Diagrams showing:

21. Chemical composition of water in the upper permeable zone $\ldots \ldots \ldots \ldots \ldots \ldots \ldots \ldots, 59$

22. Chemical composition of water in the lower permeable zone $\ldots \ldots \ldots \ldots \ldots \ldots \ldots \ldots 63$

23. Major ion concentrations of water from selected wells $\ldots \ldots \ldots \ldots \ldots \ldots \ldots \ldots \ldots \ldots$ 


\section{TABLES}

1. Inventory of selected wells completed in the surficial aquifer system $\ldots \ldots \ldots \ldots \ldots \ldots \ldots .4$

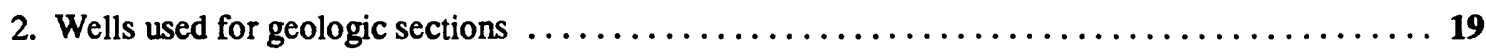

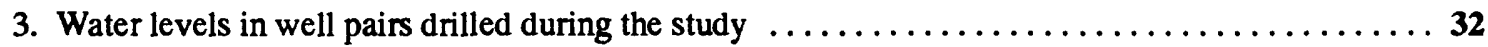

4. Comparison of water levels in the surficial aquifer system and the Upper Floridan

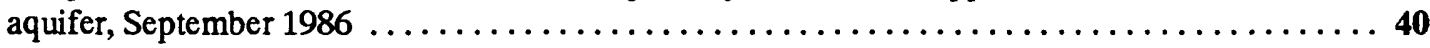

5. Laboratory hydraulic conductivities for selected core samples in Volusia County $\ldots \ldots \ldots \ldots .46$

6. Field hydraulic conductivities for wells in Volusia County $\ldots \ldots \ldots \ldots \ldots \ldots \ldots \ldots \ldots \ldots$

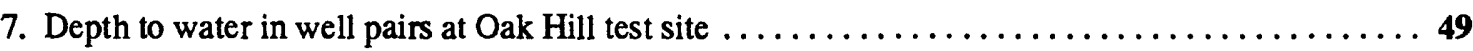

8. Physical and chemical characteristics of water from the upper permeable zone $\ldots \ldots \ldots \ldots \ldots 53$

9. Nutrient concentrations in water from the upper permeable zone $\ldots \ldots \ldots \ldots \ldots \ldots \ldots \ldots . \ldots 6$

10. Physical and chemical characteristics of water from the lower permeable zone $\ldots \ldots \ldots \ldots \ldots 61$

11. Nutrient concentrations in water from the lower permeable zone $\ldots \ldots \ldots \ldots \ldots \ldots \ldots \ldots 6$

12. Statistical summary for physical and chemical characteristics of water from the upper and lower permeable zones of the surficial aquifer system, Volusia County $\ldots \ldots \ldots 64$ 


\section{CONVERSION FACTORS AND ABBREVIATIONS}

The inch-pound units used in this report may be converted to metric (International System) units by the following factors.

\begin{tabular}{|c|c|c|}
\hline Multiply inch-pound unit & By & To obtain metric unit \\
\hline \multicolumn{3}{|c|}{ Length } \\
\hline $\begin{array}{r}\text { inch (in.) } \\
\text { foot (ft) } \\
\text { mile (mi) }\end{array}$ & $\begin{array}{l}25.4 \\
0.3048 \\
1.609\end{array}$ & $\begin{array}{l}\text { millimeter }(\mathrm{mm}) \\
\text { meter }(\mathrm{m}) \\
\text { kilometer }(\mathrm{km})\end{array}$ \\
\hline \multicolumn{3}{|c|}{ Area } \\
\hline square mile $\left(\mathrm{mi}^{2}\right)$ & 2.590 & square kilometer $\left(\mathrm{km}^{2}\right)$ \\
\hline \multicolumn{3}{|c|}{ Flow } \\
\hline $\begin{array}{r}\text { gallon per minute } \\
\text { (gal/min) }\end{array}$ & 0.06309 & liter per second (L/s) \\
\hline $\begin{array}{r}\text { million gallons per day } \\
(\mathrm{Mgal} / \mathrm{d})\end{array}$ & 0.04381 & $\begin{array}{l}\text { cubic meter per second } \\
\left(\mathrm{m}^{3} / \mathrm{s}\right)\end{array}$ \\
\hline inch per year (in/yr) & 25.4 & millimeter per year $(\mathrm{mm} / \mathrm{yr})$ \\
\hline \multicolumn{3}{|c|}{ Transmissivity } \\
\hline foot squared per day ( $\left.\mathrm{ft}^{2} / \mathrm{d}\right)$ & 0.0929 & meter squared per day $\left(\mathrm{m}^{2} / \mathrm{d}\right)$ \\
\hline \multicolumn{3}{|c|}{ Hydraulic conductivity } \\
\hline foot per day $(\mathrm{ft} / \mathrm{d})$ & 0.3048 & meter per day $(\mathrm{m} / \mathrm{d})$ \\
\hline
\end{tabular}

Equations for temperature conversion between degrees Celsius $\left({ }^{\circ} \mathrm{C}\right)$ and degrees Fahrenheit $\left({ }^{\circ} \mathrm{F}\right)$ :

$$
\begin{aligned}
& { }^{\circ} \mathrm{C}=5 / 9\left({ }^{\circ} \mathrm{F}-32\right) \\
& { }^{\circ} \mathrm{F}=\left(9 / 5^{\circ} \mathrm{C}\right)+32
\end{aligned}
$$

Chemical concentrations are given in micrograms per liter $(\mu \mathrm{g} / \mathrm{L})$ and in milligrams per liter $(\mathrm{mg} / \mathrm{L})$.

Specific conductance is given in microsiemens per centimeter at 25 degrees Celsius $\left(\mu \mathrm{S} / \mathrm{cm}\right.$ at $25^{\circ} \mathrm{C}$ ); formerly termed micromhos per centimeter at 25 degrees Celsius $\left(\mu \mathrm{mho} / \mathrm{cm}\right.$ at $25^{\circ} \mathrm{C}$ ) in U.S. Geological Survey reports.

Sea level: In this report "sea level" refers to the National Geodetic Vertical Datum of 1929 (NGVD of 1929)--a geodetic datum derived from a general adjustment of the first-order level nets of both the United States and Canada, formerly called "Sea Level Datum of 1929."

Altitude, as used in this report, refers to distance above or below sea level. 


\title{
Geology, Hydrology, and Water Quality of the Surficial Aquifer System in Volusia County, Florida
}

\author{
By G.G. Phelps
}

\section{ABSTRACT}

The surficial aquifer system in Volusia County comprises Miocene to Holocene age sediments that overlie the Floridan aquifer system. The sediments consist of sand, sandy day, shell, and calcareous silty day, that together range in thickness from about 40 to more than 100 feet. Locally, the surficial aquifer system can be subdivided into upper and lower permeable zones separated by 5 to 10 feet of areally discontinuous day or silty sand.

Of the recorded 4,500 wells that tap the surficial aquifer system, more than 3,200 are used for irrigation and about 800 are used for domestic supply. Water use from the surficial aquifer system in 1987 totaled about 4.2 million gallons per day. The water level can be 30 feet or more below land surface in ridge areas, but is less than 10 feet below land surface on terraces and in the interridge area near the St. Johns River. In 1986, water levels in the upper permeable zone generally ranged 3 to 6 feet higher at the end of the wet season (fall) than in the dry season (spring). Water levels in wells tapping the lower permeable zone generally fluctuated less than 2 feet, except when influenced by pumping from the underlying Upper Floridan aquifer.

Recharge to and discharge from the surficial aquifer system is strongly influenced by heads in the undertying Upper Floridan aquifer. Important recharge areas are along the De Land Ridge and the western part of the Talbot Terrace; some recharge occurs along the Atlantic Coastal Ridge. The recharge rate in the ridge areas probably ranges from 9 to 18 inches per year, whereas in nonridge areas the rate is about 0 to 8 inches per year.

Reported laboratory hydraulic conductivities for surficial aquifer system core samples ranged from $7.6 \times 10^{-5}$ to $3.4 \times 10^{-1}$ feet per day with a median of $1.0 \times 10^{-2}$ feet per day, and reported field hydraulic conductivities ranged from $3.0 \times 10^{-2}$ to 12.8 feet per day with a median of $2.9 \times 10^{-1}$ feet per day. The transmissivity of the lower permeable zone in Oak Hill (southeastern Volusia County), calculated from an aquifer test, is 1,200 feet squared per day, and the corresponding hydraulic conductivity is about 30 feet per day. In the Oak Hill area, pumpage from the lower permeable zone is constrained by the potential for upconing of saltwater, rather than by the hydraulic properties of the aquifer.

Chloride concentrations of water from wells tapping the upper permeable zone ranged from 1.2 to 15,000 milligrams per liter; for the lower permeable zone, the range was from 5.7 to 340 milligrams per liter. In both zones, nutrient concentrations at some sites were higher than would be expected for natural ground water, indicating some effect from infiltrating surface water or human activity.

\section{INTRODUCTION}

Volusia County covers an area of about $1,200 \mathrm{mi}^{2}$ (square miles) in east-central Florida (fig. 1). Rapid population growth in the county has been spurred by increased tourism along the Atlantic Coast, by the growth of Oriando to the south (making some areas of south Volusia County a bedroom community of Orlando) and by a strong agricultural industry in the western and northwestern part of the county. The increase in population has also increased the demand for water for public and industrial supply, increased the need for development of areas that were once unpopulated, and increased the need for additional areas for disposal of municipal waste. These activities and demands either directly, or indirectly, affect the water resources of the county.

Previous hydrologic studies in the area focused almost entirely on the Floridan aquifer system, which is the main source of potable water in the county. The surficial aquifer system, which consists of the sediments overlying the Floridan, has not been studied in detail. The surficial aquifer system is not a major source of drinking water except in the southeastern part of the county. Its most important hydrologic function is to store and transmit water to and from the underlying Floridan aquifer system.

Information about the surficial aquifer system is needed to help county planners and environmental managers make informed decisions when evaluating plans for future development. To that end, the U.S. Geological Survey, in cooperation with Volusia County, conducted this study during 1985 through 1988 to provide geologic and hydrologic information on the surficial aquifer system.

\section{Purpose and Scope}

This report presents and interprets all the data collected during the hydrologic study of the surficial aquifer system of Volusia County in 1985-88. Because the study was of a reconnaissance nature and covered the entire county, the resulting interpretations are somewhat generalized. More detailed site-specific investigations may 


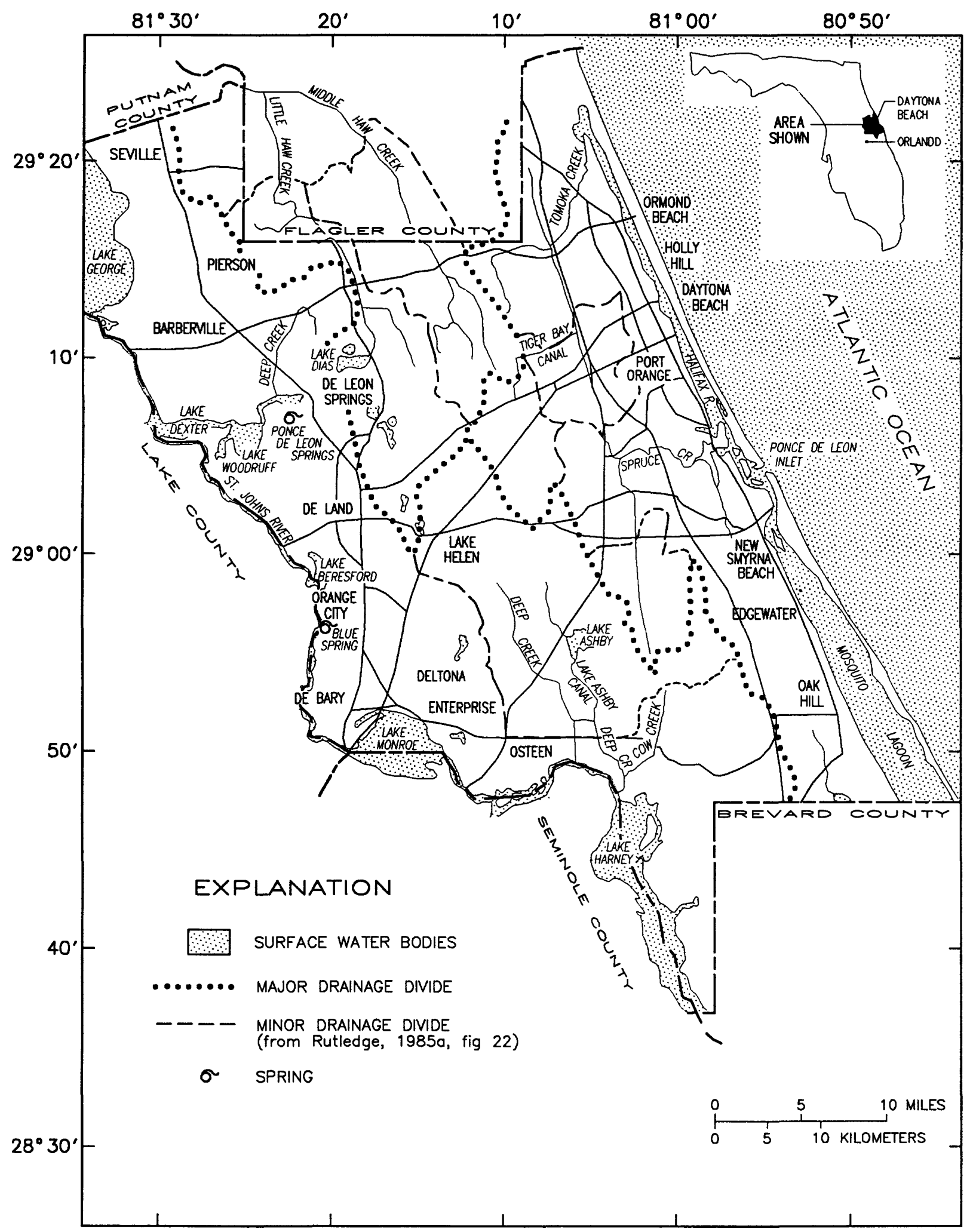

Figure 1. Location of major political and drainage features of Volusia County. 
be needed to evaluate local geohydrologic conditions and effects of development. This report is the first to define "background" conditions in the surficial aquifer system, and thus, may be useful for determining the types of data to be collected in future investigations.

This report includes the following types and formats of data and information:

\footnotetext{
1. Describes the lithology and thickness of the surficial aquifer system in Volusia County by using geologic sections, geophysical logs, and test drilling results;

2. Shows water levels in the surficial aquifer system using maps, hydrographs, and tabular data;

3. Describes the hydraulic characteristics of the surficial aquifer system at selected locations in the county as determined by field testing and laboratory analysis of cores;

4. Updates and refines the delineation of important recharge areas in the county based on the water-level information; and

5. Describes the water-quality characteristics of the surficial aquifer system through chemical analyses of water from $\mathbf{5 2}$ wells.
}

\section{Previous Investigations}

Early reconnaissances of the ground-water resources of Volusia County were done by Wyrick and Leutze (1956), and Wyrick $(1960,1961)$. These studies included well inventories, results of test drilling, aquifer testing of the Upper Floridan aquifer, and ground-water sampling for chloride concentration. Knochenmus (1968), and Knochenmus and Beard (1971) studied both the groundwater and surface-water features of Volusia County, and their reports include major-ion analyses of water from two wells that tap the surficial aquifer system. Bush (1978) made computer simulations of ground-water flow in the Upper Floridan aquifer in part of central Volusia County, and Simonds and others (1980) used areal photographs, together with field observations, to correlate fluctuations of the water table in the area with vegetation type. Rutledge (1985b) analyzed a long-term aquifer test done in central Volusia County. Other work by Rutledge $(1982,1985 a)$ includes a detailed study of the hydrology of the northwestem part of the county and a countywide study emphasizing the occurrence of brackish water. Because the Floridan aquifer system is the major source of potable water in the county, it received the most emphasis in both of the investigations by Rutledge.

\section{Well Records and Well-Numbering System}

Records of wells in Volusia County are maintained by several government agencies. The U.S. Geological Survey and the St. Johns River Water Management District have computerized data bases and paper files on well records that contain geologic, hydrologic, water-level, geophysical-log, water-quality, and water-use data. The U.S. Geological Survey assigns a unique 15-digit site identification number to each well inventoried. The first 13 digits of the number denote the latitude and longitude of the well, and the last two digits denote a sequential number for wells located in the same 1-second latitude by 1-second longitude block. For example, well 291007081101613 is the 13 well inventoried at latitude $29^{\circ} 10^{\prime} 07^{\prime \prime} \mathrm{N}$. and longitude $81^{\circ} 10^{\prime} 16^{\prime \prime} \mathrm{W}$. In some instances, the site identification number may not be identical to the actual latitude and longitude location of the well.

The Florida Geological Survey keeps records of geologic data for wells throughout the State including more than 400 wells in Volusia County. Some well records are for the surficial aquifer system, but most are for the Floridan aquifer system.

The Volusia County Building Inspection Department maintains a data file called VOLDATA that includes all wells permitted by that department since 1976 . That file contains useful information about the rate wells are being drilled, the uses of new wells, and when added to historic data, the total number of wells in the county. In June 1988, the VOLDATA file contained information on 12,314 wells, of which about 4,500 tap the surficial aquifer system. More than 3,200 wells (primarily in the eastern part of the county) are used for irrigation, mostly for lawns and gardens. About 800 wells are used for domestic supply. Most domestic wells that tap the surficial aquifer system are in the southeastern part of the county (Rutledge, 1985a, figs. 7 and 8).

Table 1 contains information from the files of the U.S. Geological Survey on selected wells tapping the surficial aquifer system. Included in this table are the types of data collected during this study and a well number for ease of reference to wells without using the complete U.S. Geological Survey site identification number.

\section{Water Use}

Total water use from the surficial aquifer system in 1980 was estimated by Rutledge (1985a, p. 16) to be about $3 \mathrm{Mgal} / \mathrm{d}$ (million gallons per day). Updated water-use estimates for 1987 were calculated using data collected by the St. Johns River Water Management District in 1985 (Marella, 1986). Because 16 percent of the domestic wells in the VOLDATA file tap the surficial aquifer system, the total domestic self-supplied water use from Marella (1986, table 2), $5.32 \mathrm{Mgal} / \mathrm{d}$, was multiplied by 0.16 to obtain an estimate of $0.85 \mathrm{Mgal} / \mathrm{d}$ for domestic water use from the surficial system. Information in VOLDATA is inconclusive on the percentage of surficial aquifer wells used for air conditioning cooling water, so it was assumed that about 16 percent of the wells (the same percentage as for domestic self-supplied wells) were used for air conditioning. Marella (1986, p. 16) reports a total of $6.23 \mathrm{Mgal} / \mathrm{d}$ used for air conditioning in Volusia County, so 16 percent of that number is about $1 \mathrm{Mgal} / \mathrm{d}$. 
Table 1. Inventory of selected wells completed in the surficial aquifer system

[Data collected: G, geophysical log; S, water sample analyzed; W, water level measured; and --, no data]

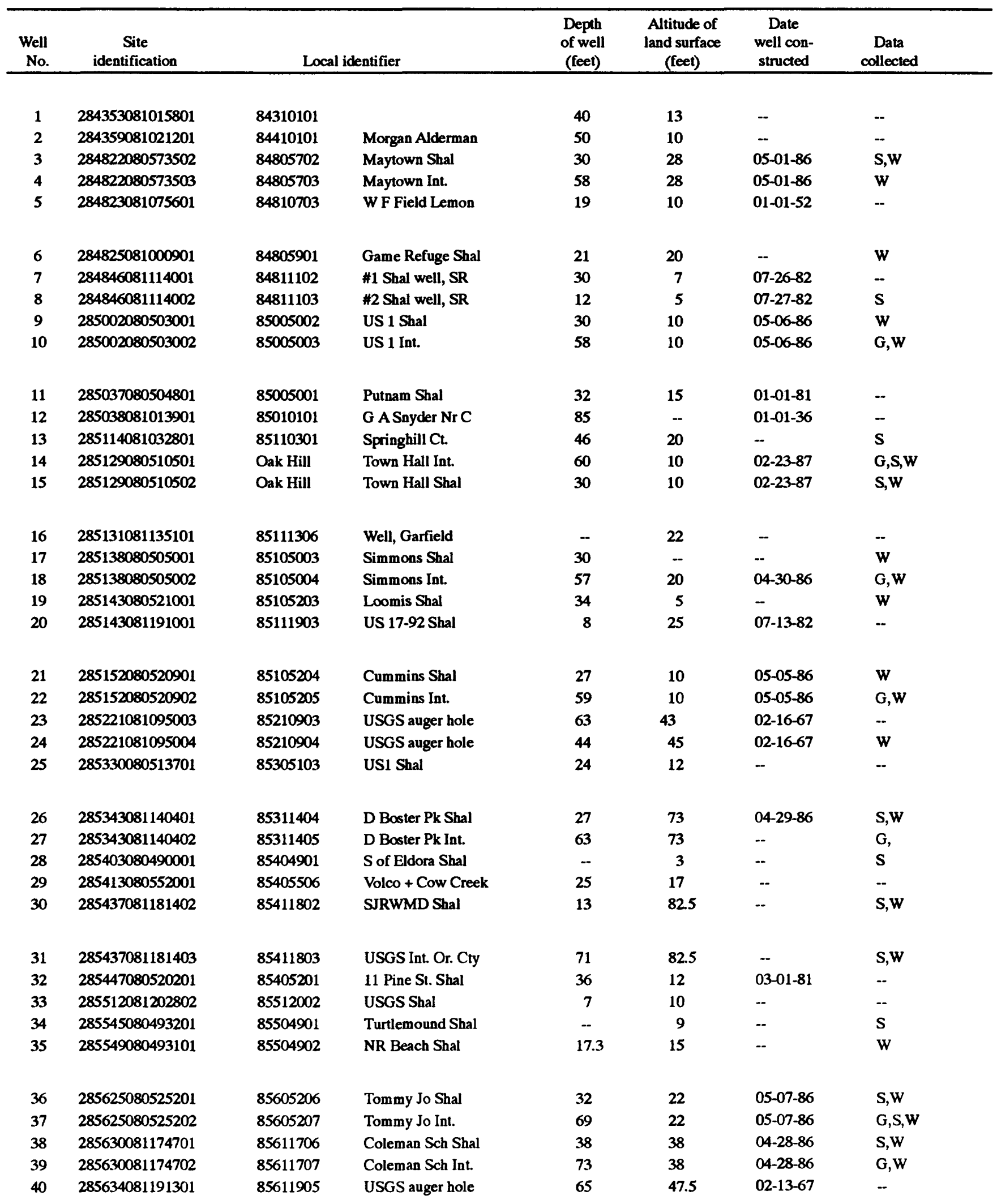


Table 1. Inventory of selected wells completed in the surficial aquifer system - Continued

[Data collected: G, geophysical log; S, water sample analyzed; W, water level measured; and --, no data]

\begin{tabular}{ccccccc}
\hline Well & Site & Depth & Altitude of & Date & \\
well con- & Data \\
No. & identification & Local identifier & $\begin{array}{c}\text { of well } \\
\text { (feet) }\end{array}$ & $\begin{array}{c}\text { land surface } \\
\text { (feet) }\end{array}$ & $\begin{array}{c}\text { structed } \\
\text { collected }\end{array}$ \\
\hline
\end{tabular}

$\begin{array}{llll}41 & 285634081191302 & 85611903 & \text { USGS auger hole } \\ 42 & 285634081191303 & 85611904 & \text { USGS auger hole } \\ 43 & 285643081122602 & 85611202 & \text { USGS Test well } \\ 44 & 285655081165602 & 85611602 & \text { USGS Test well } \\ 45 & 285704080502801 & 85705004 & \text { Cedar Cr. Resort }\end{array}$

$\begin{array}{lcc}56 & 47.1 & 02-14-67 \\ 35 & 48.4 & 02-14-67 \\ 37 & 36.4 & 01-01-65 \\ 32 & 19.8 & 01-01-65 \\ 29 & 5 & 12-01-80\end{array}$

S, w

$\begin{array}{llll}46 & 285715080504001 & 85705005 & \text { River + Grunion } \\ 47 & 285742080533201 & 85705301 & \text { Denson Dr. Shal } \\ 48 & 285757081174301 & 85711701 & \text { N Thorpe Shal } \\ 49 & 285825080535601 & 85805301 & \text { Hill St. Shal W } \\ 50 & 285834081044301 & 85810401 & \text { Rasley + SR 415 }\end{array}$

85811202

85811304

85911901

85911902

85905505

285902080551101

285904081152602

285904081152604

285904081152605

285904081164701

285904081171101

$61 \quad 285904081171102$

$62 \quad 285904081171103$

$63 \quad 285916080520301$

$64 \quad 285940080575601$

$65 \quad 290006080544101$

$66 \quad 290025081185001$

$67 \quad 290025081185002$

$68 \quad 290026080580201$

$69 \quad 290029081223601$

$70 \quad 290056081210801$

$71 \quad 290106081132103$

$72 \quad 290107081062002$

$73 \quad 290114081121602$

74290117081183501

$75 \quad 290132081085401$

$76 \quad 290132081112601$

$77 \quad 290134080554201$

$78 \quad 290147080534701$

$79 \quad 290155080560301$

$80 \quad 290159081130002$

$\begin{array}{ll}85911502 & \text { USGS Test well } \\ 85911505 & \text { USGS auger hole } \\ 85911506 & \text { USGS auger hole } \\ 85911601 & \text { USGS auger hole } \\ 85911704 & \text { USGS auger hole }\end{array}$

85911706

85911705

85905201

85905713

90005403

90011801

90011802

90005801

90012205

90111303

90110603

90111202

90111803

90110801

90111101

90105516

90105302

90105612

90111305

RR Track Shal
90012109
USGS auger hole USGS auger hole 4619 Katy Dr. S 1460 Glencoe Shal 116 Shal

SW7 GR Shal SW7 GR Int.

71 P Shal

Old S Shal

USGS Test well

USGS Test well

17S31E16 USGS

Euclid Ave Sch

USGS Core well

17S31E15 131

$318 \mathrm{~N}$ Shal

806 S Shal

Edward St. Shal

USGS Test well

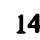

25

38

29

15

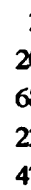

20

68

22

47

50.4
69
30
30
10

78.4

78.6

78.7

60.5

33.5

05-01-81

10-01-80

04-28-86

09-01-80

$-$

02-24-67

04-23-86

02-15-67

02-16-67

02-01-81

01-01-65 02-10-67 02-20-67

02-20-67

02-14-67

64

32

96

20

25

39

36

64

26

7

16

33
33.5
15
30
7

02-14-67

02-23-67

06-01-81

03-01-81

--

68
68
20
5
25

04-23-86

04-23-86

02-01-81

07-09-82

07-13-82

S,W

G,S,W

-

S, w

47

$47 \quad 39.3$

01-01-65

01-01-65

08-22-67

04-24-86

43

40

--

$\begin{array}{cc}4.1 & 37 \\ 18 & 7 \\ 26 & 10 \\ 16 & 7 \\ 36 & 37.6\end{array}$

03-01-77

07-01-81

11-01-80

07-01-81

08-15-67

w

$-$

S

$-$

$\mathrm{S}, \mathrm{W}$

--

--

$-$

$\cdots$

$-$

$-$

S

W, W

w

w

$\bar{w}$

w

$-$ 
Table 1. Inventory of selected wells completed in the surficial aquifer system-Continued

[Data collected: G, geophysical log; S, water sample analyzed; W, water level measured; and --, no data]

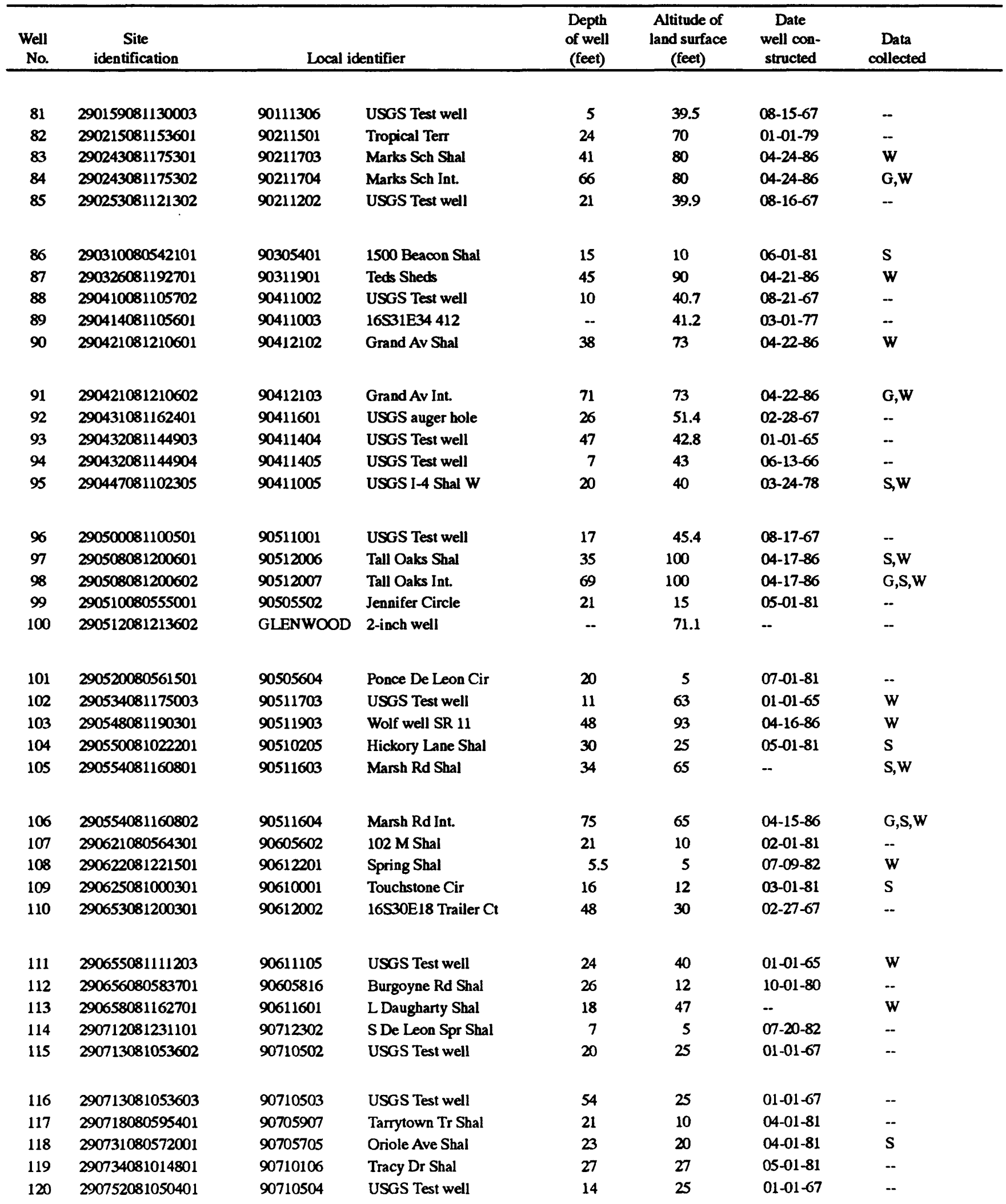


Table 1. Inventory of selected wells completed in the surficial aquifer system-Continued

[Data collected: G, geophysical log; S, water sample analyzed; W, water level measured; and --, no data]

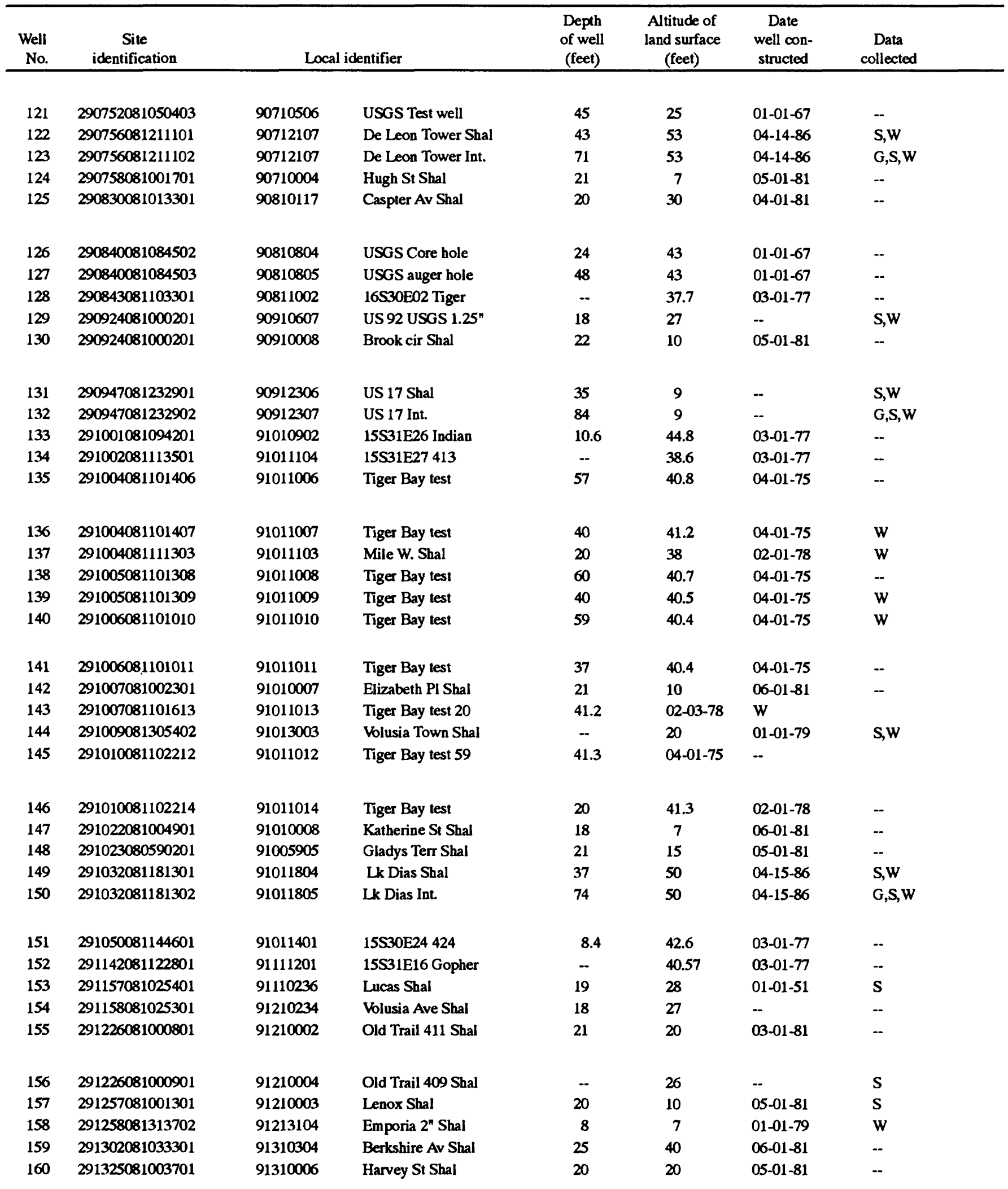


Table 1. Inventory of selected wells completed in the surficial aquifer system - Continued

[Data collected: G, geophysical log; S, water sample analyzed; W, water level measured; and --, no data]

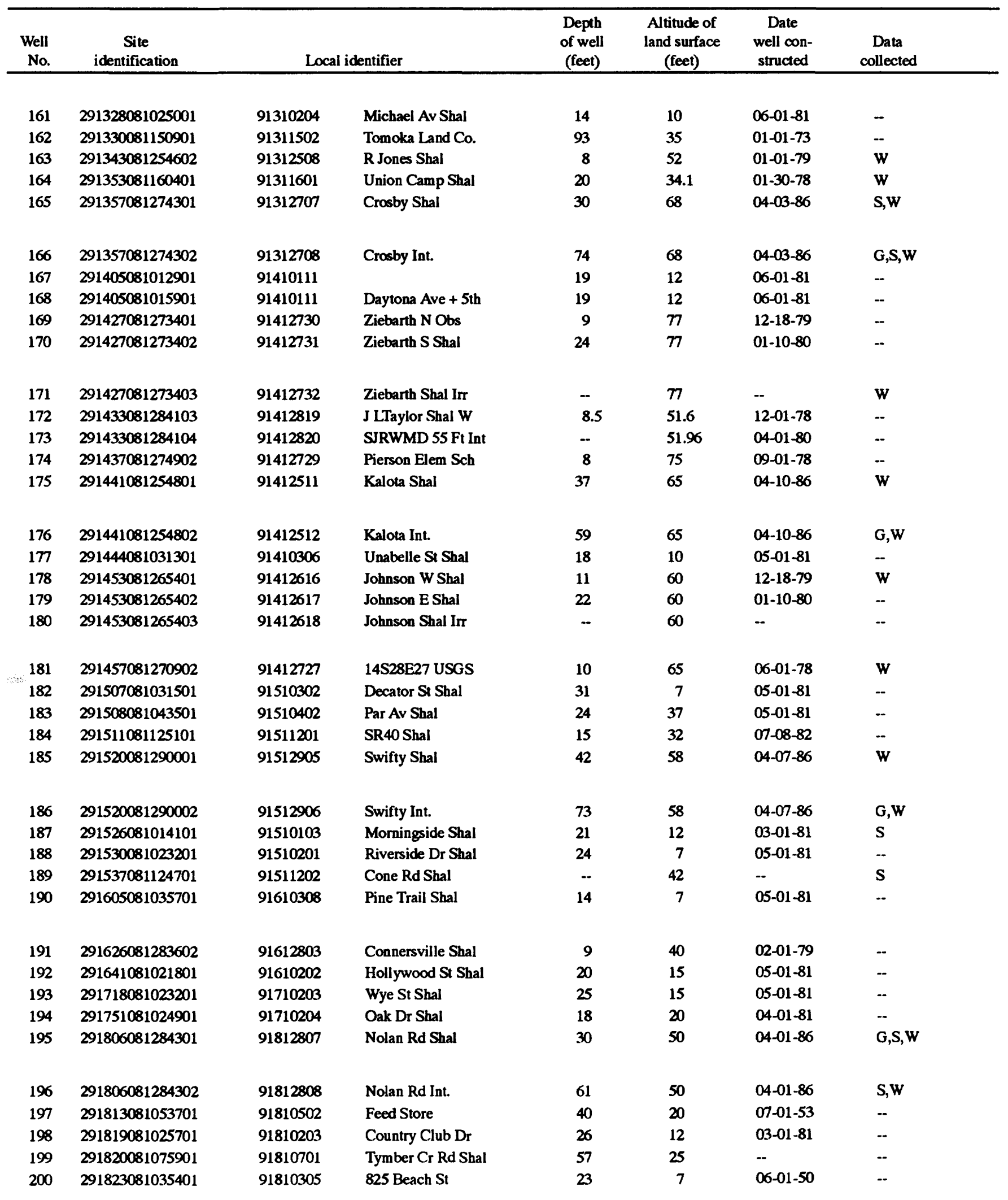


Table 1. Inventory of selected wells completed in the surficial aquifer system-Continued

[Data collected: G, geophysical log; S, water sample analyzed; W, water level measured; and --, no data]

\begin{tabular}{|c|c|c|c|c|c|c|c|}
\hline $\begin{array}{l}\text { Well } \\
\mathrm{Na}\end{array}$ & $\begin{array}{c}\text { Sile } \\
\text { identification }\end{array}$ & Loc & Entifier & $\begin{array}{l}\text { Depth } \\
\text { of well } \\
\text { (feet) }\end{array}$ & $\begin{array}{l}\text { Altitude of } \\
\text { land surface } \\
\text { (feel) }\end{array}$ & $\begin{array}{l}\text { Date } \\
\text { well con- } \\
\text { structed }\end{array}$ & $\begin{array}{l}\text { Data } \\
\text { collected }\end{array}$ \\
\hline 201 & 291842081060901 & 91810604 & Nursery Shal & 41 & 25 & 03-01-81 & -. \\
\hline 202 & 291846081031301 & 91810308 & Ormwood Dr Shal & 21 & 25 & $03-01-81$ & .- \\
\hline 203 & 291906081033201 & 91910314 & 60 River Dr & 17 & 12 & $12-01-54$ & -. \\
\hline 204 & 291907081031801 & 91910315 & 13 River $\mathrm{Dt}$ & 19 & 10 & $01-01-54$ & .. \\
\hline 205 & 291910081033001 & 91910310 & 47 Brooks Dr & - & 12 & $01-01.52$ & -- \\
\hline 206 & 291933081294501 & 91912005 & Seville Fire Tower & 31 & so & $03-31-86$ & $w$ \\
\hline 207 & 291936081035401 & 91910305 & Palm + J Anderson & 16 & 5 & $03-01-53$ & -. \\
\hline 2008 & 291951081072601 & 91910703 & NG 11 & 75 & 33 & .. & $\mathbf{w}$ \\
\hline 209 & 291959081074301 & 92010701 & Old Post Oftice & 14 & 32 & $01-01-30$ & -- \\
\hline 210 & 292027081073501 & 92010703 & National Garden & 75 & 30 & $-\cdot$ & .. \\
\hline 211 & 292020081073502 & 92010704 & National Garden & 15 & 30 & -. & .. \\
\hline 212 & 292028081080202 & 92010805 & NG 25 & 49 & 30 & -- & w \\
\hline 213 & 292041081075501 & 92010701 & NG 6 & 66 & 28 & -. & $w$ \\
\hline 214 & 292056081080201 & 92010806 & NG 5A & 65 & 30 & - & $\mathbf{S , w}$ \\
\hline 215 & 292056081080202 & 92010807 & NG 5B & 15 & 30 & - & $\mathbf{s , w}$ \\
\hline 216 & 292059081041401 & 92010403 & Morningstar Av & 14 & 10 & $05-01-81$ & - \\
\hline 217 & 292059081055002 & 92010515 & NG 125 & 20 & 3 & - & $w$ \\
\hline 218 & 292105081073101 & 92110706 & National Garden & 30 & 32 & - & - \\
\hline 219 & 292121081041901 & 92110404 & San Joee Dr Shal & 18 & 5 & $06-01-81$ & $\mathbf{s}$ \\
\hline 220 & 292129081073701 & 92110705 & National Garden & 65 & 32 & - & .. \\
\hline 221 & 292147081044401 & 92110401 & Dug Well on J A & 14 & 10 & $01-01-23$ & $w$ \\
\hline 222 & 292151081073301 & 92110701 & NG $4 A$ & 60 & 33 & - & $\mathbf{w}$ \\
\hline 223 & 292151081073302 & 92110702 & NG 4B & 23 & 33 & -- & - \\
\hline 224 & 292154081075701 & 92110703 & National Garden & 65 & 28 & - & .. \\
\hline 225 & 292216081075401 & 92210702 & Halifax Plantation & 58 & 30 & -- & - \\
\hline 226 & 202252081083602 & 92210802 & Halifax Plantation & 70 & 32 & -- & -. \\
\hline 227 & 292258031065001 & 92210601 & HP 11 & 18 & 3 & - & $w$ \\
\hline 228 & 292304081071901 & 92310707 & HP 14 & 18 & 5 & - & $\mathbf{s , w}$ \\
\hline 229 & 292309081082701 & 92310802 & Halifax Plantation & 65 & 32 & -. & - \\
\hline 230 & 292311081075801 & 92310705 & HP 13 & 51 & 25 & - & $\mathbf{w}$ \\
\hline 231 & 292318081075701 & 92310706 & HP 36 & 49 & 20 & -- & $\mathbf{s , w}$ \\
\hline 232 & 292323081083201 & 92310803 & Halifax Plantation & 23 & 30 & - & - \\
\hline 233 & 292325081080301 & 92310608 & Halifax Plantation & 15 & 24 & .. & -. \\
\hline 234 & 292346081084001 & 92310805 & Halifax Plantation & 23 & 32 & -. & -. \\
\hline 235 & 292347081080901 & 92310807 & Halifax Plantation & 23 & 22 & .. & -. \\
\hline 236 & 292359081084501 & 92310806 & Halifax Plantation & 23 & 32 & - & .. \\
\hline 237 & 292409081085001 & 92410803 & Halifax Plantation & 23 & 30 & - & - \\
\hline 238 & 292410081081701 & 92410806 & Halifax Plantation & 45 & 22 & -. & -- \\
\hline 239 & 292412081083801 & 92410804 & Halifax Plantation & 23 & 32 & - & -. \\
\hline 240 & 292421081072302 & 92410702 & Halifax Plantation & 13 & 6 & -. & -. \\
\hline 241 & $29242808108520 \mathrm{~J}$ & 92410805 & Halifax Plantation & 45 & 30 & .. & -- \\
\hline
\end{tabular}


The major use of water from the surficial aquifer system is for lawn irrigation, which was $2 \mathrm{Mgal} / \mathrm{d}$ in 1980 (Rutledge, 1985a, p. 16). The rate of use for 1987 was estimated by multiplying the 1980 rate by the percentage increase in other categories of water use in Volusia County between 1980 and 1985. Public supply use increased by 17 percent and domestic self supply increased by 15 percent (Rutledge, 1985a, table 2; Marella, 1986, tables 1 and 2), so a 15 percent increase in lawn irrigation was assumed.

Total use of water, in million gallons per day, from the surficial aquifer system in 1987 was thus estimated to be:

$\begin{array}{lc} & \text { Mgald } \\ \text { Domestic self supplied } & 0.9 \\ \text { Air conditioning } & 1.0 \\ \text { Lawn irrigation } & \underline{2.3} \\ \text { Total } & \overline{4.2}\end{array}$

\section{ENVIRONMENTAL SETTING}

\section{Climate}

The climate of Volusia County is humid subtropical. The average annual temperature is $70.4^{\circ} \mathrm{F}$ at $\mathrm{De}$ Land and $70.3^{\circ} \mathrm{F}$ at Daytona Beach. Average annual rainfall is 54.57 inches at De Land and 48.46 inches at Daytona Beach. The rainy season occurs from June through Seplember when about half of the total annual precipitation falls. During the summer, convection thunderstorms can produce heavy but localized rainfall, resulting in several inches of precipitation falling in one location but perhaps little or none falling a few miles away.

Climate exerts a significant influence on the patterns of water use in Volusia County. For example, large amounts of water may be pumped from the Floridan aquifer system during the coldest months of winter to protect plants from freezing in the fern growing areas of northwestern Volusia County. The heavy pumping results in a sudden decline of water levels and concern about a potential increase in chloride concentration of the ground water. In the late winter and early spring, a large influx of tourists at the beaches causes a noticeable increase in ground-water use for municipal supply in eastern Volusia County.

\section{Physiography}

Two distinct physiographic features predominate in Volusia County--ridges and terraces (fig. 2)--which are relict shoreline features formed when sea level alternately fell and rose in response to the advances and retreats of Pleistocene glaciation within the last 2 million years (MacNeil, 1950). The Iluctuating sea level formed a series of shoreline features of ridges (beach dunes), scarps (shorelines), and terraces (the seafloor near shore).
The highest and oldest feature found in Volusia County is the De Land Ridge (figs. 2 and 3). White (1970) believes the ridge was part of the Wicomico Shoreline formed during the Sangamon Interglaciation (which ended about 100,000 years ago) when the sea level was about 100 feet higher than it is at present. The next younger feature is the Talbot Terrace which occurs between altitudes of 25 and 50 feet above sea level. Rima Ridge, which separates the Talbot from the next younger terrace, the Pamlico, is 5 to 10 feet higher than the Talbot Terrace. The Pamlico Terrace ranges in altitude from 8 to $25 \mathrm{feet}$. In some places, the Atlantic Coastal Ridge, which separates the Pamlico and the youngest terrace, the Silver Bluff, is as much as $30 \mathrm{feet}$ higher than the Pamlico (Knochenmus, 1968). The Atlantic Beach Ridge barrier island is an active feature of the present-day sea level. Because the ridges are relatively high in altitude and are very permeable, they are frequently devoid of surface drainage.

The absence of surface drainage is particularly significant on the De Land Ridge because it has reinforced the development of karst on the ridge. Karst results when limestone is dissolved by water, resulting in an irregular land surface. Features of karst include lack of surface drainage, the presence of sinkholes, springs, round lakes, and, according to White (1970, p. 123-124), a wide variation in the altitude of contemporaneous relict shoreline features such as the Wicomico Shoreline. Surficial karst features are best developed on the De Land Ridge because it is the highest feature in the county and thus has not been repeatedly modified by sea inundations.

\section{GEOLOGIC AND HYDROLOGIC FRAMEWORK}

\section{Geologic Units}

The geologic units in Volusia County most relevant to this study were originally described by Wyrick (1960). The Oldsmar Formation, of early Eocene age, consists mostly of white limestone with thin beds of dolomite, and, in the lower part, beds of gypsum and anhydrite. In Volusia County, the top of the Oldsmar is about 1,300 feet below sea level and thickness is about 500 feet (Miller, 1986, p. B22 and pls. 4 and 5). Above the Oldsmar lies the Avon Park Formation of middle Eocene age, which ranges in thickness in Volusia County from about 100 to 250 feet (Wyrick, 1960, fig. 12) and is known for its characteristic alternating layers of white, light gray, or light brown limestone and dark brown dolomite. Overlying the Avon Park is the Ocala Limestone of late Eocene age, which is composed of cream-to-white fossiliferous limestone. The surfaces of both the Ocala and the Avon Park are erosional, and because of extensive erosion, the Ocala Limestone is thin (less than $100 \mathrm{feet}$ ) in most of Volusia County, and absent on much of the De Land Ridge. These Eocene carbonates dip and thicken to the east. 


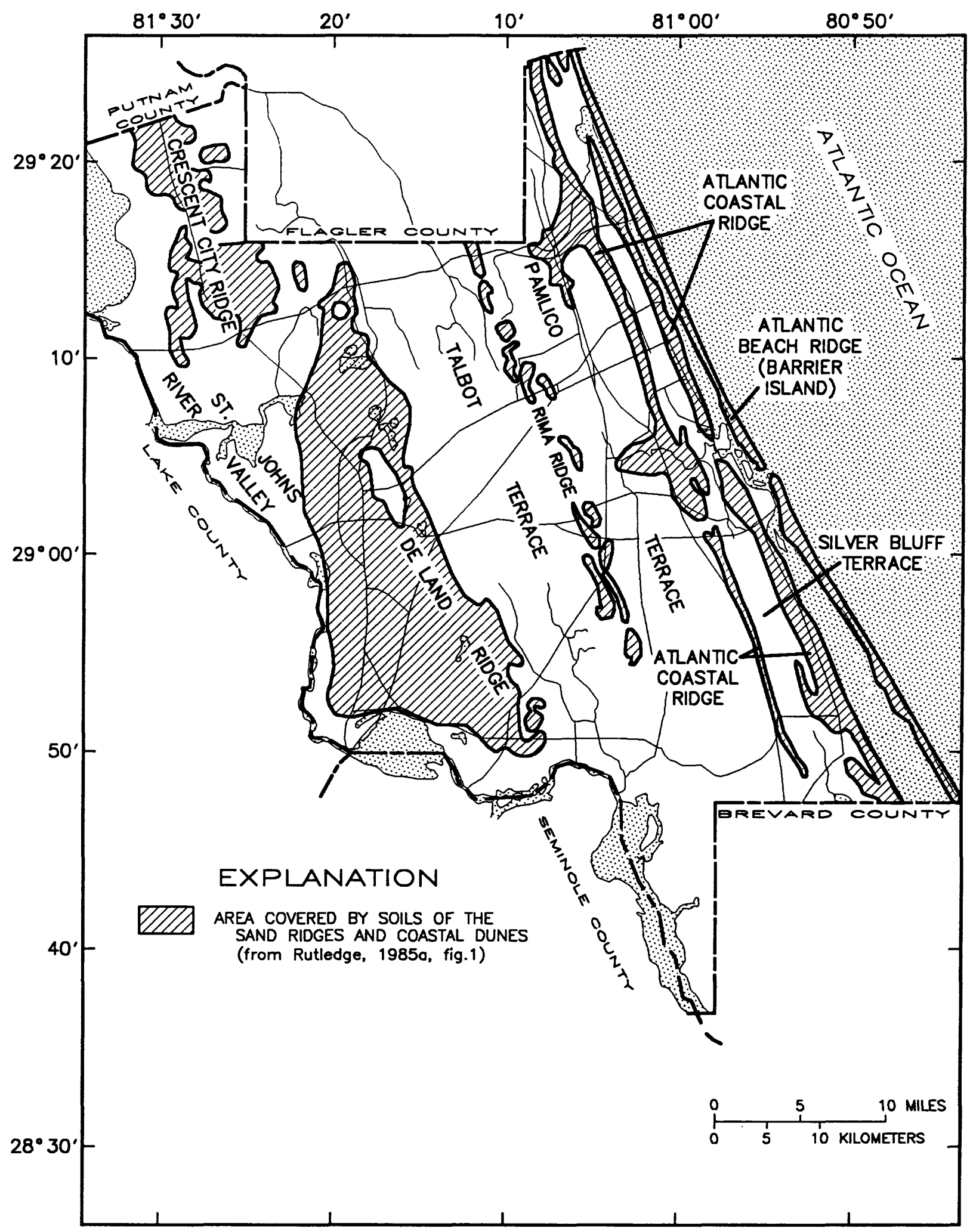

Figure 2. Major physiographic features of Volusia County. 


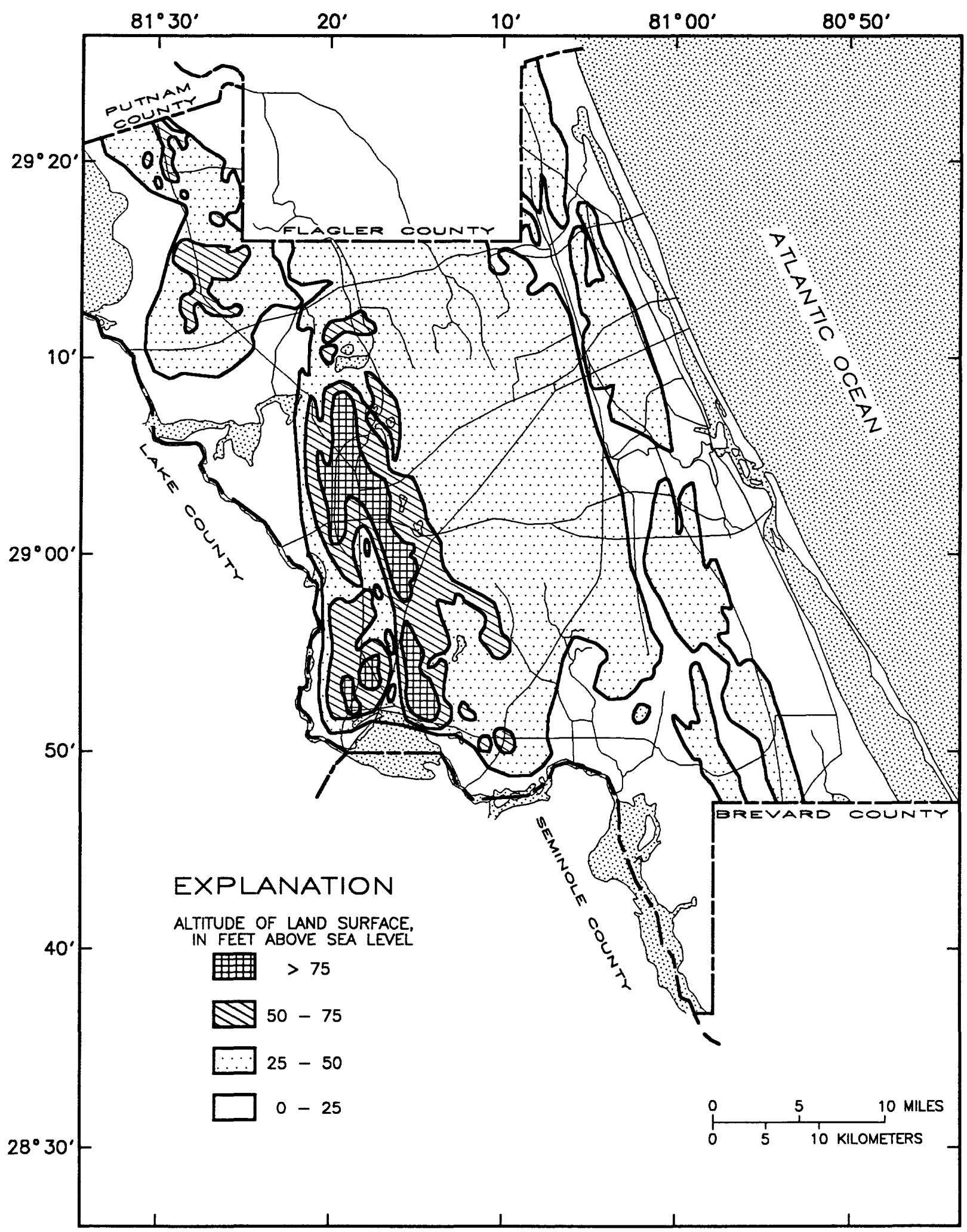

Figure 3. Topography of Volusia County (from Rutledge, 1985a, fig. 3). 
Overlying the marine carbonates are the Miocene and Pliocene deposits, consisting of unconsolidated beds of fineto medium-grained sand, shells, and silty calcareous clay. The Caloosahatchee Formation, thought by Cooke (1945, p. 214) to be Pliocene but more recently assigned to the Pleistocene by Brooks (1981), consists of beds of fine sand, shells, and calcareous silty clay. The middle Miocene-age Hawthom Formation is absent in much of Volusia County but has been tentatively identified in some wells in the western part of the county, based primarily on the presence of phosphate in well cuttings. However, it is possible that the phosphate results from later reworking of the Hawthorn Formation. The overall thickness of the Miocene or Pliocene deposits in Volusia County is about 20 to 50 feet.

The surficial sediments of Pleistocene to Holocene age consist of fine- to medium-grained quartz sand, sandy clay, and locally, beds of shell. In some areas, the sand has been cemented into "hardpan" by deposition of iron oxide at the water table. The Anastasia Formation, found in the eastern part of the county, consists primarily of coquina, which can vary from cemented and moderately hard to uncemented. This formation also contains varying amounts of quartz sand, silt and organic material (Toth, 1988, p. 46). The Pleistocene-to-Holocene deposits are generally 20 to 50 feet thick but locally can be as much as 100 feet thick.

\section{Hydrologic Units}

Three hydrologic units are present in Volusia County. They are (in the order in which they would be penetrated by a well): the surficial aquifer system, the intermediate confining unit, and the Floridan aquifer system. The surficial aquifer system in Volusia County is defined as comprising all of the water-yielding sediments overlying the Floridan aquifer system. These sediments occur at land surface and range in thickness from about 50 to 100 feet. In many areas of the county, the surficial aquifer system can be subdivided into an upper and a lower permeable zone which are separated by 5 to 10 feet of clay, or silty clay and sand. Although this poorly permeable layer was found at many sites, it is not believed to be areally continuous.

Underlying the surficial aquifer system in most of the county is an intermediate confining unit of clay or silty sand of Miocene age. The confining unit is leaky, but serves to confine water in the underlying Floridan aquifer system under artesian pressure (the water level in wells tapping the aquifer is above the top of the aquifer). The confining unit is thicker and more areally continuous in the eastern part of the county than in the west, where in some localities it is absent. In the central and western parts of the county, where the intermediate confining unit is apparently not continuous and mappable, the overlying sediments contain sufficient clay or silt to confine the Upper Floridan in all but a few areas on the De Land Ridge.

The Floridan aquifer system in Volusia County is composed of permeable beds of limestone and dolomite of the Oldsmar Formation and Avon Park Formation and, where present, the Ocala Limestone. The Floridan underlies all of Volusia County (and all of the Florida Peninsula) and is the main source of potable water in the county. In much of central Florida, the Floridan aquifer system can be divided into the Upper Floridan aquifer and the Lower Floridan aquifer, separated by a zone of lower permeability (Miller, 1986, p. B45). The transmissivity of the Upper Floridan aquifer in Volusia County (derived from computer modeling, flow net analyses, and a few aquifer tests) ranges from about 10,000 to $100,000 \mathrm{ft}^{2} / \mathrm{d}$ (feet squared per day) (Tibbals, 1981, fig. 6.). Along the Atlantic coast and along the valley of the St. Johns River, both the Upper Floridan and Lower Floridan aquifers contain salty water and are not used for water supply. In other parts of the county, the Upper Floridan aquifer contains freshwater, but the chloride concentration increases with depth. Most of the freshwater in the Upper Floridan in Volusia County is derived from recharge within the county. The altitude of the top of the Upper Floridan aquifer ranges from about 3 feet above sea level to more than 180 feet below sea level (both in west-central Volusia), and averages about 50 feet below sea level throughout most of the county (fig. 4) (Rutledge, 1985a, fig. 6).

\section{DESCRIPTION OF THE SURFICIAL SEDIMENTS}

During this study, 43 wells were drilled into the surficial sediments to provide lithologic, water-level, and water-quality data. At some sites, two wells were drilled, one about 30 feet deep and the other between 60 and 80 feet deep. Each well was given a number in table 1, but for simplicity in figure 5 only one well number of each pair is shown--usually it is the shallow well, but in one case it is the deep well. The locations of these wells, 14 core holes described by Kimrey (1990), and test wells studied by the St. Johns River Water Management District are shown in figure 5.

The thickness of the surficial sediments ranges from about 50 to 100 feet in most of Volusia County (fig. 6). In the extreme eastem part of the county, the thickness of sediments exceeds 100 feet in a few areas, and in the western part of the county, along the De Land Ridge and in the area of Deep Creek (fig. 1), the sediments may be as much as 175 feet thick. The surficial sediments near Orange City (fig. 1) exceed 200 feet in thickness.

Based on the data available, a general description of the surficial aquifer system is as follows: From land surface to about 30 feet in depth, the sediments are primarily sand with some shell and small amounts of silt. These sediments constitute the upper permeable zone of the surficial aquifer system. At most places, 5 to 10 feet of clay or clayey silt underlie the uppermost sand. The clay or silt layer within the surficial aquifer system is probably not continuous over the entire county in the same sense that the Floridan aquifer system is continuous, so no attempt was made to correlate it from one site to another. Below this clay or silt layer is 


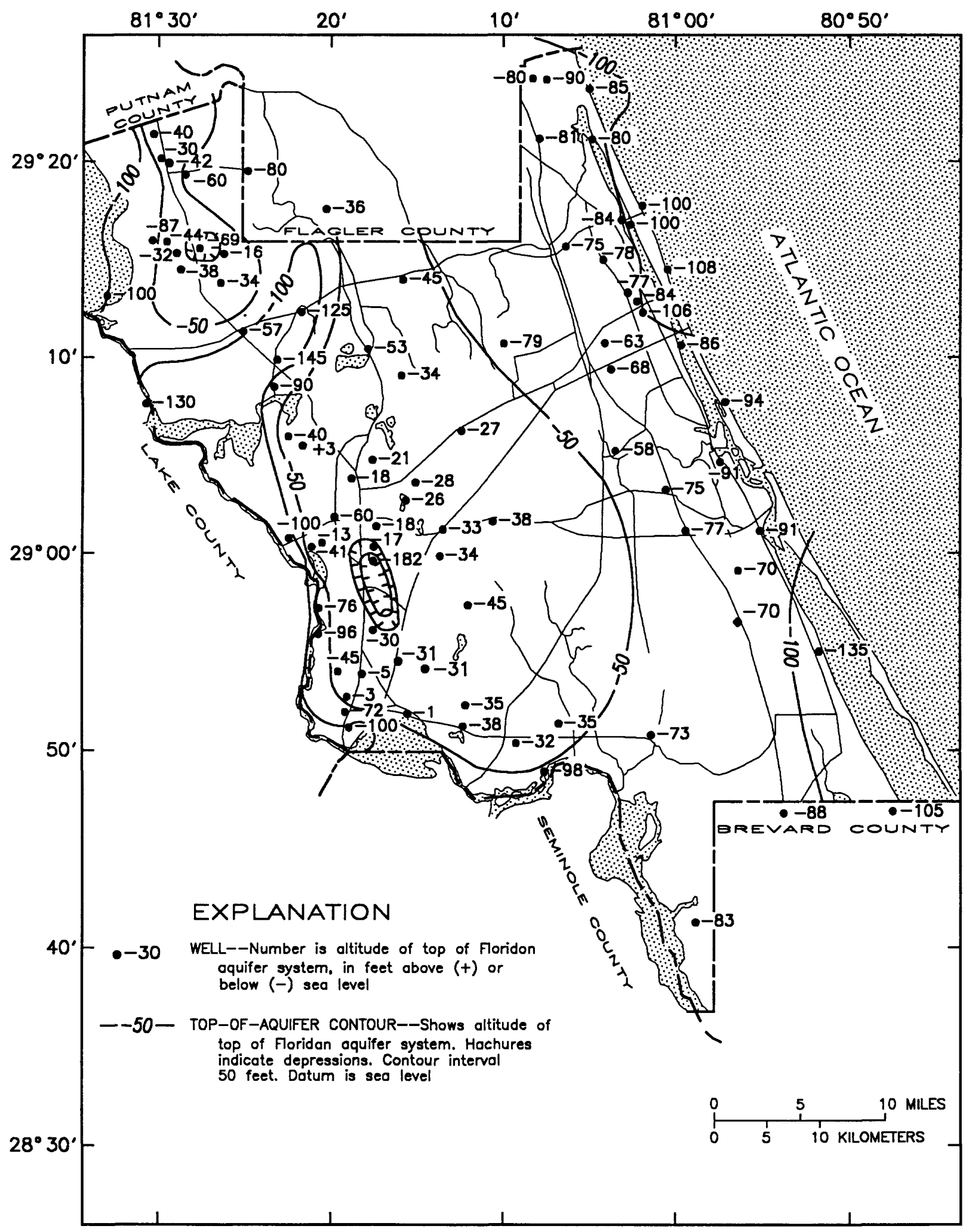

Figure 4. Altitude of top of Floridan aquifer system (from Rutledge, 1985a, fig. 6). 


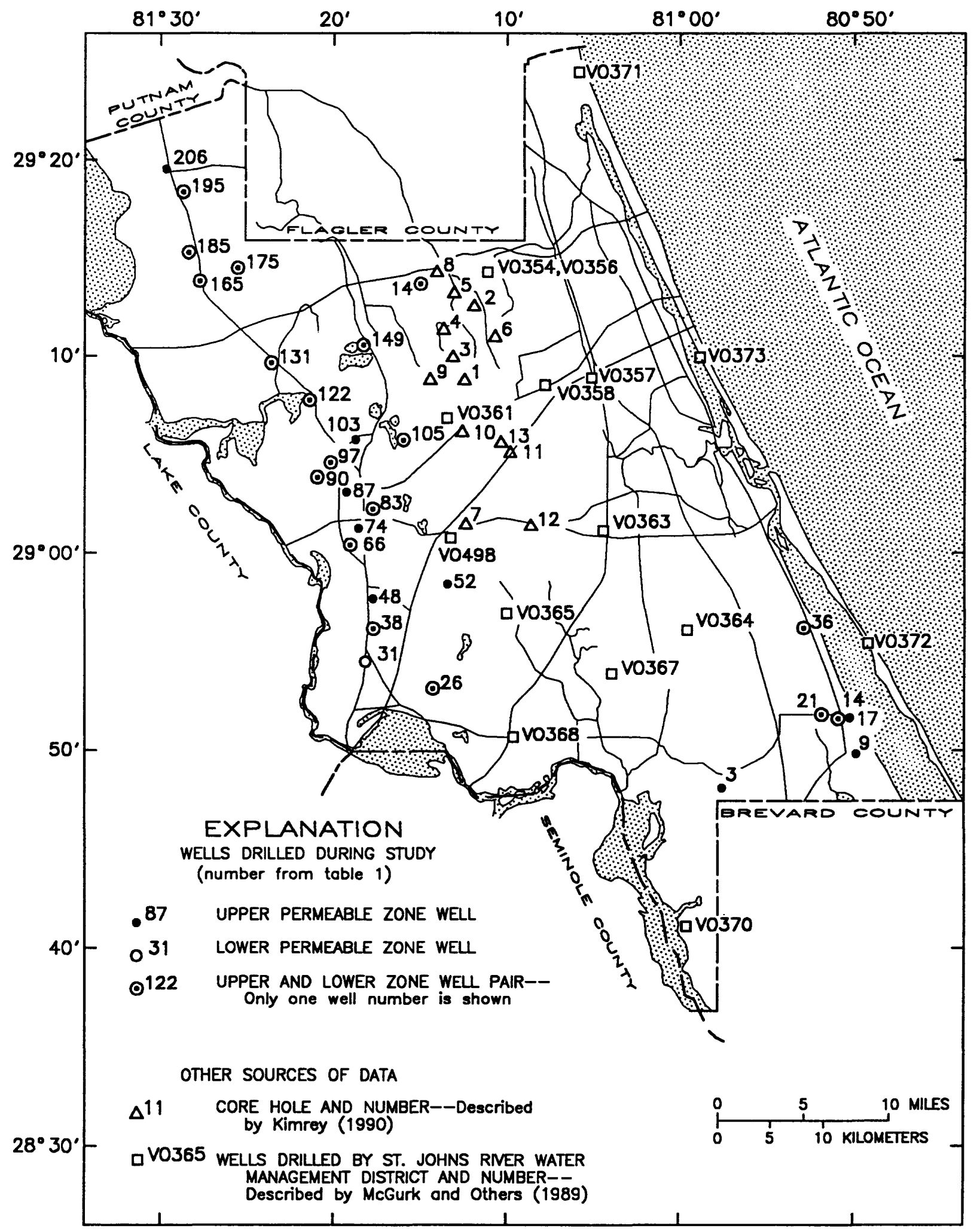

Figure 5. Locations of test wells drilled, core holes, and St. Johns River Water Management District wells. 


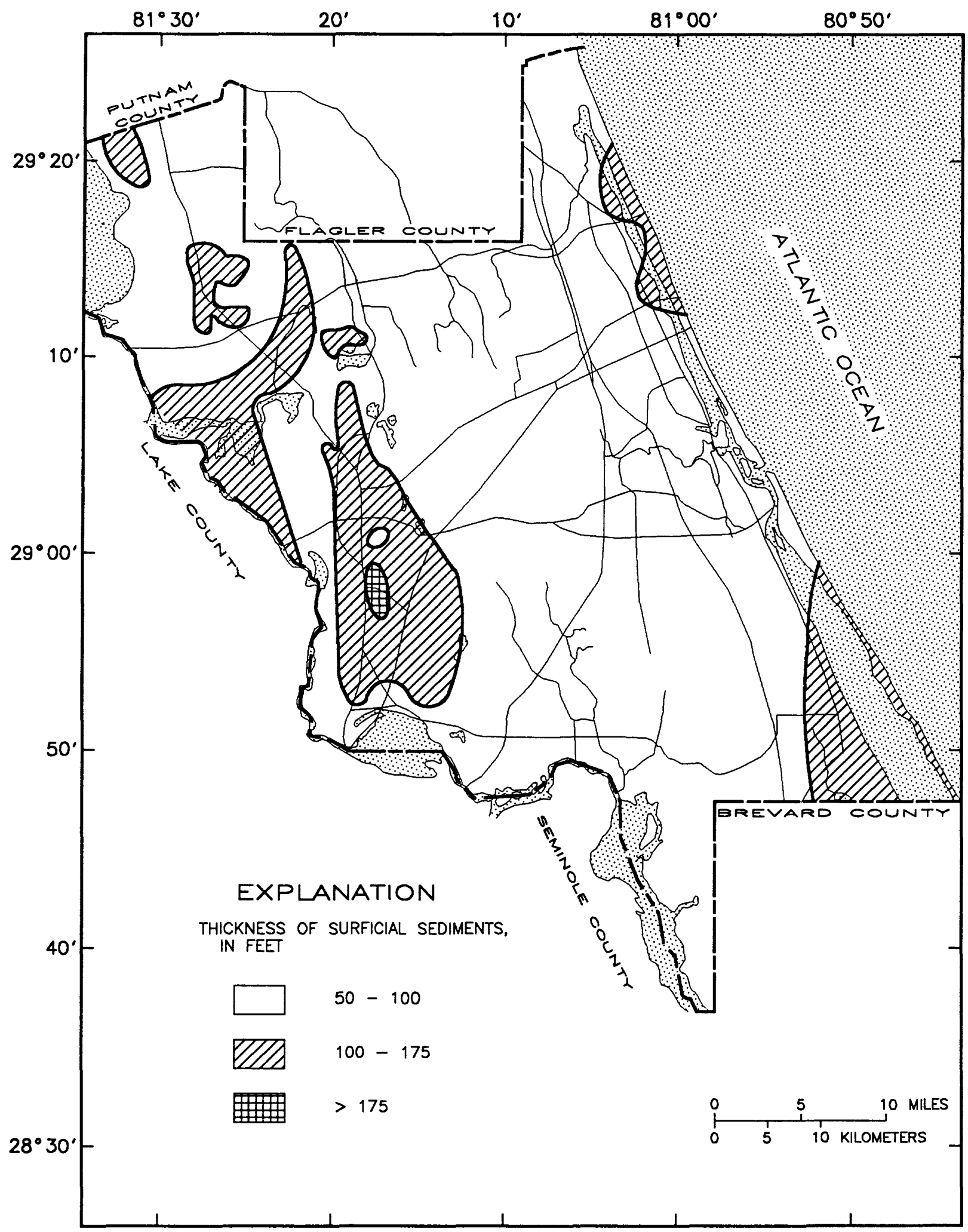

Figure 6. Thickness of sedimerits overlying the Floridan aquifer system. 
another layer of sand and shell about 20 feet thick, which is designated as the lower permeable zone of the surficial aquifer system. In the eastern part of the county, the lower permeable zone is composed mostly of indurated shell (coquina). This lower zone in turn is underlain by more clay and silt; this last sequence forms the confining layer between the surficial aquifer system and the underlying Floridan aquifer system. Knochenmus and Beard (1971, p. 9) concluded that, because the clastic deposits are lenticular and discontinuous, variations in permeability are great.

Geologic sections (locations shown in fig. 7) based on well data from the files of the U.S. Geological Survey, the Florida Geological Survey, and the St Johns River Water Management District are shown in figures 8a-c. Well information is given in table 2. Some wells used in construction of the sections are not in the U.S. Geological Survey data base, so other identification numbers, if applicable, are shown in table 2. Also, many of the wells used to compile the geologic section tap the Floridan aquifer system and, therefore, are not included in the well inventory in table 1.

Many of the logs did not contain sufficient detail to differentiate geologic units of the surficial aquifer system, so although the Hawthorn Formation appears to be absent on some of the sections, its absence or presence cannot be confirmed with the data available. It is a common belief that the absence of the Hawthorn Formation implies that the Floridan aquifer system is unconfined, but generally, in Volusia County, this is true only in isolated places along the De Land Ridge in the vicinity of sinkholes. In many areas, late Miocene or Pliocene-age sediments contain sufficient clay, fine sand, or silt to poorly confine the Floridan aquifer system. Differentiation among geologic formations in the Floridan aquifer system is not within the scope of this investigation.

Section $A-A^{\prime}$ in figure $8 \mathrm{a}$ shows the range in altitude of land surface (10 feet to more than 100 feet above sea level) and top of the Eocene-age carbonates corresponding to the Upper Floridan aquifer (about 40 feet above to about 125 feet below sea level) along the karst ridges in the western part of the county. In contrast, section $C^{-} C^{\prime}$ (fig. 8b), which includes wells along the Silver Bluff Terrace and the Atlantic Coastal Ridge in the eastern part of the county, shows much less variation. Land surface ranges from 5 to about 30 feet above sea level, and the top of the Upper Floridan aquifer ranges from about 75 feet to about 125 feet below sea level.

Natural gamma logs were run on the test wells drilled during the study to help differentiate between the upper and lower permeable zones. Logs, completion depths, and screened sections from selected wells are shown in figures 9a-f. At sites where a pair of wells were drilled, the deeper of the two wells was logged. Although some types of clay do not exhibit high gamma activity, high gamma counts generally indicate a clay layer, whereas low activity usually indicates a clean sand or shell. The approximate boundaries of the upper and lower permeable zones of the surficial aquifer system are shown in figures 9a-f. Because the zones are not continuous over the county, no attempt was made to construct sections between the test well sites. In the following discussion the well numbers refer to table 1 .

At most sites, the gamma-activity peak at a depth of about 20 to 40 feet below land surface delineates the bottom of the upper permeable zone of the surficial aquifer system. The bottom of the lower zone probably is indicated by the peaks at depths of 55 to 60 feet in well 22 (fig. 9b), and at 65 to 70 feet in well 37 (fig. 9c), respectively. At some sites in the western part of the county, such as wells 196 (fig. 9f) and 166 (not shown), gamma activity at the bottom of the lower zone does not appear to increase, and water-level data indicate a good hydraulic connection between the lower zone and the Upper Floridan aquifer. At other sites, such as well 39 (fig. 9c) and wells 176 and 186 (not shown), the deeper well of each pair inadvertently penetrated into the Upper Floridan aquifer, as shown by the much lower gamma activity characteristic of limestone at a depth of 55 feet in well 39.

The log of well 98 (fig. 9e) does not show peaks that would indicate good separation of the zones within the surficial aquifer system, but water levels and water-quality data (discussed in later sections) indicate that the two zones are distinct at this site. Apparently, silt or clay layers not showing a high gamma activity are found at the site.

The $\log$ of well 84 (fig. 9d), which is located in De Land, shows a gamma activity peak at a depth of about 50 to 60 feet that may indicate good separation between zones of the surficial aquifer system; however, neither well would yield water when pumped and shortly after the wells were drilled, both wells became dry. Because of the lack of water-level data, no attempt was made to delineate zones of the surficial aquifer system at well 84 . At well 132 (fig. 9f), in an area of low land surface altitude near Deep Creek, the $\log$ indicates some clay from about 5 to $\mathbf{4 0}$ feet below land surface. Although there does not appear to be a significant clay layer separating the upper and lower zones, based on a 1-foot water-level difference, the tentative delineation of the two zones is obvious in figure $9 f$.

Wells at two sites near the western edge of the Talbot Terrace were also logged. Well 106 (fig. 9e) shows gamma activity peaks which indicate good separation between the upper and lower permeable zones. The deeper well does not appear to penetrate the Upper Floridan aquifer, al though the decline in water level during freeze-protection pumping from the Upper Floridan indicates a good hydraulic connection between the lower permeable zone and the Upper Floridan aquifer at that site. Water levels shown in figure 9e were not measured during freeze-protection pumping. The gamma $\log$ of well 27 (fig. 9b) does not indicate a high gamma-activity clay layer at the completion depth of the well, and the water level in the well was at times similar to that in the Upper Floridan, but during most of the study, the well was dry and would not yield a water sample. 


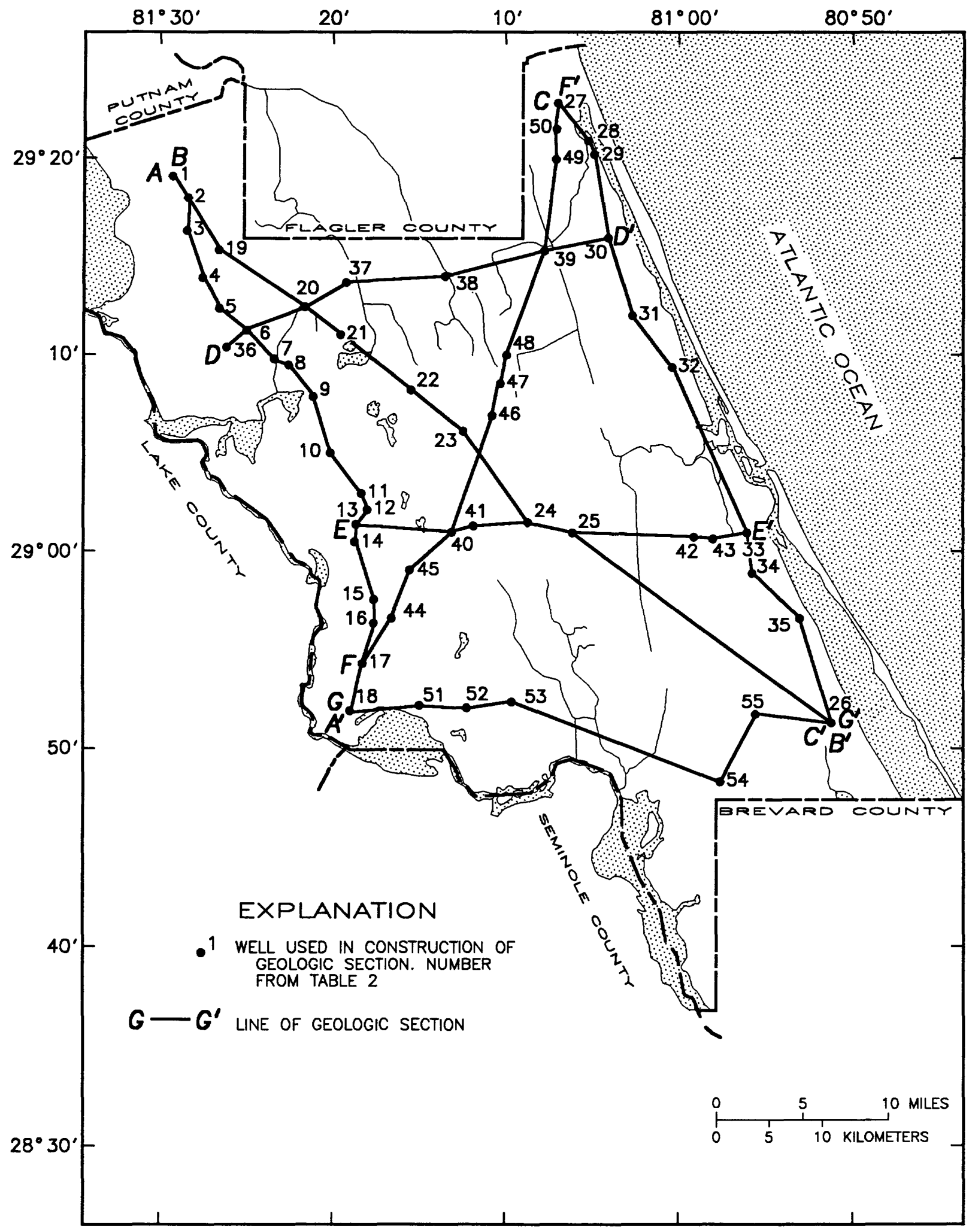

Figure 7. Location of geologic sections. 
Table 2. Wells used for geologic sections

[Agency maintaining well record: SJRWMD, St. Johns River Water Management District; USGS, U.S. Geological Survey; and FGS, Florida Geological Survey; --, indicates no data]

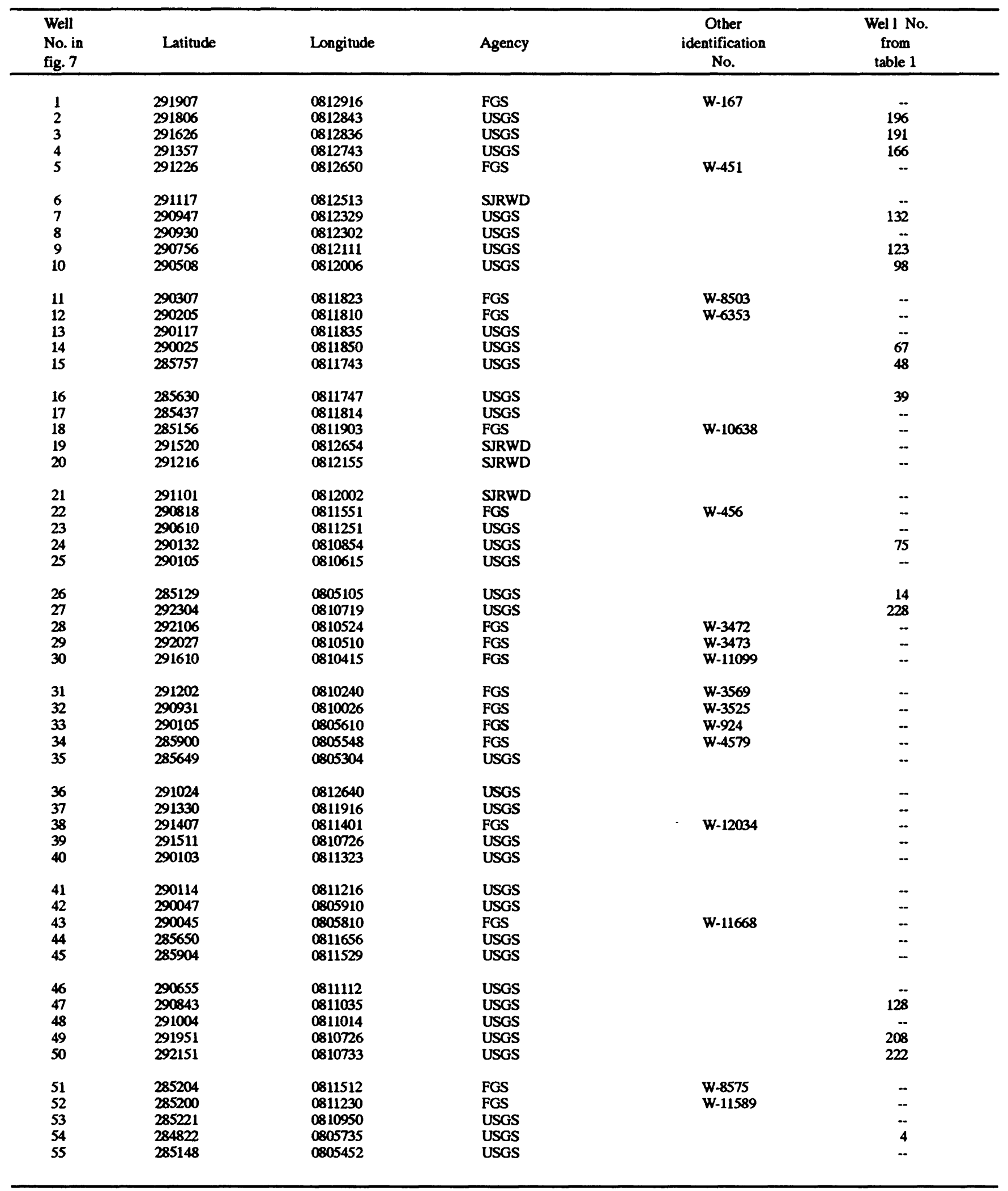



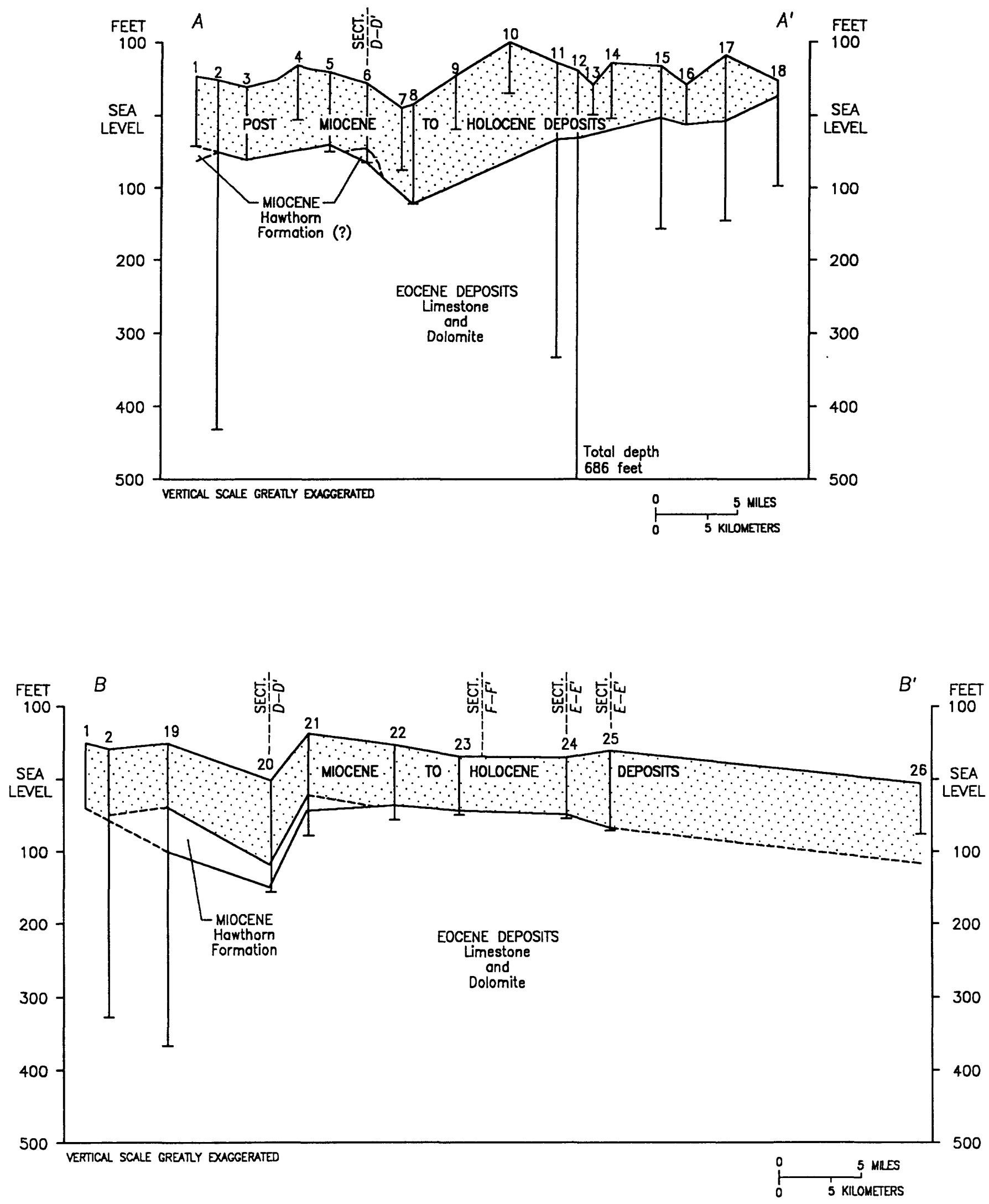

Figure 8a. Geologic sections $A-A^{\prime}$ and $B-B^{\prime}$ (lines of section shown in fig. 7 and plot numbers in table 2). 

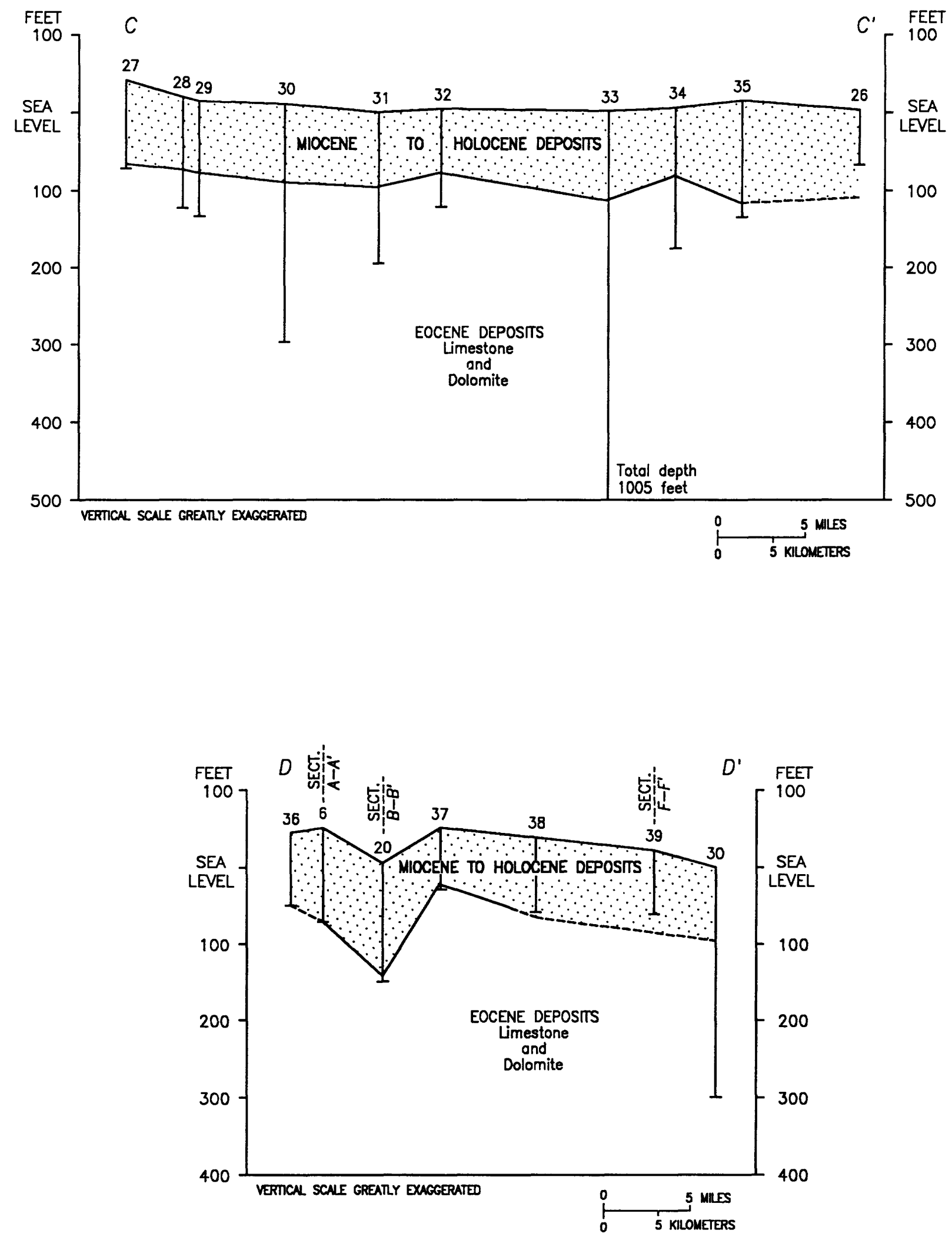

Figure 8b. Geologic sections $C-C^{\prime}$ and $D-D^{\prime}$ (lines of section shown in fig. 7 and plot numbers in table 2). 

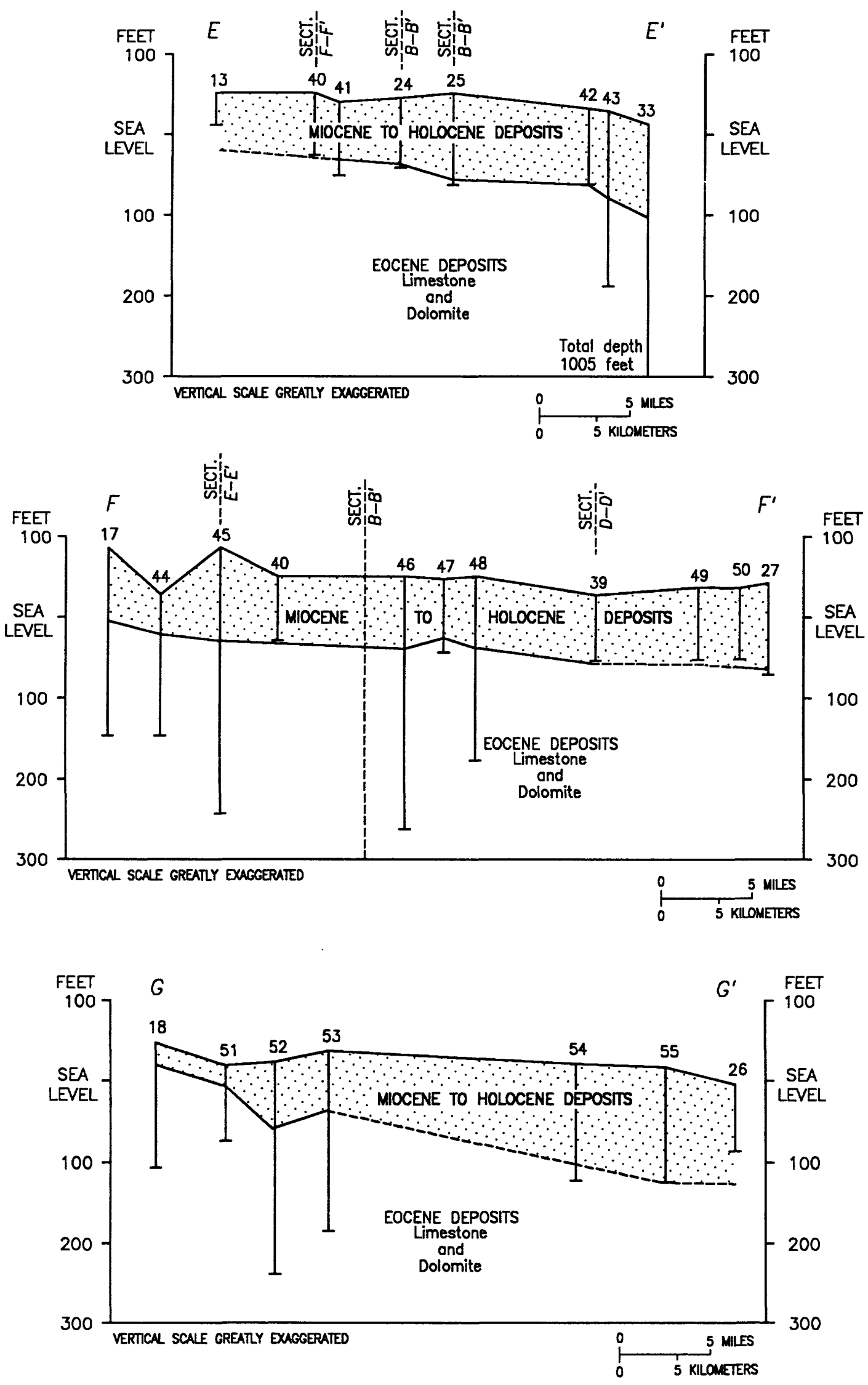

Figure 8c. Geologic sections E-E', F-F', and G-G' (lines of section shown in fig. 7 and plot numbers in table 2). 

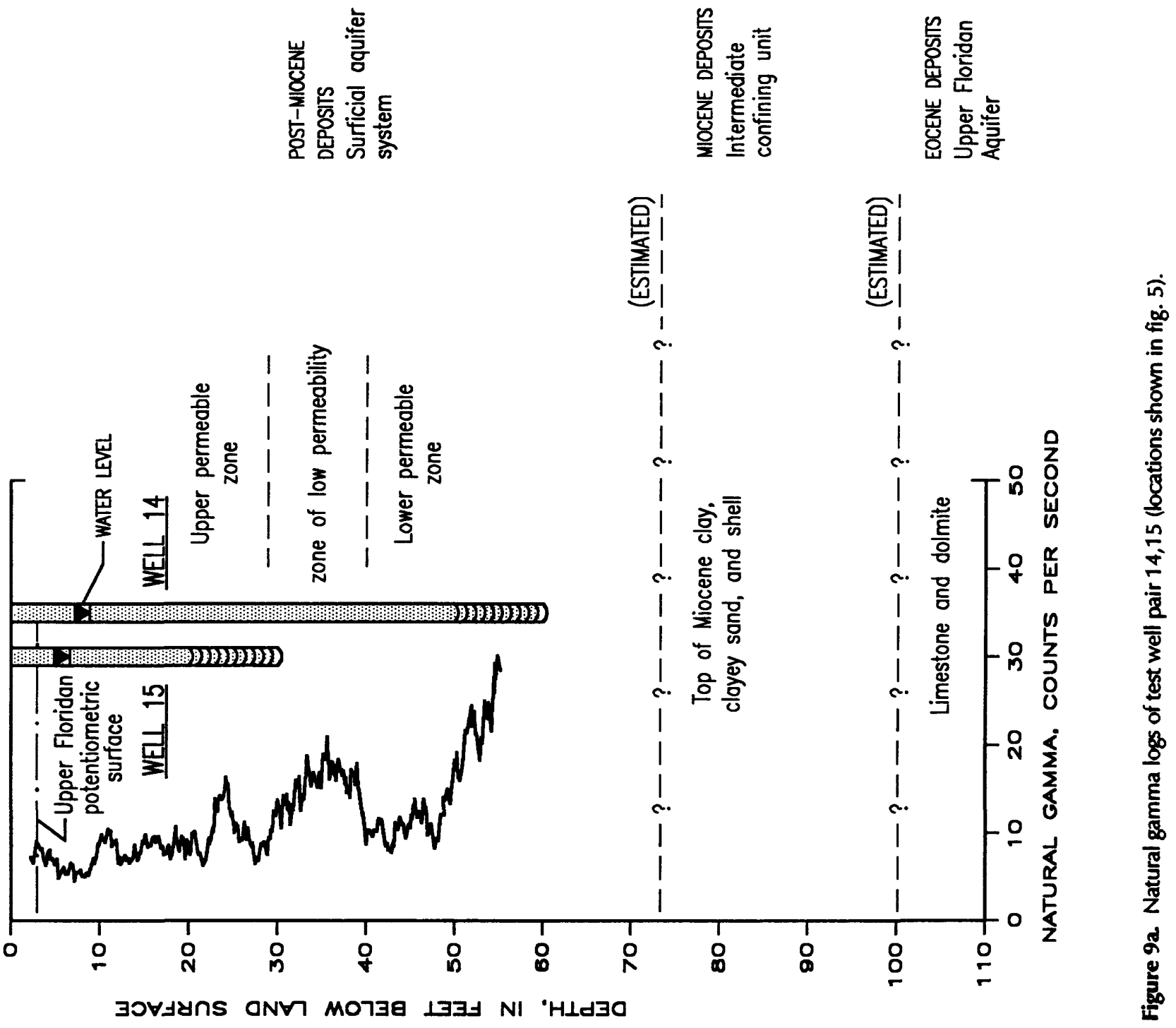


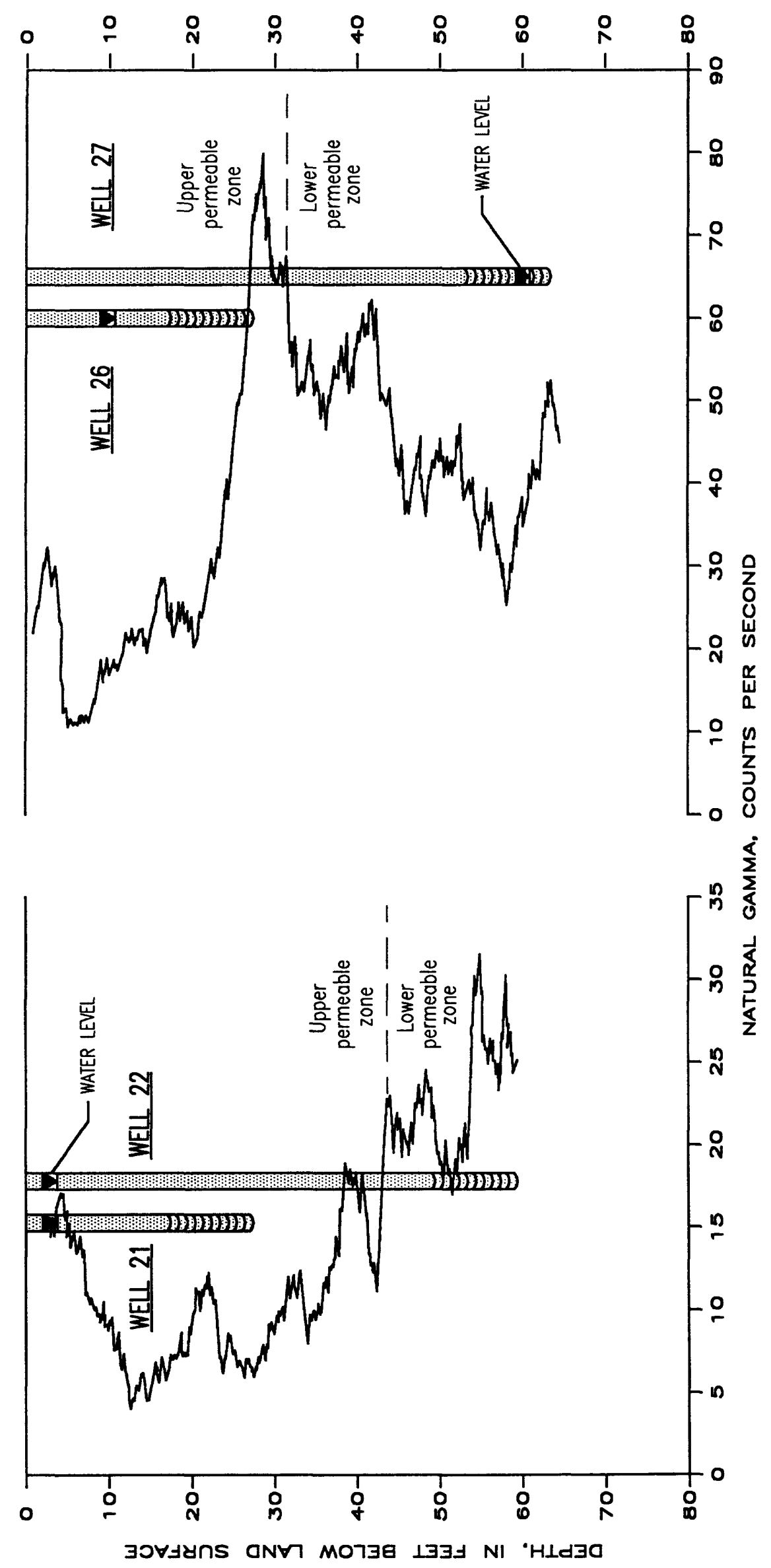

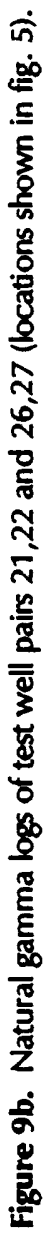




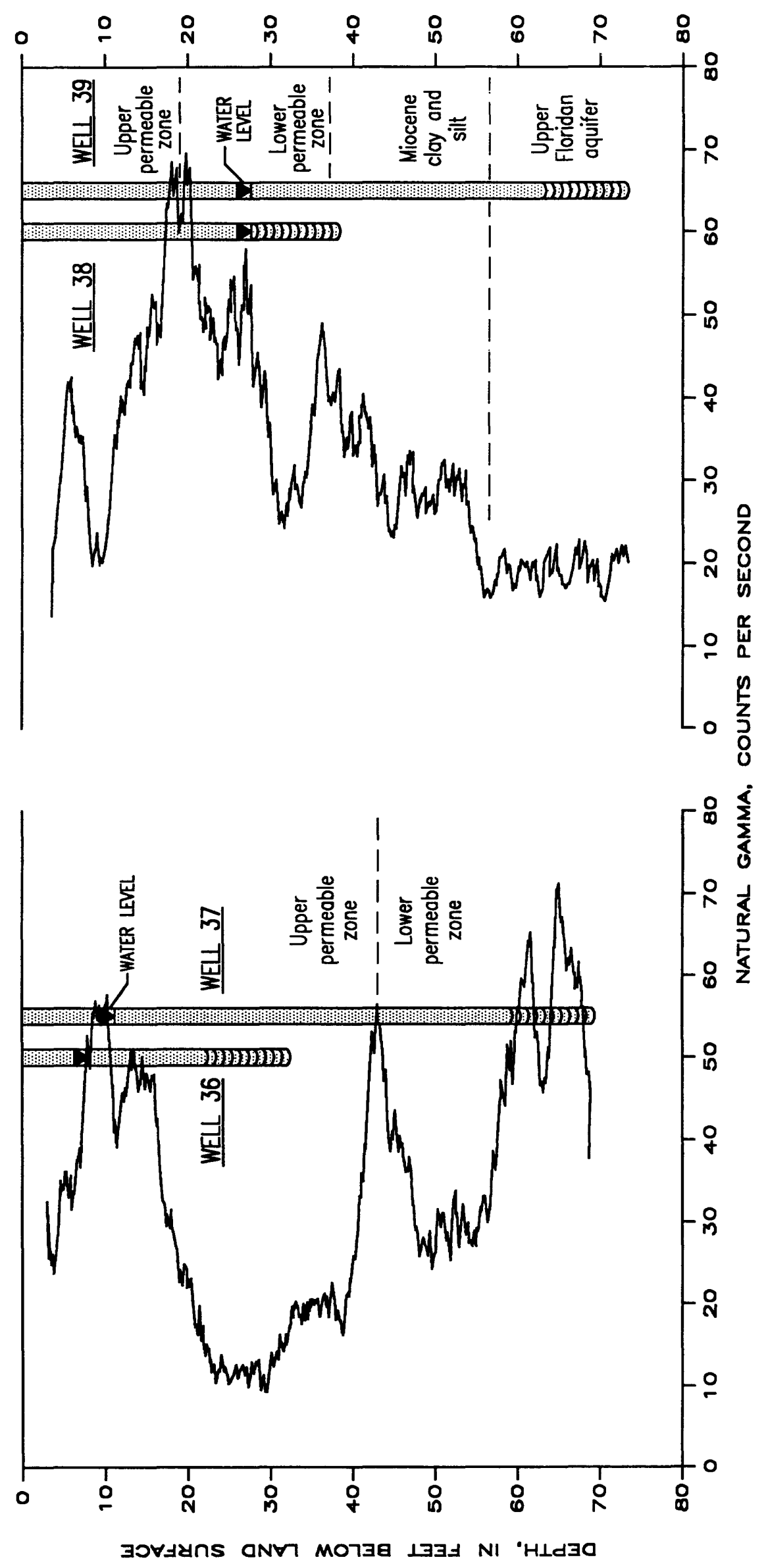

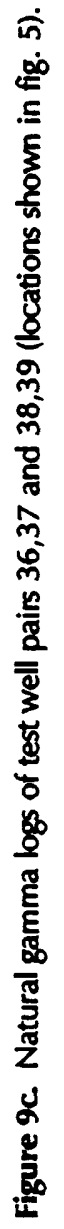




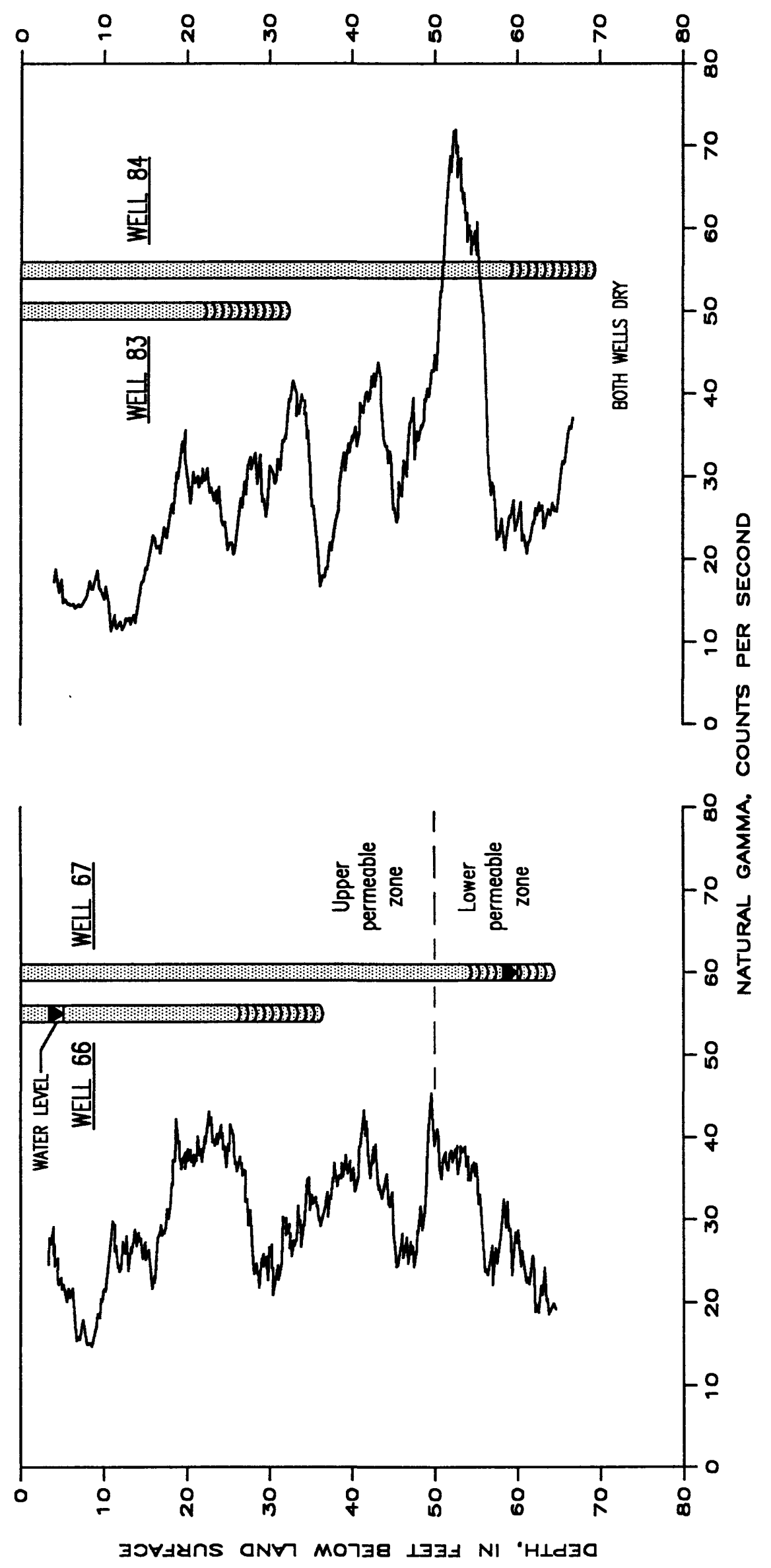

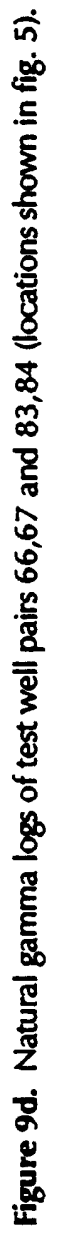



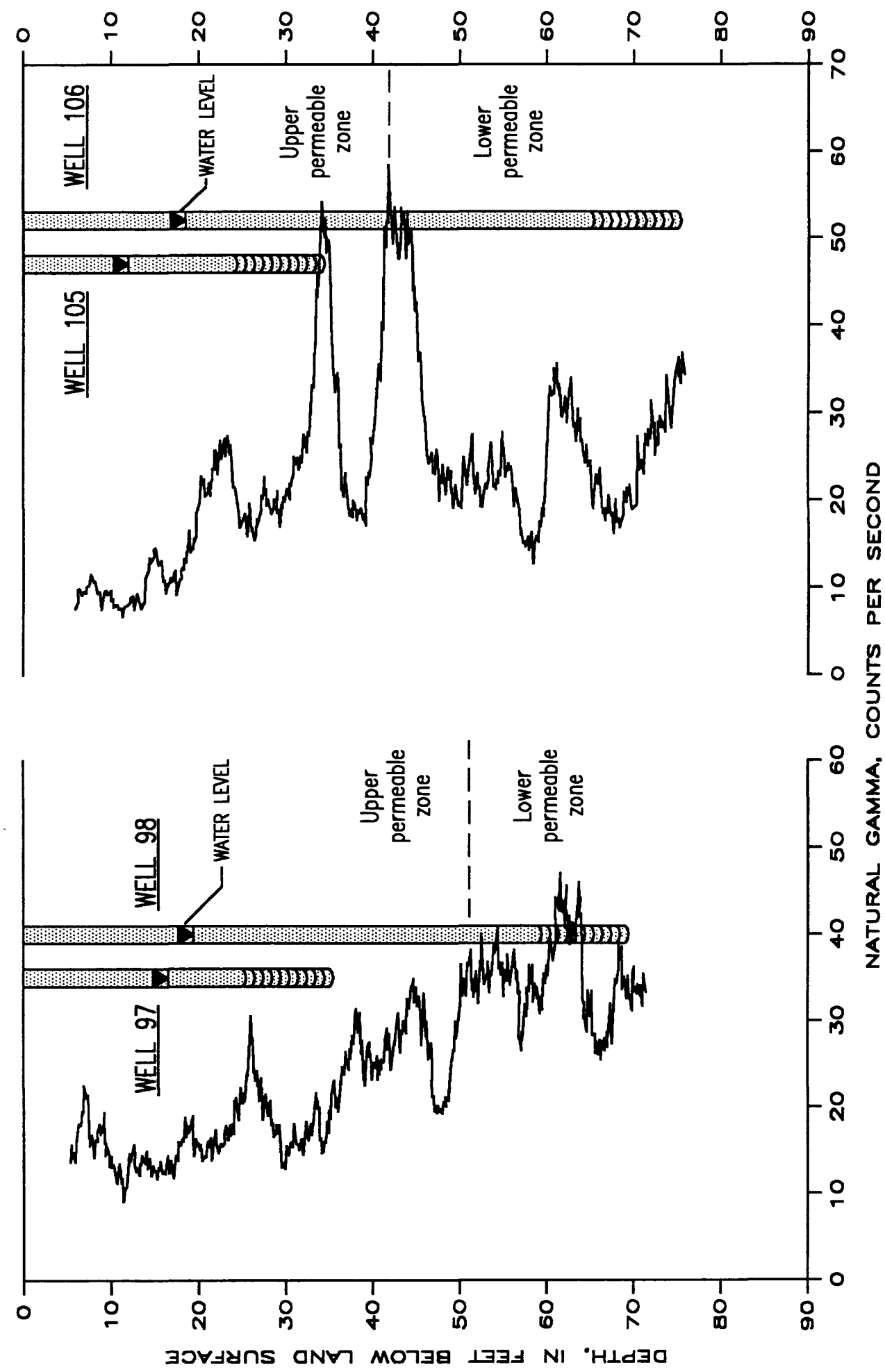


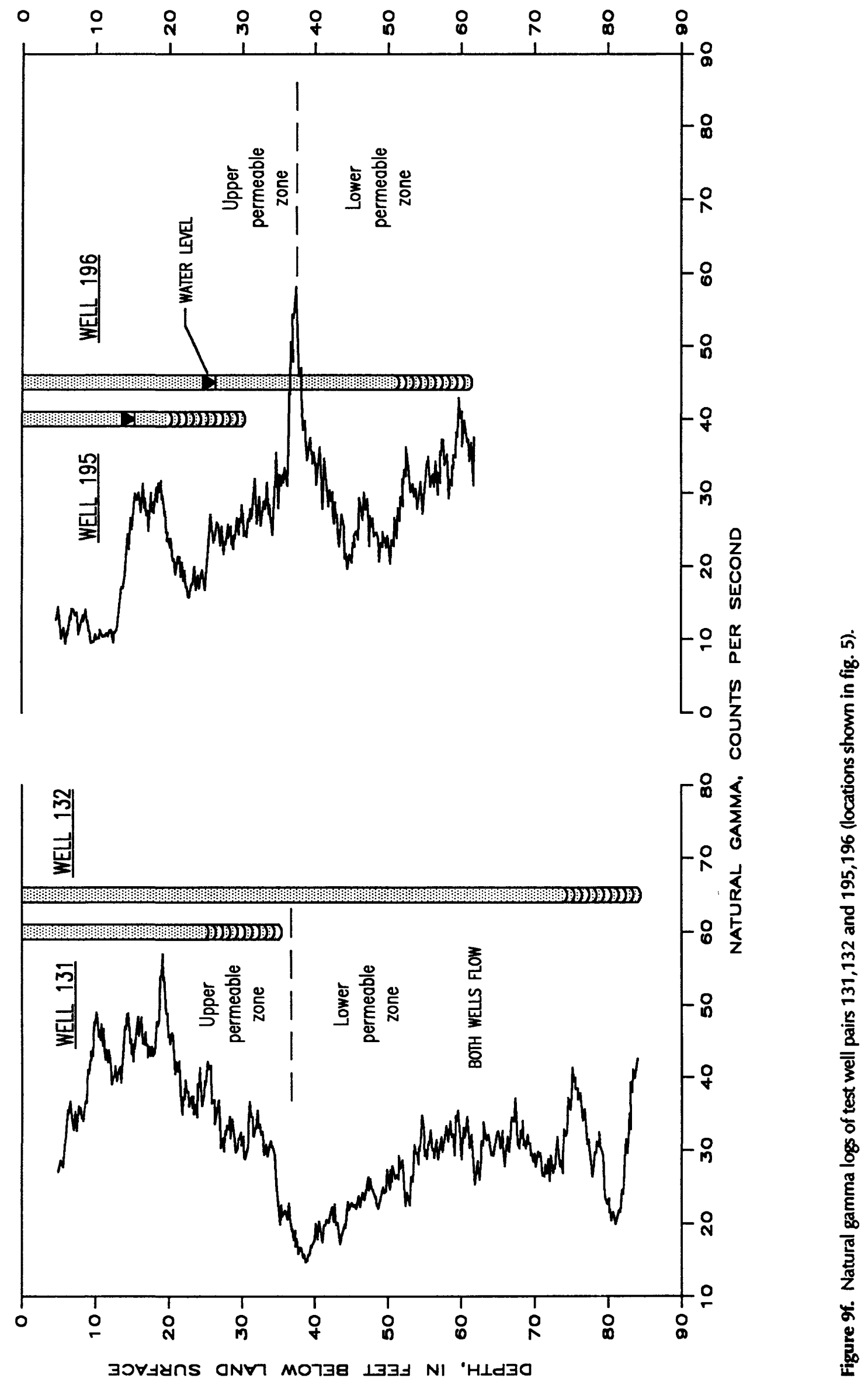


At well 14 (fig. 9a) in the eastern part of the county, the gamma log does not show a peak between the upper and lower permeable zones which could indicate hydraulic connection between the two zones, but when the lower permeable zone was pumped for 19 hours, no response was seen in the upper permeable zone.

From the preceding discussion, it can be seen that, although natural gamma logs can be a useful tool, the results must be interpreted in conjunction with other hydrologic data, such as water levels and water-quality information. Though a peak of high gamma counts usually indicates the presence of a clay layer which can act as a confining layer, the absence of a peak does not necessarily indicate the absence of confinement.

\section{GROUND WATER}

\section{Water Levels}

During the study, water levels were measured periodically in a network of about 90 wells tapping both permeable zones of the surficial aquifer system. Also, water levels are recorded continuously at two U.S. Geological Survey observation wells in the surficial aquifer system in Volusia County. Records of historic water levels collected by Laughlin and Collins (1969), Knochenmus and Beard (1971), and by Gomberg (1985a) were also studied.

\section{Seasonal Fluctuations}

Water levels were measured in wells tapping the upper permeable zone in February through May 1986 (fig. 10) and in September 1986 (fig. 11). Spring water levels usually are lower than fall water levels because only about 30 percent of total yearly rainfall occurs from November through April. In 1986, water levels in wells tapping the upper permeable zone generally were 3 to 6 feet higher in the fall than in the spring, although higher than average rainfall in January and February probably caused spring water levels to be higher than average. Well 195 showed the largest fluctuation in water level during the study, about 5 feet between July 1986 and April 1987 (table 3). Several wells, including wells 105, 131 , and 217 , showed less than 1 foot of water-level fluctuation.

Water levels in wells tapping the lower permeable zone generally fluctuated less than 2 feet, except in wells in the northwestern part on the county affected by pumping from the Upper Floridan aquifer for freeze protection during February 1987. At wells 176 and 196, for example, the fluctuation for the year was about 7 to 11 feet because of the drawdown from freeze-protection pumping. The water levels in the upper permeable zone appeared to be unaffected by the pumping.
The depth below land surface to the water table in the surficial aquifer system varies from one physiographic area to another. On ridge areas, where land-surface altitude is greater than 50 feet above sea level, the water table can be 30 feet or more below land surface, whereas on terraces and in the interridge area near the St. Johns River it is less than 10 feet below land surface. At some sites, either a perched condition exists or the surficial materials are unsaturated. For example, wells 83 and 84 both were dry throughout the study. Well 26 (in the upper permeable zone) showed fluctuations similar to other upper permeable zone wells, but well 27, the lower permeable zone well of the pair, was dry except in September 1986 at the end of the rainy season.

\section{Long-Term Fluctuations}

At present (1989) the U.S. Geological Survey maintains continuous water-level recorders on two wells tapping the upper permeable zone of the surficial aquifer system in Volusia County (wells 143 and 164). Continuous records were collected at three other wells (wells 43,71 , and 111) from 1966 through 1968 . One lower permeable zone well (well 222) has long-term periodic record available. There are no continuous water-level records for wells tapping the lower permeable zone. The locations of long-term observation wells are shown in figure 12.

From May 1985 through May 1987, water-levels fluctuated 3.9 feet in well 143 and 9.8 feet in well 164, both tapping the upper permeable zone. Hydrographs for the two wells and rainfall at De Land for May 1985 through May 1987 are shown in figure 13a. Hydrographs for the period of record (1978 through 1988) for both wells are shown in figure 13b. At well 143, the minimum water level was 32.99 feet above sea level in July 1981 and the maximum was 38.41 feet in September 1984, a difference of 5.42 feet. During the study, water levels in the well fluctuated 3.9 feet. At well 164, the minimum water level was 23.08 feet above sea level in July 1981 and the maximum was 34.16 feet in September 1979, a difference of 11.08 feet. In the summer of 1981, rainfall in central Florida was much less than average.

Water-level measurements at wells 43,71 , and 111 during 1966-68 as reported by Laughlin and Collins (1969) and Knochenmus and Beard (1971) indicated that the water level fluctuated about 18,5 , and 6 feet, respectively.

Data collected by Gomberg (1985a) from well 223 and other nearby wells in northeastern Volusia County during 1981 to 1985 were also examined. At well 223, the water level fluctuated about 8 feet, with the minimum water level in August 1981. At that well, the water level was usually about 10 feet below land surface, but during the summer of 1981 it dropped to about 18 feet below. At a nearby well (not included in table 1) where the water level was usually within 3 feet of land surface, the level dropped to about 12 feet below land surface in 1981, a fluctuation of at least 9 feet for the period of record. 


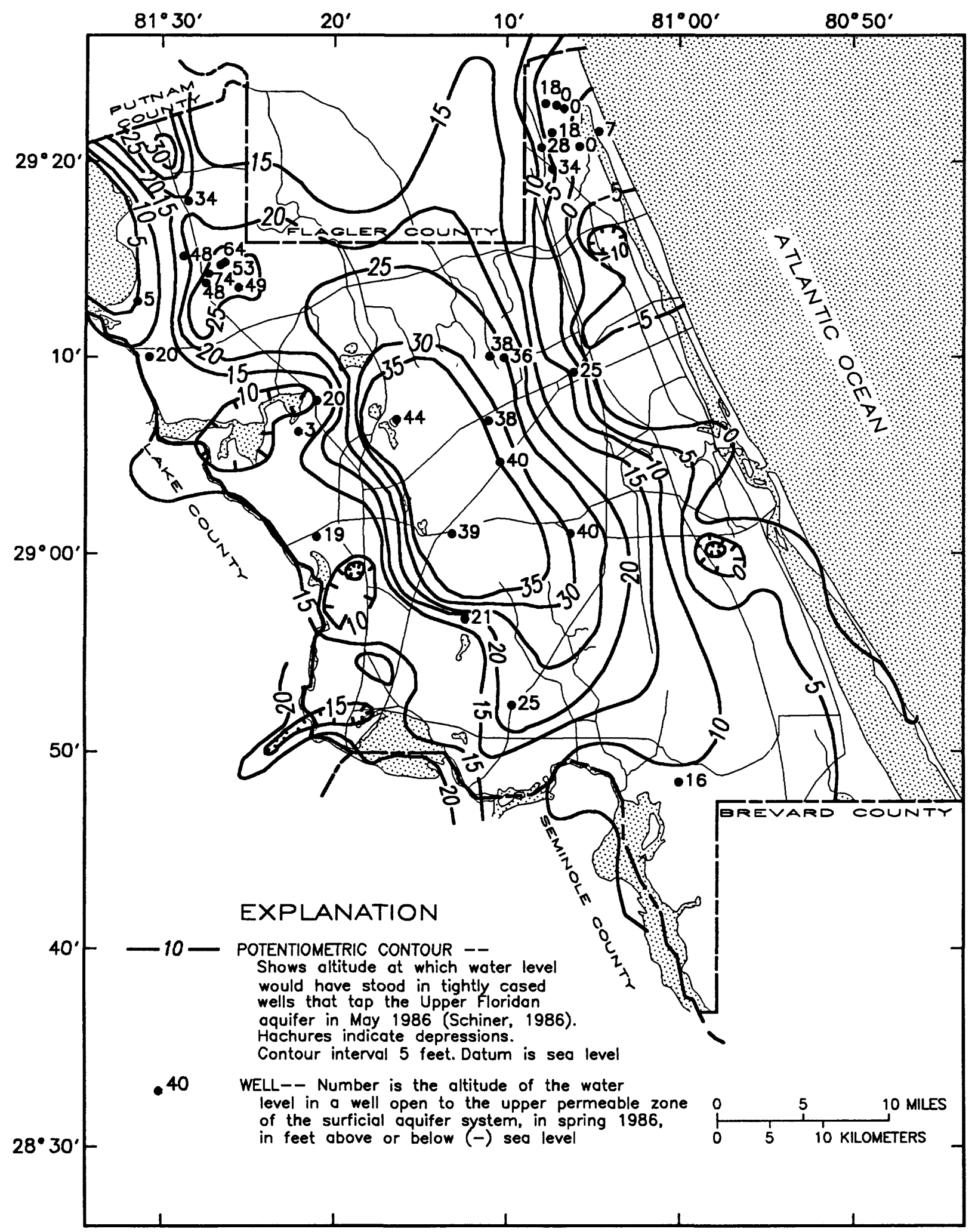

Figure 10. Water levels in wells completed in the upper permeable zone of the surficial aquifer system, February through May 1986, and potentiometric surface of the Upper Floridan aquifer, May 1986. 


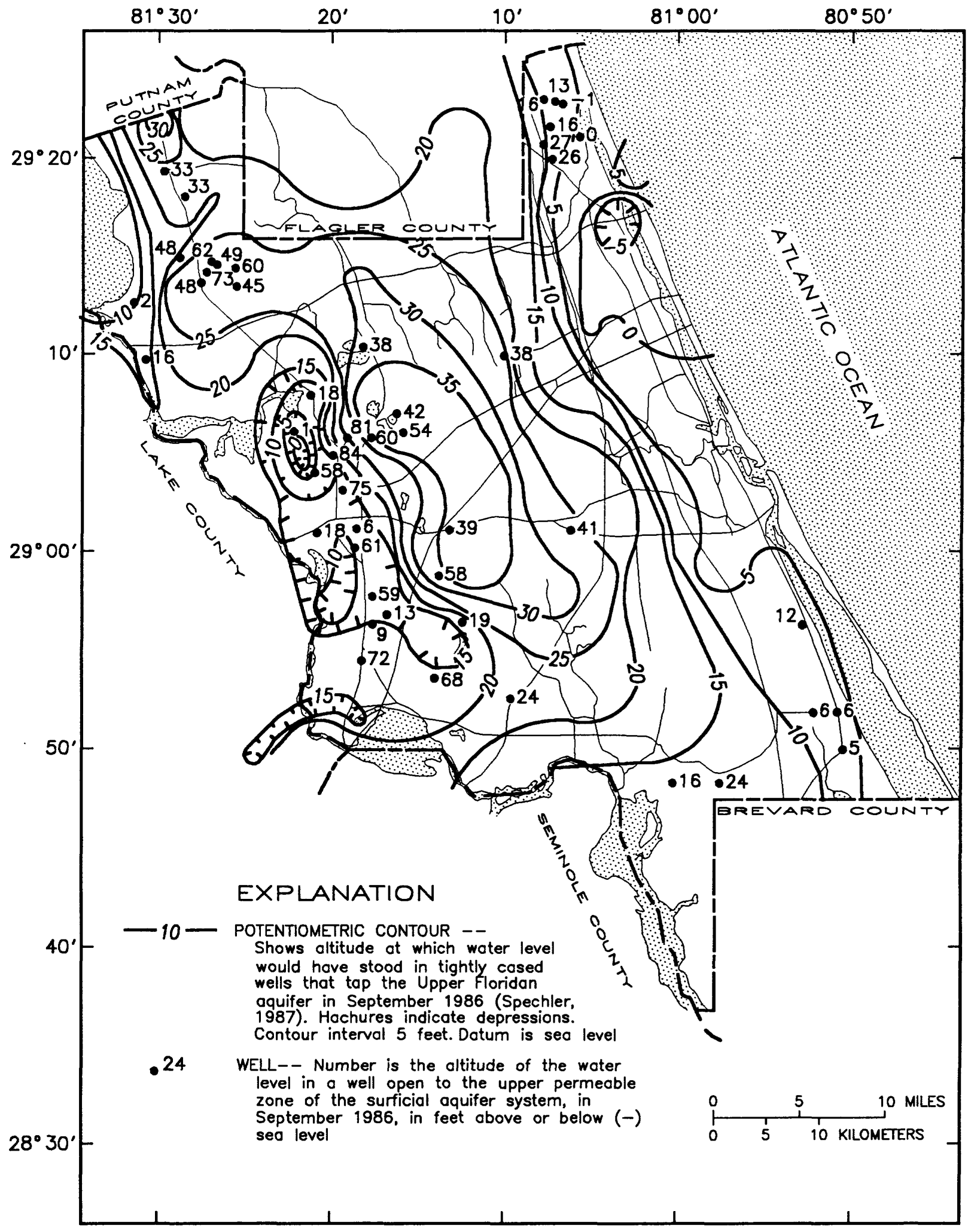

Figure 11. Water levels in wells completed in the upper permeable zone of the srficial aquifer system and potentiometric surface of the Upper Floridan aquifer, September 1986. 
Table 3. Water levels in well pairs drilled during the study

[Well numbers are from table 1. Water level: --, indicates not measured. Aquifer zone: U, upper permeable zone; L, lower permeable zone. Datum is sea level]

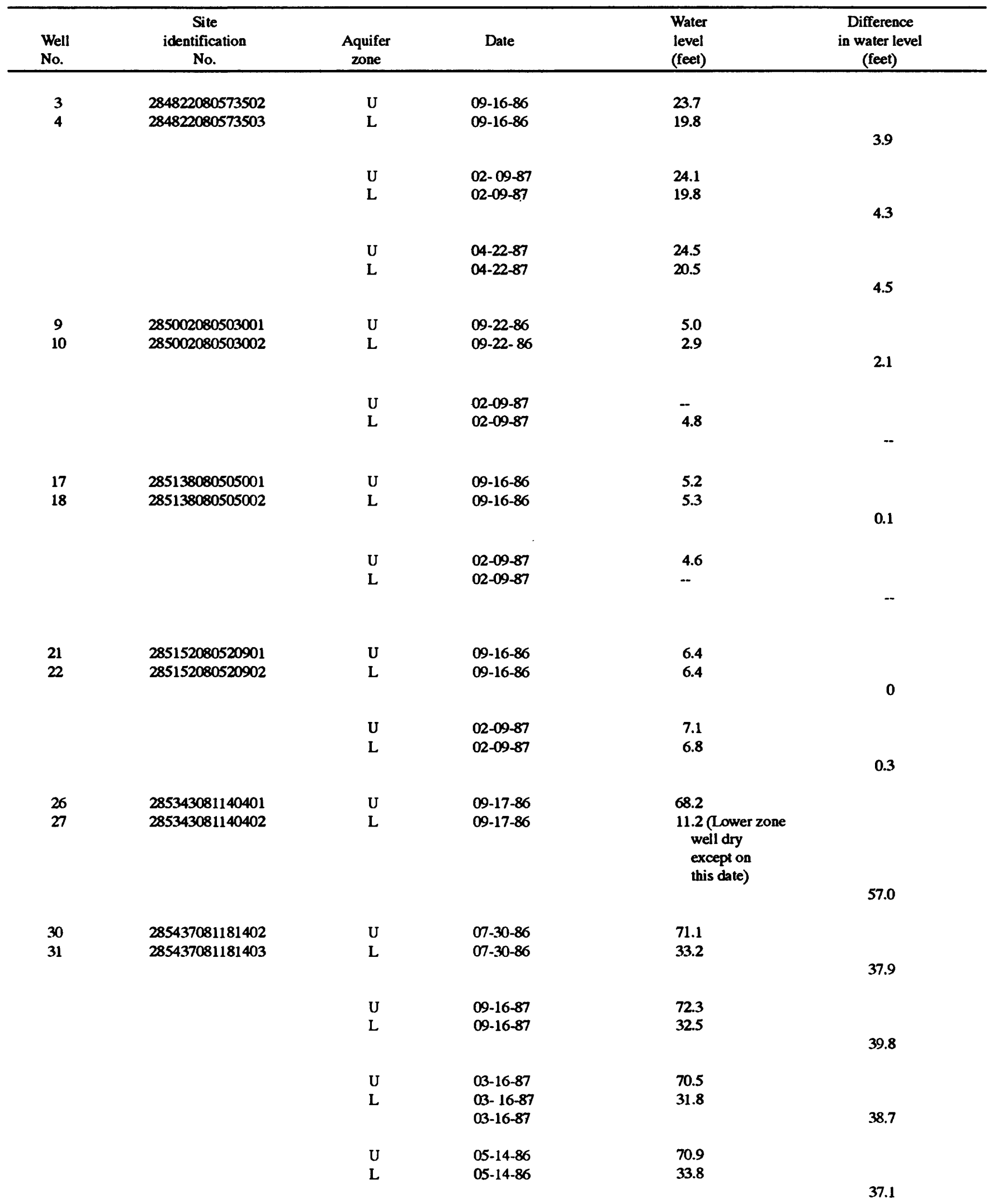


Table 3. Water levels in well pairs drilled during the study-Continued

[Well numbers are from table 1. Water level: --, indicates not measured. Aquifer zone: U, upper permeable zone; L, lower permeable zone. Datum is sea level]

\begin{tabular}{|c|c|c|c|c|c|}
\hline $\begin{array}{l}\text { Well } \\
\text { No. }\end{array}$ & $\begin{array}{c}\text { Site } \\
\text { identification } \\
\text { No. } \\
\end{array}$ & $\begin{array}{c}\text { Aquifer } \\
\text { zone }\end{array}$ & Date & $\begin{array}{l}\text { Water } \\
\text { level } \\
\text { (feet) }\end{array}$ & $\begin{array}{c}\text { Difference } \\
\text { in water leve } \\
\text { (feet) }\end{array}$ \\
\hline \multirow{6}{*}{$\begin{array}{l}36 \\
37\end{array}$} & 285625080525201 & $\mathbf{U}$ & $09-15-86$ & 11.9 & \\
\hline & 285625080525202 & L & $09-15-86$ & 10.2 & 1.7 \\
\hline & & $\mathrm{U}$ & $02-09-87$ & 10.9 & \\
\hline & & & $02-09-87$ & 11.4 & -0.5 \\
\hline & & $\mathbf{U}$ & $04-22-87$ & 123 & \\
\hline & & L & $04-22-87$ & 10.6 & 1.7 \\
\hline \multirow{6}{*}{$\begin{array}{l}38 \\
39\end{array}$} & 285630081174701 & $\mathbf{U}$ & $07-29-86$ & 7.6 & \\
\hline & 285630081174702 & L & $07-29-86$ & 7.7 & -0.1 \\
\hline & & $\mathrm{U}$ & 09-18-86 & 8.5 & \\
\hline & & L & $09-18-86$ & 8.9 & -.4 \\
\hline & & $\mathrm{U}$ & $02-10-87$ & 7.5 & \\
\hline & & L & 02-10-87 & 7.4 & .1 \\
\hline \multirow{8}{*}{$\begin{array}{l}66 \\
67\end{array}$} & 290025081185001 & $\mathbf{U}$ & $07-30-86$ & 58.8 & \\
\hline & 290025081185002 & L & $07-30-86$ & 7.9 & 50.9 \\
\hline & & $\mathrm{U}$ & 09-24-86 & 60.6 & \\
\hline & & L & $09-24-86$ & 7.5 & 53.1 \\
\hline & & $\mathrm{U}$ & $02-10-87$ & 59.2 & \\
\hline & & L & $02-10-87$ & 6.4 & 52.8 \\
\hline & & $\mathbf{U}$ & 03-19-87 & 59.9 & \\
\hline & & $\mathrm{L}$ & $03-19-87$ & 7.4 & 52.5 \\
\hline 90 & 290421081210601 & $\mathrm{U}$ & $09-24-86$ & 57.5 & \\
\hline \multirow[t]{3}{*}{91} & 290421081210602 & L & 09-24-86 & 19.1 & 38.4 \\
\hline & & $\mathrm{U}$ & $02-10-87$ & 57.9 & \\
\hline & & L & $02-10-87$ & 16.5 & 41.4 \\
\hline 97 & 290508081200601 & $\mathrm{U}$ & $09-23-86$ & 83.8 & \\
\hline \multirow[t]{5}{*}{98} & 290508081200602 & $\mathrm{~L}$ & $09-23-86$ & 81.2 & 26 \\
\hline & & $\mathrm{U}$ & $02-10-87$ & 82.6 & \\
\hline & & L & $02-10-87$ & 79.5 & \\
\hline & & $\mathrm{U}$ & $03-18-87$ & 84.1 & \\
\hline & & L & $03-18-87$ & 81.4 & \\
\hline
\end{tabular}


Table 3. Water levels in well pairs drilled during the study-Coritinued

[Well numbers are from table 1. Water level: --, indicates not measured. Aquifer zone: U, upper permeable zone; L, lower permeable zone. Datum is sea level]

\begin{tabular}{|c|c|c|c|c|c|}
\hline $\begin{array}{l}\text { Well } \\
\text { No. }\end{array}$ & $\begin{array}{c}\text { Site } \\
\text { identification } \\
\text { No. } \\
\end{array}$ & $\begin{array}{c}\text { Aquifer } \\
\text { zone }\end{array}$ & Date & $\begin{array}{l}\text { Water } \\
\text { level } \\
\text { (feet) }\end{array}$ & $\begin{array}{c}\text { Difference } \\
\text { in water level } \\
\text { (feet) }\end{array}$ \\
\hline \multirow{8}{*}{$\begin{array}{l}105 \\
106\end{array}$} & 290554081160801 & $\mathbf{U}$ & $07-28-86$ & 54.4 & \\
\hline & 290554081160802 & $\mathbf{L}$ & $07-28-86$ & 47.0 & 7.4 \\
\hline & & $\mathbf{U}$ & $09-23-86$ & 53.8 & \\
\hline & & L & $09-23-86$ & 46.3 & 7.5 \\
\hline & & $\begin{array}{l}\mathrm{U} \\
\mathrm{L}\end{array}$ & $\begin{array}{l}02-10-87 \\
02-10-87\end{array}$ & $\begin{array}{r}54.6 \\
144.6\end{array}$ & \\
\hline & & & & & 10.0 \\
\hline & & $\mathbf{U}$ & $03-24-87$ & 54.4 & \\
\hline & & $\mathbf{L}$ & $03-24-87$ & 46.9 & 7.5 \\
\hline \multirow{10}{*}{$\begin{array}{l}122 \\
123\end{array}$} & 290756081211101 & $\mathrm{U}$ & $04-14-86$ & 20.4 & \\
\hline & 290756081211102 & L & $04-14-86$ & -- & \\
\hline & & $\mathbf{U}$ & $07-17-86$ & 18.9 & \\
\hline & & $L$ & $07-17-86$ & 10.0 & \\
\hline & & $\mathbf{U}$ & $09-23-86$ & 18.2 & \\
\hline & & L & $09-23-86$ & 9.8 & \\
\hline & & & & & 8.4 \\
\hline & & $\mathbf{U}$ & $03-23-87$ & 19.7 & \\
\hline & & L & $03-23-87$ & 10.2 & \\
\hline & & & & & 9.5 \\
\hline 149 & 291032081181301 & U & $07-28-86$ & 38.8 & \\
\hline \multirow[t]{10}{*}{150} & 291032081181302 & L & $07-28-86$ & 31.1 & \\
\hline & & & & & 7.7 \\
\hline & & $\mathbf{U}$ & $09-23-86$ & 38.1 & \\
\hline & & L & $09-23-86$ & 31.2 & \\
\hline & & & & & 6.9 \\
\hline & & $\mathbf{U}$ & $02-10-87$ & 39.1 & \\
\hline & & $\mathrm{L}$ & $02-10-87$ & 30.6 & \\
\hline & & & & & 8.5 \\
\hline & & $\mathbf{U}$ & $04-07-87$ & 41.6 & \\
\hline & & L & 04-07-87 & 32.5 & 9.1 \\
\hline & 291357081274301 & $\mathbf{U}$ & $04-08-86$ & 48.2 & \\
\hline \multirow[t]{3}{*}{166} & 291357081274302 & $\mathbf{L}$ & $04-08-86$ & 27.4 & 208 \\
\hline & & $\mathbf{U}$ & $07-22-86$ & 47.2 & \\
\hline & & L & $07-22-86$ & 24.9 & \\
\hline
\end{tabular}


Table 3. Water levels in well pairs drilled during the study-Continued

[Well numbers are from table 1. Water level: --, indicates not measured. Aquifer zone: U, upper permeable zone; L, lower permeable zone. Datum is sea level]

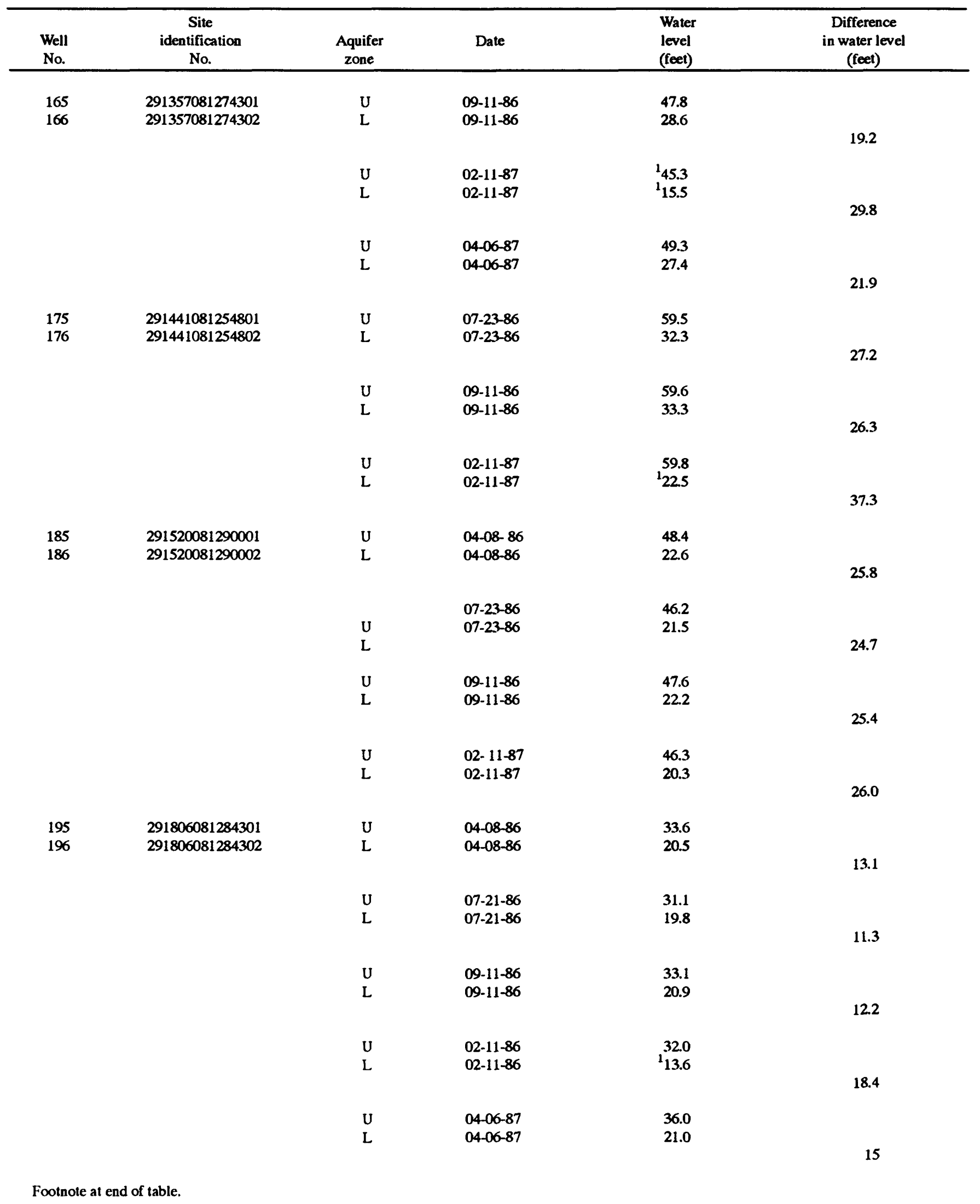


Table 3. Water levels in well pairs drilled during the study-Continued

[Well numbers are from table 1. Water level: --, indicates not measured. Aquifer zone: U, upper permeable zone; L, lower permeable zone. Datum is sea level]

\begin{tabular}{|c|c|c|c|c|c|}
\hline $\begin{array}{l}\text { Well } \\
\text { No. }\end{array}$ & $\begin{array}{c}\text { Site } \\
\text { identification } \\
\text { No. }\end{array}$ & $\begin{array}{l}\text { Aquifer } \\
\text { zone }\end{array}$ & Date & $\begin{array}{l}\text { Water } \\
\text { level } \\
\text { (feet) }\end{array}$ & $\begin{array}{c}\text { Difference } \\
\text { in water level } \\
\text { (feet) }\end{array}$ \\
\hline 214 & 292056081080201 & $\mathbf{U}$ & $03-13-86$ & 28.3 & \\
\hline \multirow[t]{5}{*}{215} & 292056081080202 & $\mathbf{L}$ & $03-13-86$ & 28.2 & 1 \\
\hline & & $\mathbf{U}$ & $09-08-86$ & 27.3 & \\
\hline & & L & $09-08-86$ & 27.1 & .2 \\
\hline & & $\mathbf{U}$ & $04-09-87$ & 28.8 & \\
\hline & & $\mathrm{L}$ & $04-09-87$ & 28.8 & \\
\hline
\end{tabular}

${ }^{1}$ Affected by pumping for freeze protection from the previous night.

Gomberg (1985a) also measured water levels in a well tapping the lower permeable zone. These data show a fluctuation of about 10 feet from 1981 through 1985 . The minimum water level, about 9 feet below land surface, occurred in June 1981.

\section{Comparison of Water Levels}

Comparison of water levels in wells tapping the upper and lower permeable zones of the surficial aquifer system and Upper Floridan aquifer can be useful in indicating the degree of hydraulic connection between aquifers and the direction of the vertical hydraulic gradient. Table 4 shows a comparison of water levels at the test well pairs drilled during this study. In some pairs, for example, such as wells 195 and 196, and wells 185 and 186, the lower permeable zone and Upper Floridan aquifer wells have water levels that are about the same, indicating a good hydraulic connection between the two. At other sites such as wells 30 and 31, and 97 and 98, the water levels are different, and the connection between zones apparently is poor.

Both the magnitude and direction of the vertical hydraulic gradient between the surficial aquifer system and the Upper Floridan aquifer fluctuate seasonally (table 3). At some locations where the gradient is small (such as wells 36 and 37 , and wells 38 and 39), the gradient is sometimes upward, sometimes downward. Under natural conditions (excluding wells affected by freeze-protection pumping) the magnitude of the vertical head difference during the wet season ranged from about 53 feet at wells 66 and 67 to -0.4 foot at wells 38 and 39 . During the dry season, the head difference at wells 66 and 67 was also about 53 feet, whereas at wells 38 and 39 it was 0.5 foot. The magnitude of the difference did not change at any well by more than 3 feet during the study except at some wells in the northwestern part of the county where water levels in the lower permeable zone of the surficial aquifer system were affected by freeze-protection pumping from the Upper Floridan aquifer.

Comparison of water levels also indicates whether a particular area is an area of recharge to, or discharge from, the Upper Floridan aquifer. For example, in wells 105 and 106 the water level in the upper zone well is higher than in the lower zone well, and both are higher than the hydraulic head in the Upper Floridan aquifer; thus the area is a recharge area for the Upper Floridan. In contrast, at wells 9 and 10 and wells 17 and 18, the hydraulic head in the Upper Floridan is higher than in the surficial aquifer system, and thus the area is a discharge area for the Upper Floridan. At those two sites, the hydraulic gradient within the surficial aquifer system is downward, and the lower zone is thus receiving recharge from the upper zone of the surficial aquifer system and from the Upper Floridan aquifer. It is thus probable that ground-water discharges from the lower zone of the surficial aquifer system to Mosquito Lagoon.

\section{Recharge and Discharge}

In Volusia County, recharge to and discharge from the surficial aquifer system are closely related to hydrogeologic conditions in the Upper Floridan aquifer. In many areas of the county, the surficial aquifer system temporarily stores water that later percolates downward slowly to the Upper Floridan. Recharge to the Upper Floridan is important because most of the water withdrawn from wells and discharging naturally from the Upper Floridan in Volusia County comes from recharge occurring within the county. Blue Spring (the ninth largest in Florida with an average 


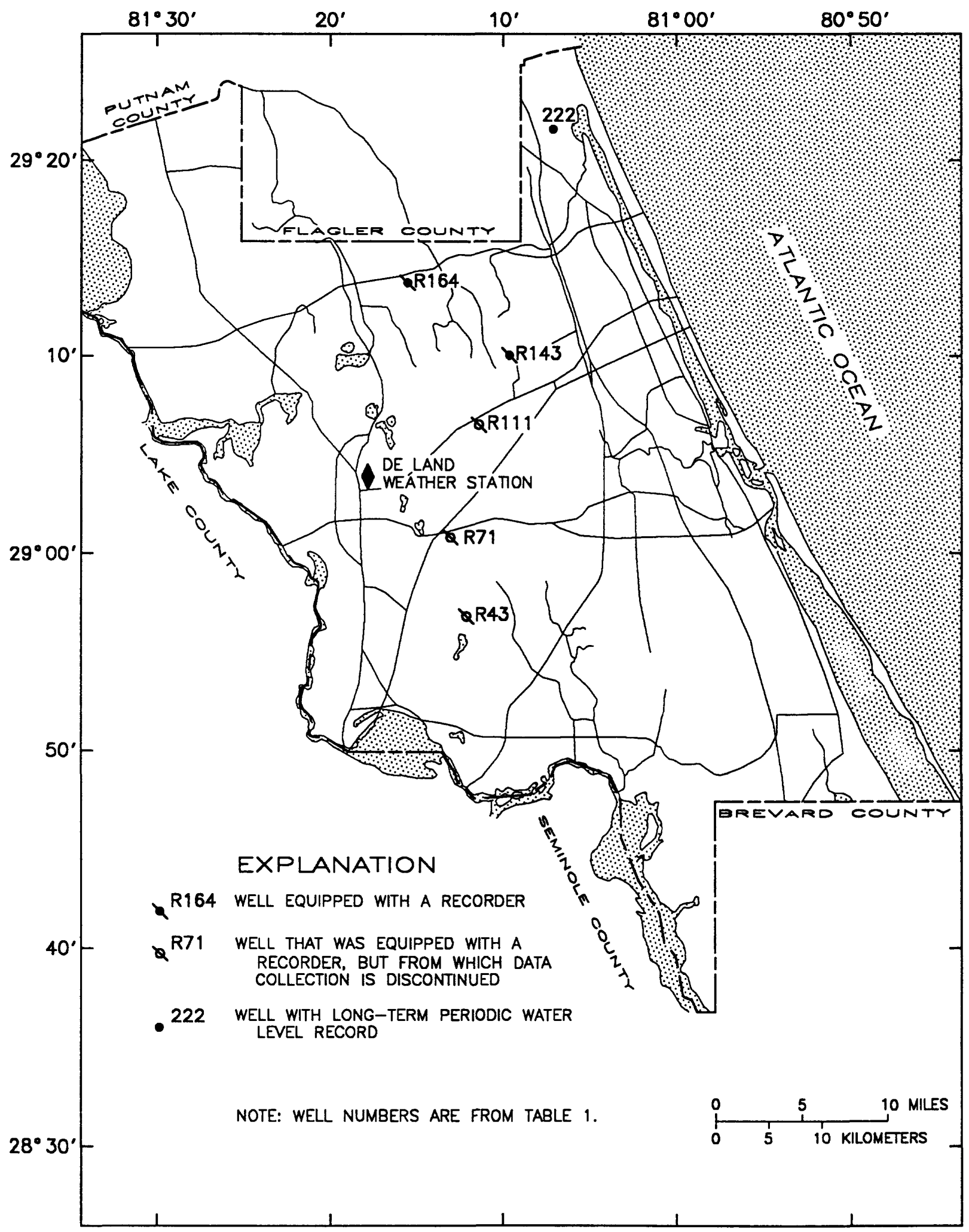

Figure 12. Locations of wells with hydrograph records longer than 2 years. 


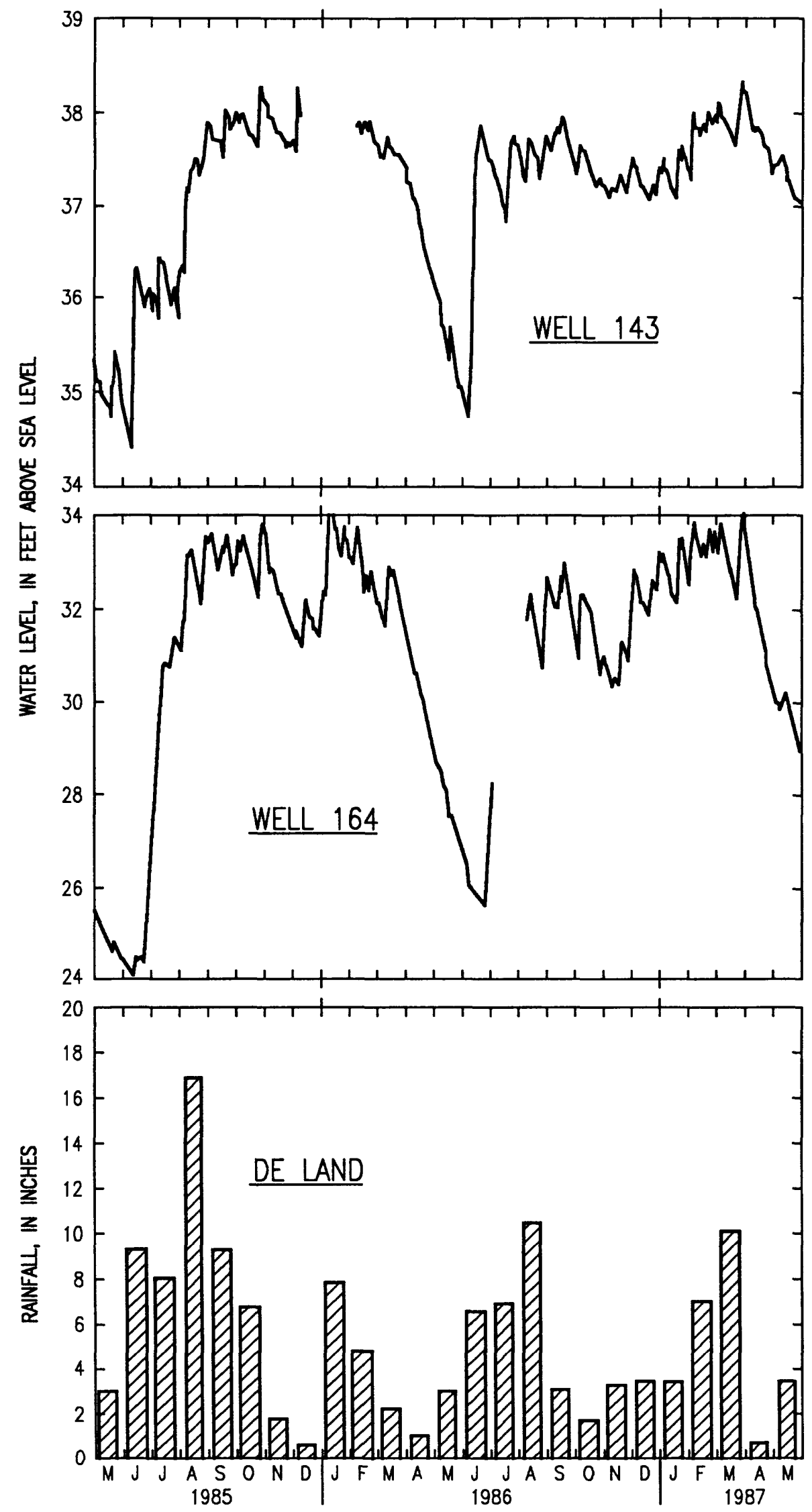

Figure 13a. Hydrographs for wells 143 and 164 completed in the upper permeable zone and rainfall at De Land, May 1985 through May 1987. 

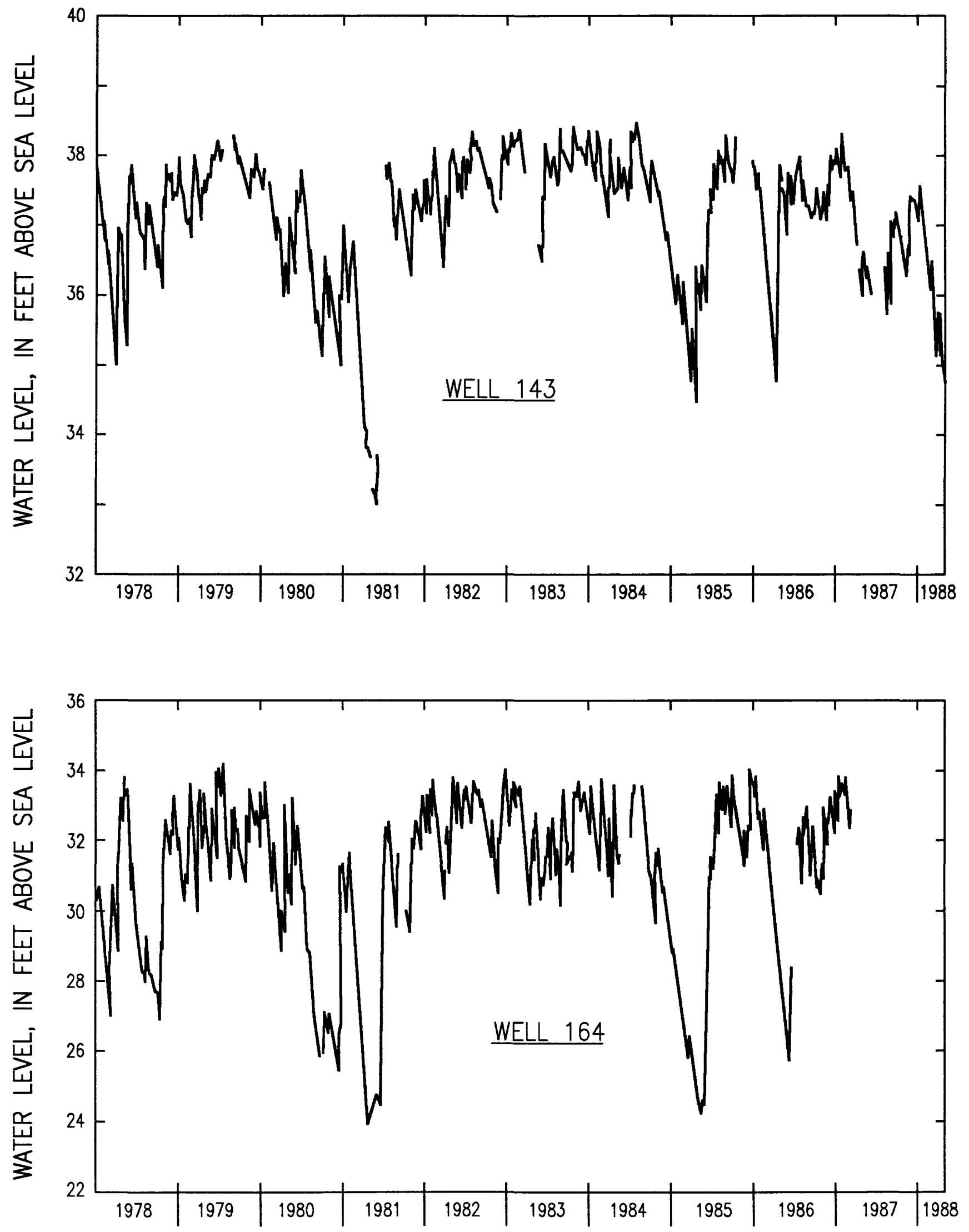

Figure 13b. Hydrographs for wells 143 and 164 completed in the upper permeable zone for the period of record. 
Table 4. Comparison of water levels in wells completed in the surficial aquifer system and the Upper Floridan aquifer, September 1986

[Well numbers are from table 1. U, upper permeable zone; L, lower permeable zone; A, approximate; --, indicates no data]

\begin{tabular}{|c|c|c|c|c|c|c|}
\hline & & & \multirow[b]{2}{*}{$\begin{array}{c}\text { Site } \\
\text { identification } \\
\text { No. } \\
\end{array}$} & \multicolumn{3}{|c|}{ Water level above sea level } \\
\hline \multicolumn{3}{|c|}{$\begin{array}{l}\text { Well No. } \\
\text { and zone }\end{array}$} & & $\begin{array}{l}\text { Upper } \\
\text { zone } \\
\text { (feet) }\end{array}$ & $\begin{array}{c}\text { Lower } \\
\text { zone } \\
\text { (feet) }\end{array}$ & $\begin{array}{c}\text { Upper } \\
\text { Floridan } \\
\text { (feet) }\end{array}$ \\
\hline 3 & & 4 (L) & $284822080573502 / 03$ & 24 & 20 & $18 \mathrm{~A}$ \\
\hline 9 & (U), & $10(\mathrm{~L})$ & $285002080503001 / 02$ & 5 & 3 & $10 \mathrm{~A}$ \\
\hline 17 & (U), & $18(L)$ & $285138080505001 / 02$ & 6 & 5 & $10 \mathrm{~A}$ \\
\hline 21 & (U), & 22 (L) & $285152080520901 / 02$ & 6 & 6 & $10 \mathrm{~A}$ \\
\hline 26 & (U), & 27 (L) & $285343081140401 / 02$ & 68 & 11 & $15 \mathrm{~A}$ \\
\hline 30 & (U), & 31 (L) & $285437081181402 / 03$ & 72 & 32 & 22 \\
\hline 37 & (U), & 37 (L) & $285625080525201 / 02$ & 12 & 10 & 9 \\
\hline 38 & (U), & 39 (L) & $285630081174701 / 02$ & 9 & 9 & $16 \mathrm{~A}$ \\
\hline 66 & (U), & 67 (L) & $290025081185001 / 02$ & 61 & 8 & $8 \mathrm{~A}$ \\
\hline 83 & (U), & 84 (L) & $290243081175301 / 02$ & Dry & Dry & -- \\
\hline & (U), & 91 (L) & $290421081210601 / 02$ & 58 & 19 & $15 \mathrm{~A}$ \\
\hline & & 98 (L) & $290508081200601 / 02$ & 84 & 81 & $15 \mathrm{~A}$ \\
\hline & (U), & $106(\mathrm{~L})$ & $290554081160801 / 02$ & 54 & 46 & $35 \mathrm{~A}$ \\
\hline & (U), & 123 (L) & $290756081211101 / 02$ & 18 & 10 & 12 \\
\hline 149 & (U), & $150(\mathrm{~L})$ & $291032081181301 / 02$ & 38 & 31 & 34 \\
\hline 165 & (U), & $166(\mathrm{~L})$ & $291357081274301 / 02$ & 48 & 29 & $26 \mathrm{~A}$ \\
\hline 175 & (U), & 176 (L) & $291441081254801 / 02$ & 60 & 33 & $30 \mathrm{~A}$ \\
\hline & (U), & $186(L)$ & $291520081290001 / 02$ & 48 & 22 & $22 \mathrm{~A}$ \\
\hline 195 & (U), & $196(\mathrm{~L})$ & $291806081284301 / 02$ & 33 & 21 & $21 \mathrm{~A}$ \\
\hline
\end{tabular}

flow of $105 \mathrm{Mgal} / \mathrm{d}$ ) and Ponce de Leon Springs (average flow $20 \mathrm{Mgal} / \mathrm{d}$ ) are both located in Volusia County. A detailed discussion of water budgets for both the surficial and Upper Floridan aquifer systems in Volusia County is found in Rutledge (1985a, p. 34-38 and p. 45-46).

The main condition that must be met for rainfall to recharge the surficial aquifer system is that the uppermost sediments must be unsaturated and of sufficient permeability to allow downward percolation. This condition occurs in many areas of the county, particularly where the water table in the surficial aquifer system is higher than the potentiometric surface of the underlying Upper Floridan aquifer (a downward vertical hydraulic gradient exists). Such areas are recharge areas for both the surficial aquifer system and the Upper Floridan, and most of the water that recharges the surficial aquifer system in those areas eventually recharges the Upper Floridan. In other areas, where the potentiometric surface of the Upper Floridan is above the water table of the surficial aquifer system (an upward vertical hydraulic gradient exists), the surficial system receives recharge from the Upper Floridan (although the actual rate of recharge may be very low because of the low permeability of intervening sediments). In such areas, rainfall can still recharge the surficial aquifer system as long as the surficial sediments are unsaturated. The surficial aquifer system, thus, can receive recharge from both above and below. Such areas are recharge areas for the surficial aquifer system, but discharge areas for the Upper Floridan aquifer.

\section{Recharge and Discharge Areas}

Recharge and discharge areas generally can be delineated using the physiography and topography of the county (figs. 2 and 3 ) and the relation between the potentiometric surface of the Upper Floridan aquifer and land surface. The relation was mapped by Knochenmus (1968, fig. 3), and is shown in figure 14. It is still (1989) considered valid because no significant change in the potentiometric surface has occurred since the figure was compiled.

Another indicator that can be used to help delineate recharge areas is runoff. Rainfall not used by plants or evaporated must either contribute to surface runoff or recharge the ground-water reservoir. Knochenmus (1968, fig. 2) prepared a map showing annual rainfall and annual runoff for Volusia County which is probably still applicable. Runoff data from that map are shown in figure 15. Streamflow in Volusia County is mostly outflow from the surficial aquifer system because all significant surfacedrainage systems in Volusia County have their headwaters 


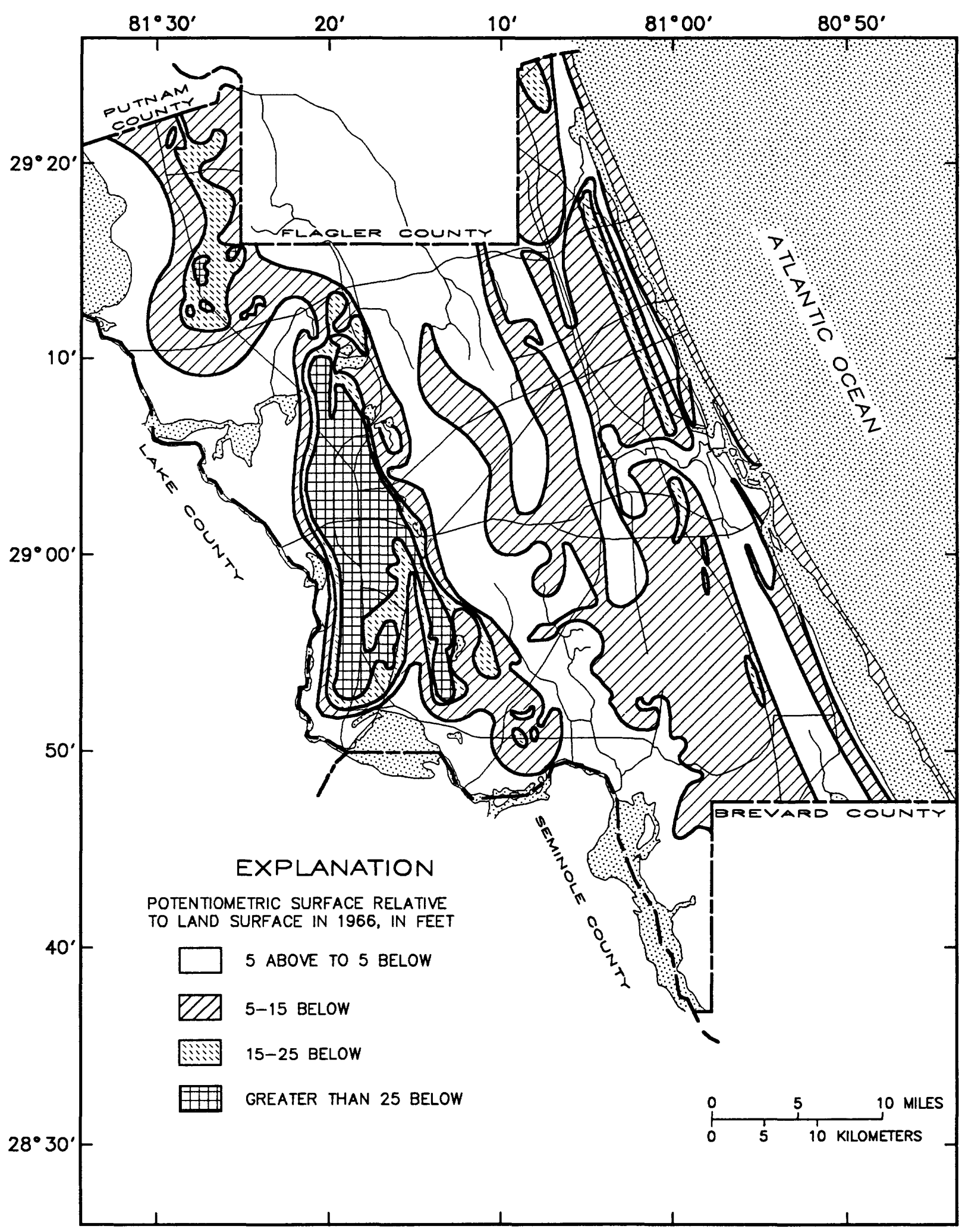

Figure 14. Relation of the potentiometric surface of the Upper Floridan aquifer to land surface (from Knochenmus, 1968, fig. 3). 


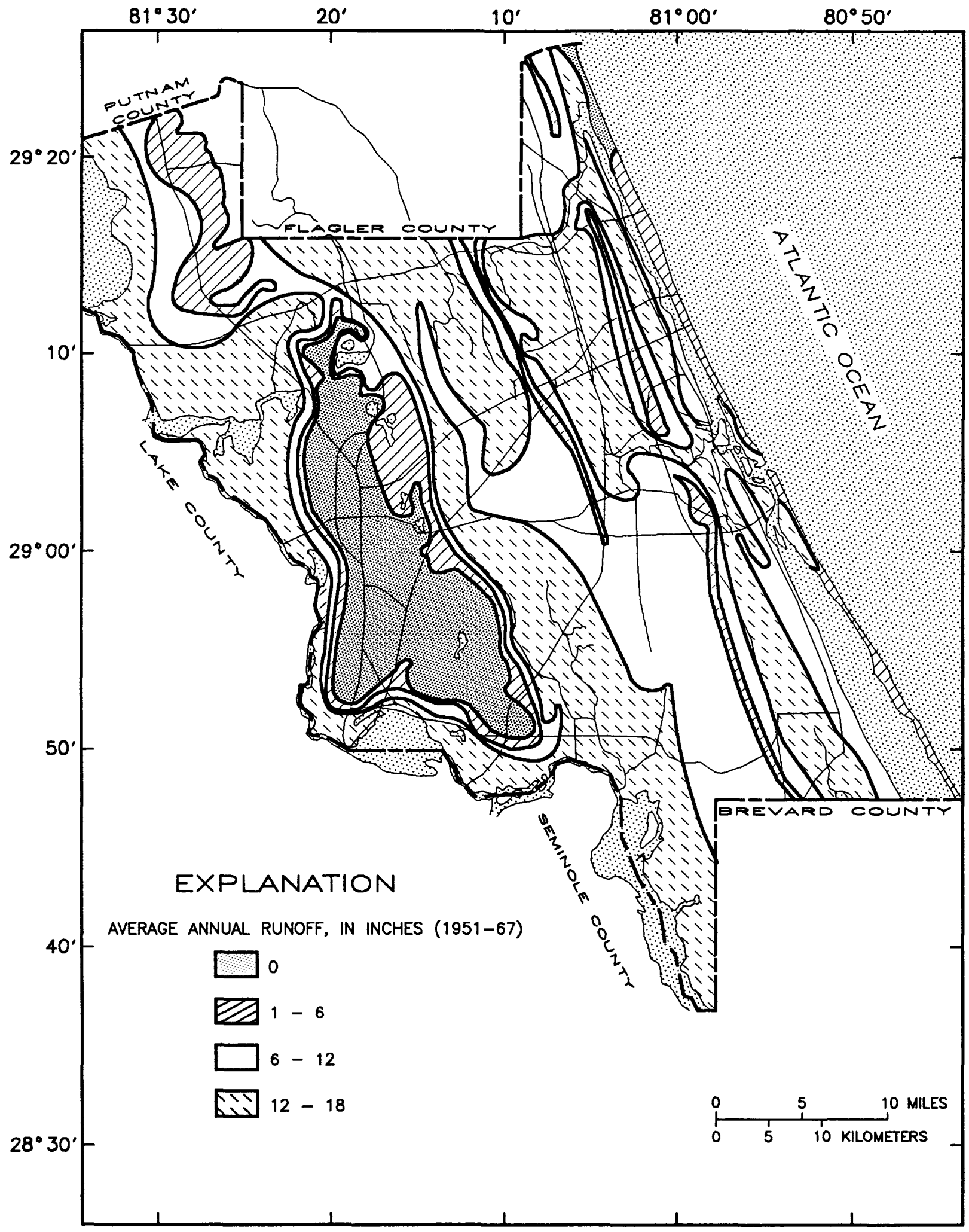

Figure 15. Average runoff (from Knochenmus, 1968, fig. 2). 
within the county (Rutledge, 1985a, p. 36). The following discussion shows how figures 14 and 15 are used to delineate recharge areas in different parts of the county.

In the western part of the county, the De Land and Crescent City Ridges (fig. 2) are recharge areas for both the surficial aquifer system and the Upper Floridan aquifer. Throughout the area, the land surface altitude is mostly greater than 50 feet (fig. 3). The potentiometric surface of the Upper Floridan aquifer is at least 15 feet below land surface throughout most of the area and more than 25 feet below land surface in some of the area (fig. 14). The ridges, which are karst areas, have no surface drainage and thus no runoff (fig. 15). Recharge rates to the surficial system are high, and most of the water that enters the surficial aquifer system moves relatively quickly downward, recharging the Upper Floridan aquifer. By contrast, in the areas of relatively low land surface altitude between the two ridges and along the valley of the St. Johns River, rejected recharge to the surficial aquifer system occurs because the unsaturated surficial sediments are thin and there is a persistent upward vertical hydraulic gradient.

On the relatively flat Talbot and Pamlico Terraces (fig. 2) in the central part of the county, the altitude of land surface is generally about 25 to 50 feet (fig. 3) and the potentiometric surface of the Upper Floridan aquifer ranges from slightly above to about 15 feet below land surface. The area produces about 6 to 18 inches of runoff per year (fig. 15). In most of the area there is a downward vertical hydraulic gradient but it is very small and, because of the flat land surface and low transmissivity in the Upper Floridan aquifer, the surficial sediments remain saturated, or nearly so, much of the time. Kimrey (1990) concluded that recharge is being rejected from the surficial aquifer system along the western edge of the Talbot Terrace. Computer simulations of a test area in central Volusia County, by Bush (1978), indicate that significant amounts of the rejected recharge could be captured by lowering heads in the Upper Floridan. Thus, in the central part of the county, the surficial aquifer receives recharge at a slow rate, acts as a storage bank for water that can slowly percolate downward to the Upper Floridan aquifer, and also discharges excess water. In the relatively flat area of the terrace, land surface relief of only 5 feet can be the difference between a swampy "bay" where recharge is rejected, or a dry "island," where water can infiltrate and percolate downward at a slow rate.

Rima Ridge (fig. 2), which separates the Talbot and Pamlico Terraces, is higher in altitude than the surrounding terraces. It is an important area of local recharge to the surficial aquifer system and to the Upper Floridan as well, but because of its small area, cannot be considered a major recharge area.

In the eastern part of the county, sandy beach ridges with altitudes of about 25 feet alternate with low interridge areas with altitudes of about 5 to 10 feet (figs. 2 and 3). The potentiometric surface of the Upper Floridan aquifer (fig. 14) in some places is above land surface, and generally no more than 15 feet below land surface (except along the northern part of the Atlantic Coastal Ridge (fig. 2) where the potentiometric surface may be as much as 25 feet below land surface). Runoff ranges mostly from 6 to 18 inches per year, although on the Atlantic Beach Ridge (the barrier island), runoff is only 1 to 6 inches, probably reflecting a higher infiltration rate for the surficial sediments. Along the beach ridge in this area, the surficial aquifer system receives local recharge from rainfall, and is also recharged by upward leakage from the underlying Upper Floridan aquifer. The rate of upward leakage is thought to be very low because the sediments between the surficial aquifer system and the Upper Floridan aquifer have low permeability.

Knochenmus and Beard (1971, p. 12) concluded that for the Upper Floridan aquifer "no area in Volusia County can be considered the principal recharge area." This statement was meant to counter the widely accepted misconception that Upper Floridan recharge occurs primarily in areas where the potentiometric surface of the Upper Floridan aquifer is relatively high. In Volusia County, the potentiometric-surface high of the Upper Floridan is at the western edge of the Talbot Terrace, not along the De Land Ridge, where the highest rates of recharge to the Upper Floridan occur. Knochenmus and Beard (1971) cited work by Visher and Wetterhall (1967) concluding that in the Floridan aquifer system, most potentiometric-surface highs are indicative of areas of low transmissivity and low, or rejected, recharge.

To summarize, recharge to the surficial aquifer system can occur wherever the surficial sediments have an unsaturated zone and are permeable. Thus, the recharge to the surficial aquifer takes place, at least locally, throughout much of the county. However, for recharge to enter the Upper Floridan aquifer, there must be a downward vertical hydraulic gradient between both zones of the surficial aquifer system and the Upper Floridan, and the sediments between the surficial aquifer system and the Upper Floridan must be permeable.

\section{Rates of Recharge}

Rates of recharge to a ground-water reservoir can be estimated using water budgets or by summing the rises portrayed in hydrographs. Computer-modeling studies by Bush (1978) and Tibbals (1981) provided the basis for a water budget of the surficial aquifer system described by Rutledge (1985a, table 4). He estimated that the rate of recharge in ridge areas of the county (western part) ranged from 10 to $18 \mathrm{in} / \mathrm{yr}$ (inches per year), whereas in terrace (nonridge) areas not in areas of artesian-flow in the Upper Floridan (central part of the county), the rate was about $4 \mathrm{in} / \mathrm{yr}$. In areas of artesian flow, he calculated that the surficial aquifer received about 4 in/yr of upward leakage from the Upper Floridan aquifer. Rutledge assumed that the residual water of the ground-water budget for the surficial aquifer system eventually reached the Upper Floridan 
aquifer; that is, net recharge to the surficial aquifer system equals discharge (flowthrough) to the Upper Floridan.

During this study, rates of recharge to the surficial aquifer system were estimated using hydrograph data from three wells tapping the upper permeable zone (locations are shown in fig. 12) of the surficial aquifer system. The analysis utilized a method described by Rasmussen and Andreasen (1959, p. 94-95) in which recharge is estimated by summing the rises in ground-water stage and multiplying the result by the gravity yield (specific yield). As mentioned by Rasmussen and Andreasen (1959, p. 94), this estimate falls short of the true recharge by the amount of groundwater drainage occurring during the rise. A specific yield $\left(\mathrm{S}_{\mathrm{y}}\right)$ of 0.25 was estimated by Knochenmus and Beard (1971, p. 31) and probably represents an upper limit. A minimum value of $S_{y}$ is estimated to be 0.10 . Because of the detailed data available, hydrographs for wells 43,71 , and 111 for 1966-69 were analyzed. An example of the use of this method is shown for well 43 in figure 16 . The calculated recharge is as follows:

Recharge, inches

\begin{tabular}{|c|c|c|c|c|c|c|}
\hline \multirow[b]{2}{*}{ Time interval } & \multicolumn{2}{|c|}{ Well 43} & \multicolumn{2}{|c|}{ Well 71} & \multicolumn{2}{|c|}{ Well 111} \\
\hline & $5 y=0.25$ & $S y=0.10$ & Sy $=0.25$ & $S y=0.10$ & $5 y=0.25$ & $S y=0.10$ \\
\hline $5-66$ to $4-67$ & 16.05 & 6.42 & 20.10 & 8.04 & 18.60 & 7.44 \\
\hline $5-67$ to $4-68$ & 7.05 & 2.82 & 15.60 & 6.24 & 21.60 & 8.64 \\
\hline $5-68$ to $4-69$ & 28.80 & 11.52 & 22.50 & 9.00 & 27.60 & 11.04 \\
\hline
\end{tabular}

Rainfall at De Land was 50.07 inches for May 1966 to April 1967, 40.22 inches for May 1967 to April 1968, and 68.83 inches for May 1968 to April 1969. The recharge calculated for $S_{y}=0.25$ thus ranged from about 17 to 54 percent of rainfall and, for $S_{y}=0.10$, from 7 to 21 percent of rainfall. At well 43 , located in a basin with no surface runoff, evapotranspiration can be estimated by subtracting the recharge rate from the rainfall (assuming that there is no horizontal ground-water outflow). For May 1966 to April 1967, estimated evapotranspiration was about 34 inches for $S_{y}=0.25$ and 44 inches for $S_{y}=0.10$; for May 1967 to April 1968 about 33 inches for $S_{y}=0.25$ and 37 inches for $S_{y}=0.10$; and for May 1968 to April 1969 was about 40 inches for $S_{y}=0.25$ and 57 inches for $S_{y}=0.10$. At well 43 , the evapotranspiration rate estimated by this method and assuming a value of $S_{y}$ of 0.25 is similar to the 38 to 39 inchès estimated by Rutledge (1985a, table 4). For $S_{y}=0.25$, the arithmetic mean of the three annual recharge rates calculated is $17 \mathrm{in} / \mathrm{yr}$ at well 43 .

At wells 71 and 111, runoff must also be considered because the wells are in basins that produce runoff. Rutledge (1985a, p. 36) reports that streamflow in Volusia County is mostly outflow from the surficial aquifer system. Recharge rates calculated using $S_{y}=0.25$ are high, so the estimate of $S_{y}$ $=0.10$ may be more accurate at those sites. Mean recharge rates based on that figure are about $8 \mathrm{in} / \mathrm{yr}$ and $9 \mathrm{in} / \mathrm{yr}$ for wells 71 and 111, respectively. Other factors influencing the relatively high recharge rates calculated include differences in vegetation type, nonrepresentative rainfall data because precipitation can vary widely from one area to another due to extremely localized convection thunderstorms during the summer, or because the assumption of no horizontal ground-water outflow is not correct.

Recharge enters the surficial aquifer system throughout much of Volusia County. The highest rates of recharge occur in the ridge areas having no surface drainage, in the western part of the county. Locally, recharge rates in that area can range from 6 to $18 \mathrm{in} / \mathrm{yr}$ (Tibbals, 1981, fig. 8; Rutledge, 1985a, table 4), which compare favorably to the $17 \mathrm{in} / \mathrm{yr}$ calculated at well 43 . The ridge areas without surface drainage occupy about 16 percent of the county. In the ridge areas, most of the recharge to the surficial aquifer system moves quickly downward to the Upper Floridan aquifer.

Substantial recharge also occurs on the Talbot and Pamlico Terraces. Although the terraces are not as conducive to recharge as the ridges (the downward vertical groundwater gradient is very slight, the unsaturated zone is thin, and the permeability of the underlying sediments ranges considerably), the terraces cover about 50 percent of the county. A recharge rate of 8 or $9 \mathrm{in} / \mathrm{yr}$ is estimated for the terrace areas. Recharge also occurs in ridge areas with surface drainage, but because such areas account for only about 6 percent of the county, the amount of recharge occurring there is much less significant than in other areas.

Recharge to the surficial aquifer system also occurs along the coastal ridges in the eastern part of the county at rates that can be as high as $10 \mathrm{in} / \mathrm{yr}$, but because the areas of this recharge are small and localized, recharge amounts are not significant. In the coastal ridges, the surficial aquifer system also receives recharge by upward leakage from the Upper Floridan aquifer. Recharge rates for the surficial aquifer system can be summarized as follows:

\begin{tabular}{|c|c|c|c|}
\hline \multirow[b]{2}{*}{ Area type } & \multirow{2}{*}{$\begin{array}{l}\text { Approximate } \\
\text { area }\left(\mathrm{mi}^{2}\right)\end{array}$} & \multicolumn{2}{|c|}{ Estimated recharge rate } \\
\hline & & (in/yr) & $(\mathrm{Mgal} / \mathrm{d})$ \\
\hline Artesian flow from Upper Floridan & 336 & $0-4$ & $0-64$ \\
\hline Terraces & 600 & $8-9$ & $228-257$ \\
\hline Ridges without surface drainage & 192 & $6-18$ & $55-165$ \\
\hline Ridges with surface drainage & 72 & $9-10$ & $31-34$ \\
\hline
\end{tabular}

\section{Hydraulic Characteristics of the Surficial Aquifer System}

The hydraulic characteristics of the surficial aquifer system in Volusia County vary with the lithology. The lithology, in turn, is very heterogeneous because the materials were deposited during cyclic transgressions and regressions of the sea. Knochenmus and Beard (1971, p. 9) concluded that "it appears that the variation in vertical permeability is as great from site to site within the same physiographic division as between sites within different physiographic divisions." Hydraulic characteristics of an aquifer can be determined by both laboratory and field techniques. Each method has certain advantages and disadvantages. 


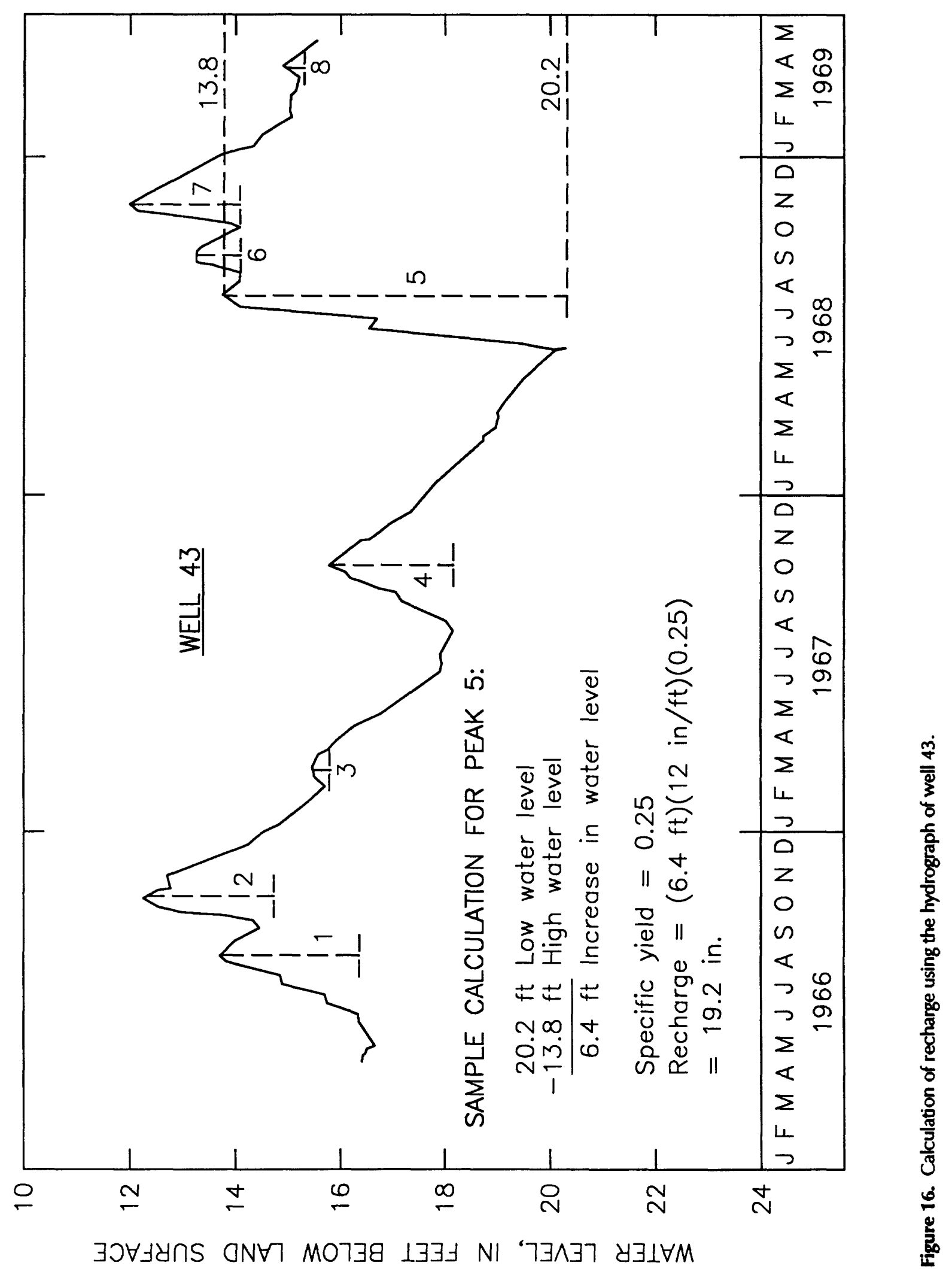




\section{Laboratory Determinations of Hydraulic Conductivity}

Core samples collected in the field can be analyzed in a laboratory to determine their hydraulic conductivity. Laboratory conductivities tend to be lower than field determinations for several reasons. Sediments containing more permeable materials tend to be distorted during coring and probably are further disturbed during transit to the laboratory. The coring process itself can cause compaction of the materials, thereby reducing the permeability of the core sample. Finally, samples of more permeable material often cannot be recovered during the coring process, so those cores that are analyzed tend to be biased toward lower permeability.

Kimrey (1990) described hydraulic characteristics of samples from 14 core holes in central Volusia County. The locations of these core holes are shown in figure 5; the laboratory-determined hydraulic characteristics for 11 clay samples from the core holes are given in table 5. Hydraulic conductivities range from $7.6 \times 10^{-5}$ to $3.4 \times 10^{-1} \mathrm{ft} / \mathrm{d}$ with a median of $1.0 \times 10^{-2} \mathrm{ft} / \mathrm{d}$. The least permeable sample came from a clay layer less than 1 foot thick. In core hole 7, a zone of clay with a laboratory hydraulic conductivity of $1.1 \times 10^{-4} \mathrm{ft} / \mathrm{d}$ was about 9 feet thick. Kimrey (1990), reported that, in general, the clay layers could not be correlated from hole to hole, and thus, concluded that confining units within, and at the base of the surficial aquifer system, are not continuous.

If several laboratory hydraulic conductivities are available for various samples in a single borehole, the true hydraulic conductivity of the formation can be estimated by techniques described by Bouwer (1978, p. 131-133). In heterogeneous material, such as is found in the surficial aquifer system, the permeability distribution appears to be random and the average hydraulic conductivity of the formation should be determined using the geometric mean, rather than using one value for the entire sequence or using the arithmetic mean of several values.

\section{Field Determinations of Hydraulic Conductivity}

Field hydraulic conductivity values are generally determined by some type of aquifer testing technique which can range from a simple slug test of a single well to a more complex aquifer test using a pumped well and several observation wells.

Slug injection tests were made by the St. Johns River Water Management District on some test wells drilled during this study and on some test wells drilled by the Water Management District. The slug test involves the instantaneous injection (or withdrawal) of a slug of water into (or from) a well. The resulting drop (or recovery) in water level is measured and a field value of hydraulic conductivity calculated. The well should be fully developed and open to the full thickness of the aquifer being tested. It
Table 5. Laboratory hydraulic conductivities for selected core samples in Volusia County

[Core hole numbers refer to figure 5 ; $\mathrm{f} / \mathrm{d}$, feet per day; modified from Kimrey, 1990]

\begin{tabular}{|c|c|c|c|}
\hline $\begin{array}{l}\text { Core } \\
\text { hole No. }\end{array}$ & $\begin{array}{l}\text { Depth } \\
\text { (feet) }\end{array}$ & Description of core sample & $\begin{array}{c}\text { Average hydraulic } \\
\text { conductivity, } \mathrm{K}(\mathrm{ft} / \mathrm{d})\end{array}$ \\
\hline 3 & $44-49$ & $\begin{array}{l}\text { Bluish-gray plastic clay, with } \\
\text { traces of brown-gray fine sand } \\
\text { inclusions. }\end{array}$ & $2.4 \times 10^{-1}$ \\
\hline 7 & $32-33$ & $\begin{array}{l}\text { Bluish-gray sandy clay with } \\
\text { traces of shell fragments }\end{array}$ & $3.4 \times 10^{-1}$ \\
\hline 7 & $20-29$ & $\begin{array}{l}\text { Gray plastic clay with traces } \\
\text { of shell fragments }\end{array}$ & $1.1 \times 10^{-4}$ \\
\hline 8 & 62.63 & Bluish-gray plastic clay & $2.6 \times 10^{-3}$ \\
\hline 8 & $69-70$ & $\begin{array}{l}\text { Light gray slightly clayey fine } \\
\text { sand with fine shell fragments }\end{array}$ & $3.6 \times 10^{-2}$ \\
\hline 9 & 64.65 & $\begin{array}{l}\text { Light gray slightly clayey fine } \\
\text { sand with traces of shell } \\
\text { fragments }\end{array}$ & $2.2 \times 10^{-2}$ \\
\hline 10 & $31-33$ & $\begin{array}{l}\text { Bluish-gray plastic clay with } \\
\text { large limestone inclusions }\end{array}$ & $8.1 \times 10^{-3}$ \\
\hline 11 & $52-53$ & $\begin{array}{l}\text { Bluish-gray clay with small } \\
\text { horizontal sand lenses, } \\
\text { (brittle as received) }\end{array}$ & $1.0 \times 10^{-2}$ \\
\hline 12 & $46-47$ & $\begin{array}{l}\text { Bluish-gray sandy clay with } \\
\text { traces of shell fragments }\end{array}$ & $7.6 \times 10^{-5}$ \\
\hline 13 & $36-37$ & $\begin{array}{l}\text { Greenish-gray clay (slightly } \\
\text { brittle as received) }\end{array}$ & $7.8 \times 10^{-4}$ \\
\hline 14 & $80-81$ & $\begin{array}{l}\text { Greenish-gray clay (brittle } \\
\text { as received) }\end{array}$ & $1.0 \times 10^{-2}$ \\
\hline
\end{tabular}

is important to note that the test generally applies only to the material close to the well and indiscriminate use of the results can lead to erroneous conclusions (Ferris and Knowles, 1963, p. 299).

Field hydraulic conductivities determined by McGurk and others (1989) are shown in table 6. The values range from $3 \times 10^{-2}$ to $12.8 \mathrm{ft} / \mathrm{d}$ with a median of $2.9 \times 10^{-1} \mathrm{ft} / \mathrm{d}_{2}$ much higher than the laboratory values in table $5\left(7.6 \times 10^{-5}\right.$ to $3.4 \times 10^{-1} \mathrm{ft} / \mathrm{d}$ ), primarily because the slug tests measured the hydraulic conductivities of the more permeable strata of the surficial aquifer system, whereas the laboratory tests (as discussed previously) measured the hydraulic conductivity of the least permeable strata.

In a repeat test on each of two wells, the calculated hydraulic conductivity values differed by an order of magnitude. Although it is not known whether such 
variability would be observed in the other wells, on the basis of these tests, it appears that the range of error in the slug tests may be one order of magnitude.

Table 6. Field hydraulic conductivities for wells in Volusia County

[Data from McGurk and others, 1989. Well or site numbers refer to table 1 and figure 6. Aquifer zone: U, upper permeable zone; $L$, lower permeable zone; $\mathrm{ft} / \mathrm{d}$, feet per day]

\begin{tabular}{|c|c|c|c|}
\hline $\begin{array}{c}\text { Well or } \\
\text { site No. }\end{array}$ & $\begin{array}{c}\text { Interval tested } \\
\text { (feet) }\end{array}$ & $\begin{array}{c}\text { Aquifer } \\
\text { zone }\end{array}$ & $\begin{array}{c}\text { Hydraulic } \\
\text { conductivity } \\
\text { (ft/d) }\end{array}$ \\
\hline 206, V0185 & $20-30$ & $\mathrm{U}$ & $\begin{array}{l}1.0 \times 10^{-1} \\
4.5 \times 10^{-2}\end{array}$ \\
\hline V0354 & $55-75$ & L & $\begin{array}{l}1.0 \\
2.1 \times 10^{-1}\end{array}$ \\
\hline 123, V0372 & $62-72$ & $\mathrm{~L}$ & $3.0 \times 10^{-2}$ \\
\hline 122, v0360 & $32-42$ & $\mathrm{U}$ & $1.5 \times 10^{-1}$ \\
\hline V0356 & $45-65$ & L & 7.7 \\
\hline V0357 & $48-58$ & $\vec{L}$ & 3.1 \\
\hline V0193 & $16-40$ & $\mathrm{U}$ & $1.9 \times 10^{-1}$ \\
\hline V0361 & $53-73$ & $\mathrm{~L}$ & 1.0 \\
\hline V0363 & $50-69$ & $\mathrm{~L}$ & $1.7 \times 10^{-1}$ \\
\hline V0364 & $53-73$ & L & $2.9 \times 10^{-1}$ \\
\hline 30, V0197 & $20-30$ & $\mathrm{U}$ & $2.2 \times 10^{-1}$ \\
\hline V0368 & $40-60$ & L & $4.0 \times 10^{-1}$ \\
\hline 4, V0369 & $57-70$ & L & 1.7 \\
\hline v0370 & $50-60$ & L & 4.8 \\
\hline V0371 & $0-20$ & $\mathrm{U}$ & 12.8 \\
\hline V0373 & $20-40$ & $\mathrm{U}$ & $5.2 \times 10^{-1}$ \\
\hline
\end{tabular}

\section{Aquifer Tests}

\section{Results from earlier studies}

Perhaps the most representative method, but also the most complicated and labor intensive one, of determining field values of hydraulic parameters is by an aquifer test, in which a well is pumped and the drawdown and recovery of water levels in one or more observation wells, are recorded and analyzed.

Gomberg $(1980,1981)$ performed numerous aquifer tests in both the upper and lower permeable zones of the surficial aquifer system in northeastern Volusia County. He calculated transmissivity values for the upper zone ranging from less than 100 to more than $1,300 \mathrm{ft}^{2} / \mathrm{d}$, and concluded that the variations were caused mostly by variations in the thickness of the permeable zone. Hydraulic conductivities estimated from Gomberg's data for the upper permeable zone ranged from about 4 to $110 \mathrm{ft} / \mathrm{d}$. Transmissivities for the lower zone ranged from less than 300 to more than
$9,300 \mathrm{ft}^{2} / \mathrm{d}$. Hydraulic conductivities calculated from these aquifer tests ranged from 28 to $49 \mathrm{ft} / \mathrm{d}$. The large range in transmissivity values for the lower zone is caused by variations in thickness of the aquifer and in permeability, which results from lithologic variations (Gomberg, 1980, p. v). Sediments containing more silt and clay have lower transmissivities than those composed mostly of sand and shell. No other aquifer tests for the surficial aquifer system were found in the existing literature because most past studies of the water resources of Volusia County have concentrated on the Floridan aquifer system.

\section{Oak Hill aquifer test}

In the Oak Hill area of southeastern Volusia County (fig. 1), the water in the Upper Floridan aquifer is not potable because of high chloride concentration. Therefore, most of the water supply for the area is withdrawn from domestic wells that tap the lower zone of the surficial aquifer system.

An exploratory auger boring was drilled in the area and the lithology of the sediments encountered was as follows:

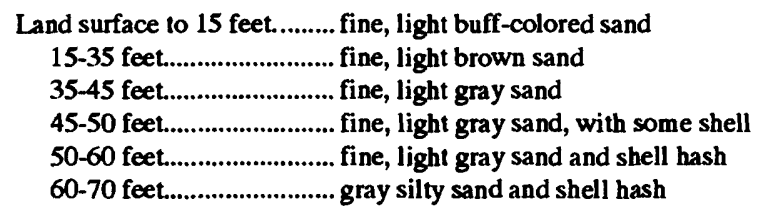

Because of the desire not to penetrate the confining layer between the surficial sediments and the Upper Floridan aquifer, drilling was stopped at 70 feet below land surface. Based on information about the casing depths of wells in the area which penetrate the Upper Floridan, it is estimated that the bottom of the lower permeable zone is no more than 75 to 80 feet below land surface. Thus, based on test drilling and the natural gamma $\log$ of well 14 in figure $9 \mathrm{a}$, the thickness of the lower zone at the site is about 35 to 40 feet.

Four pairs of wells were drilled near the Oak Hill Town Hall (fig. 17). A 6-inch production well (well 285129080510501) was completed into the lower permeable zone. The well was drilled using the mud-rotary method and completed with a wire-wound plastic screen from 50 to 60 feet below land surface. The screen was gravel packed and the well was developed by surging and with compressed air. Twenty feet to the east of the production well, a 6-inch well was drilled (well 285129080510502), also by mud rotary, and a plastic casing with a wire-wound plastic screen emplaced at a 20- to 30-foot depth was installed and gravel packed. Development was similar to that for the production well. Three pairs of 2-inch diameter observation wells were augered at distances of 126, 154, and 250 feet (fig. 17). Each pair was composed of a 60 -foot deep well screened from 50 to 60 feet, and a 30-foot deep well screened at the 20- to 30-foot depth. The observation wells were developed with compressed air. 


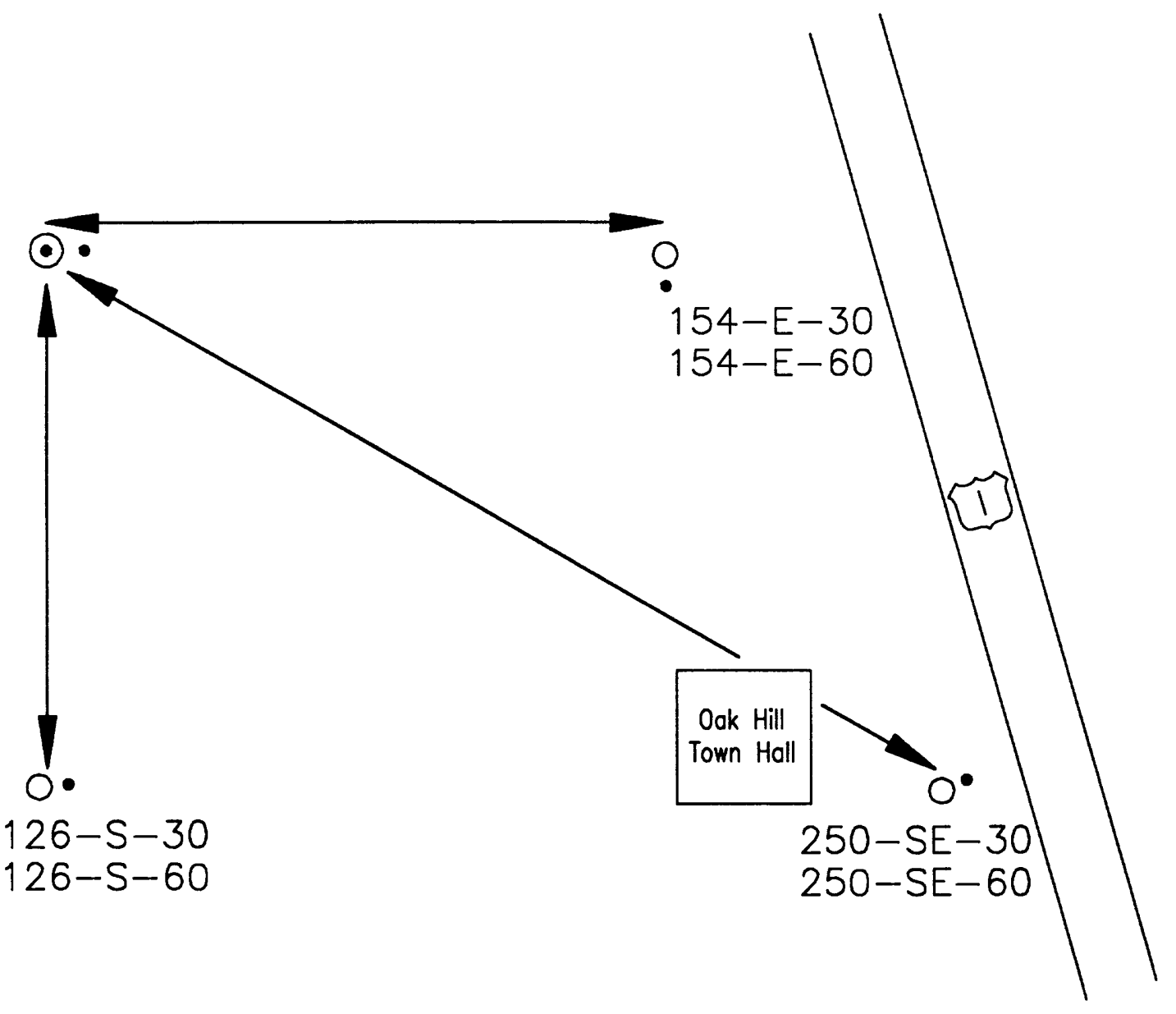

EXPLANATION

- PUMPED WELL

OBSERVATION WELL,

60 feet deep

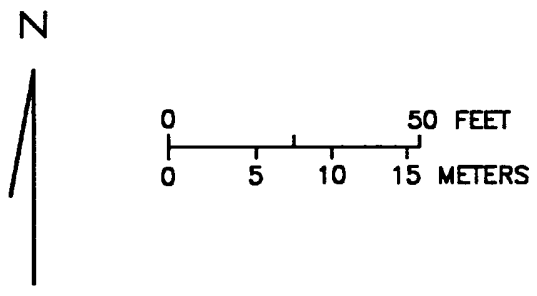

- observation well, 30 feet deep

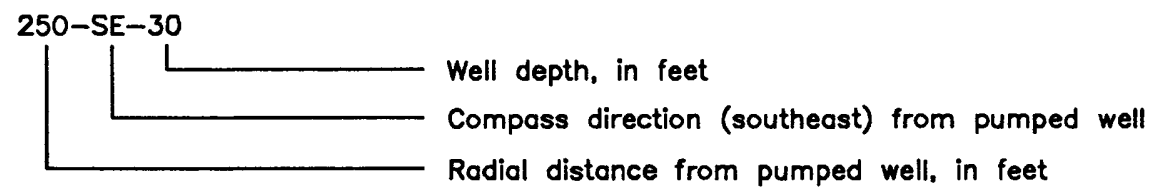

Figure 17. Sketch of Oak Hill aquifer test site. 
Water levels in the well pairs during nonpumping periods are given in table 7 . The mean difference in depth to water between the upper and lower zones is about 1 foot. Although the natural gamma $\log$ in figure 9 a does not show the presence of a high gamma-activity clay layer between the upper and lower zones, the fine sand and silt found at the site apparently provide sufficient confinement to separate the two zones, based on the data collected while pumping the lower zone.

Table 7. Depth to water in well pairs at Oak Hill test site

[Datum is land surface; depth is in feet; -- indicates no data]

Date

Well

$\begin{array}{lllll}02-26-87 & 03-03-87 & 03-04-87 & 09-14-87 & 09-17-87\end{array}$

\begin{tabular}{lrrrll}
285129080510501 & 8.46 & 8.45 & 8.63 & -- & 9.79 \\
285129080510502 & 6.60 & 7.39 & 7.35 & 8.74 & 8.27 \\
Difference & 1.86 & 1.06 & 1.28 & \multicolumn{1}{l}{--} & 1.52 \\
& & & & & \\
154-E-60 & 6.80 & 8.22 & 8.45 & 9.69 & 8.43 \\
154-E-30 & 6.32 & 7.43 & 7.50 & 8.34 & 7.00 \\
Difference & .48 & .79 & .95 & 1.35 & 1.43 \\
& & & & & \\
250-SE-60 & 7.65 & 6.51 & 6.68 & 8.06 & 8.93 \\
250-SE-30 & 7.06 & 5.92 & 5.90 & 6.84 & 7.76 \\
Difference & .59 & .59 & .78 & 1.22 & 1.17 \\
& & & & & \\
125-S-60 & 10.12 & 10.09 & 10.26 & 11.54 & 11.40 \\
125-S-30 & 9.37 & 9.36 & 9.36 & 10.80 & 10.39 \\
Difference & .75 & .73 & .90 & .74 & 1.01 \\
& & & & & \\
\hline
\end{tabular}

An aquifer test was conducted on March 4-5, 1987. The production well was pumped at $50 \mathrm{gal} / \mathrm{min}$ (gallons per minute) for about 19 hours. The response of the upper permeable zone to pumping the lower permeable zone was slight. In well 285129080510502,20 feet east of the production well and 30 feet deep, the water level dropped about 0.05 foot after 5 minutes of pumping, remained steady for about 8 hours of pumping, and slowly retumed to static level. In well 154-E-30, the water level slowly rose about 0.03 foot during the entire test. In well 250 -SE-30, the level fell 0.05 foot and was slowly rising when the test ended after 19 hours of pumping. In well 126-S-30, the water level rose, then fell, then rose, with a fluctuation of about 0.04 foot (see fig. 17).

The maximum drawdowns in the lower permeable zone observation wells were: well 154-E- $60,0.79$ foot; well 250-SE-60, 0.68 foot; and well 126-S-60, 1.33 feet. Variations in the drawdowns appear to be caused not only by differences in distance from the pumped well but perhaps also by anisotropy in the aquifer, probably caused by the heterogeneity of the sediments due to the depositional environment, and by the fact that all the wells did not fully penetrate the lower zone.
The aquifer test data were analyzed using Jacob's (1946) method, a curve-matching technique using the modified Bessel function. The method is applicable to leaky aquifers which have reached steady state. Figure 18a shows plots of drawdown against time for the three observation wells which indicate that steady state had been reached late in the test. To calculate transmissivity using Jacob's method, drawdown at each observation well was plotted against its respective distance from the production well at some time after steady state had been reached, in this case, 615 minutes into the test. A best fit to the Bessel function curve was made and, using the value of the Bessel function at the match point, a transmissivity of $1,200 \mathrm{ft}^{2} / \mathrm{d}$ was calculated. Assuming a thickness of the lower zone of 35 to 40 feet, this corresponds to a hydraulic conductivity of about $30 \mathrm{ft} / \mathrm{d}$. Figure $18 \mathrm{~b}$ shows the calculation of transmissivity.

The lower zone of the surficial aquifer receives leakage from above and below, so a leakance value was not calculated because the effects of the two sources of leakage cannot be separated with the data from this test.

Because the underlying Upper Floridan aquifer contains salty water, the specific conductance of water from the production well was monitored during the test. Before the test began, the specific conductance of the water was $575 \mu \mathrm{S} / \mathrm{cm}$ (microsiemens per centimeter) at $25^{\circ}$ Celsius. After 15 hours of pumping, the specific conductance had risen to $720 \mu \mathrm{S} / \mathrm{cm}$ and after 19 hours to $800 \mu \mathrm{S} / \mathrm{cm}$. If large-scale production of water from wells completed into the lower zone of the surficial aquifer in the Oak Hill area is contemplated, a long-term test to monitor changes in water quality would be useful.

\section{QUALITY OF WATER}

Previous studies of the ground water resources of Volusia County (Knochenmus and Beard, 1971) and Rutledge (1985a) did not address the chemical quality of water in the surficial aquifer system in detail and most discussions of water quality emphasized the chloride concentration in the water. During this study, 52 wells were sampled for major constituents, trace elements, and nutrients using techniques documented by Wood (1976) and Skougstad and others (1979). At 12 locations, both the upper and lower permeable zones were sampled. The locations of wells sampled are shown in figure 19.

\section{Upper Permeable Zone}

Water from 39 wells tapping the upper permeable zone of the surficial aquifer system were sampled in 1987. Physical characteristics, major constituents, and trace elements of the water samples are given in table 8, and nutrient concentrations in table 9. Also given in table 8 are chloride analyses of water collected by Rutledge (1985a) in 1982. 


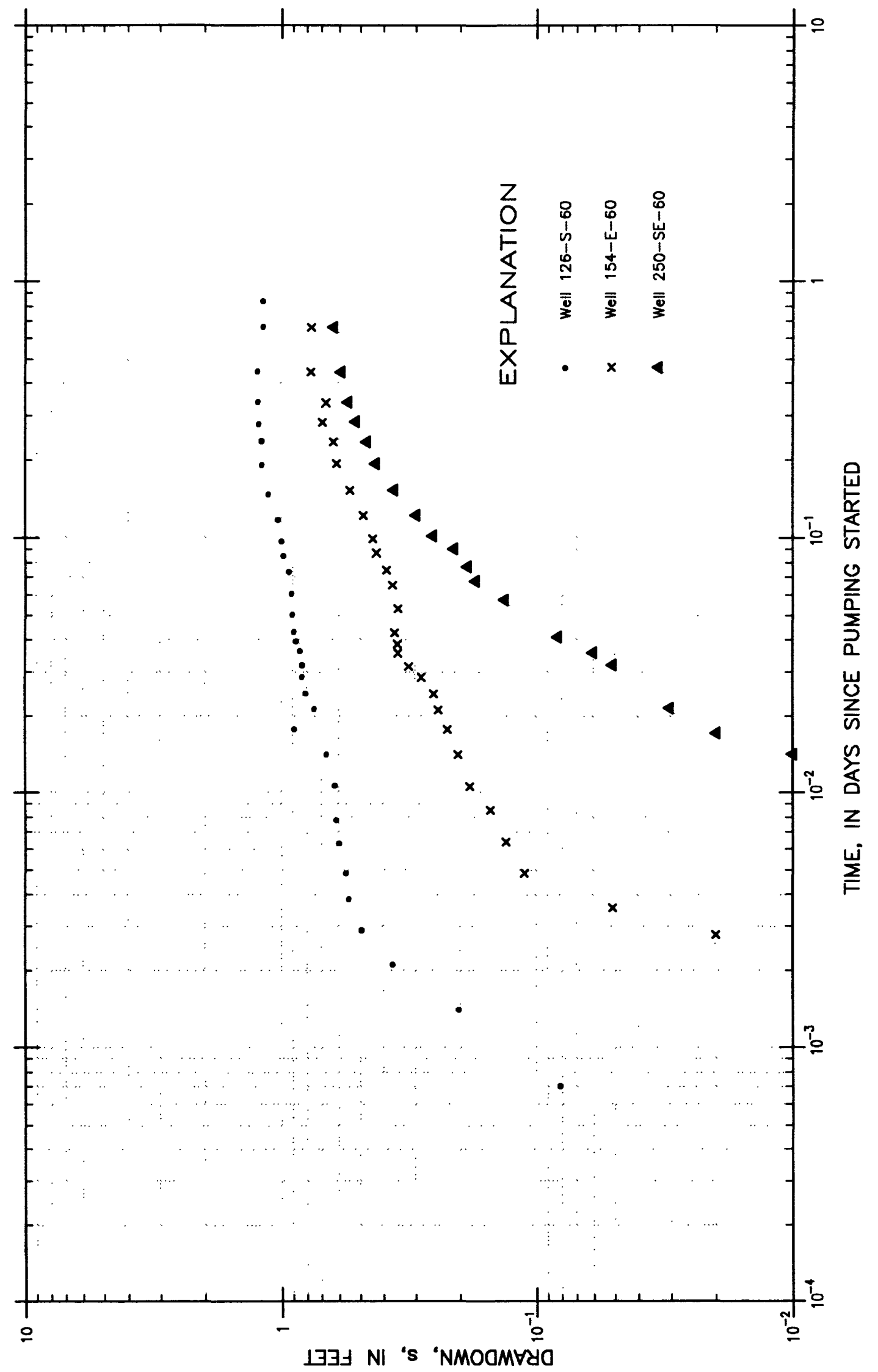

 


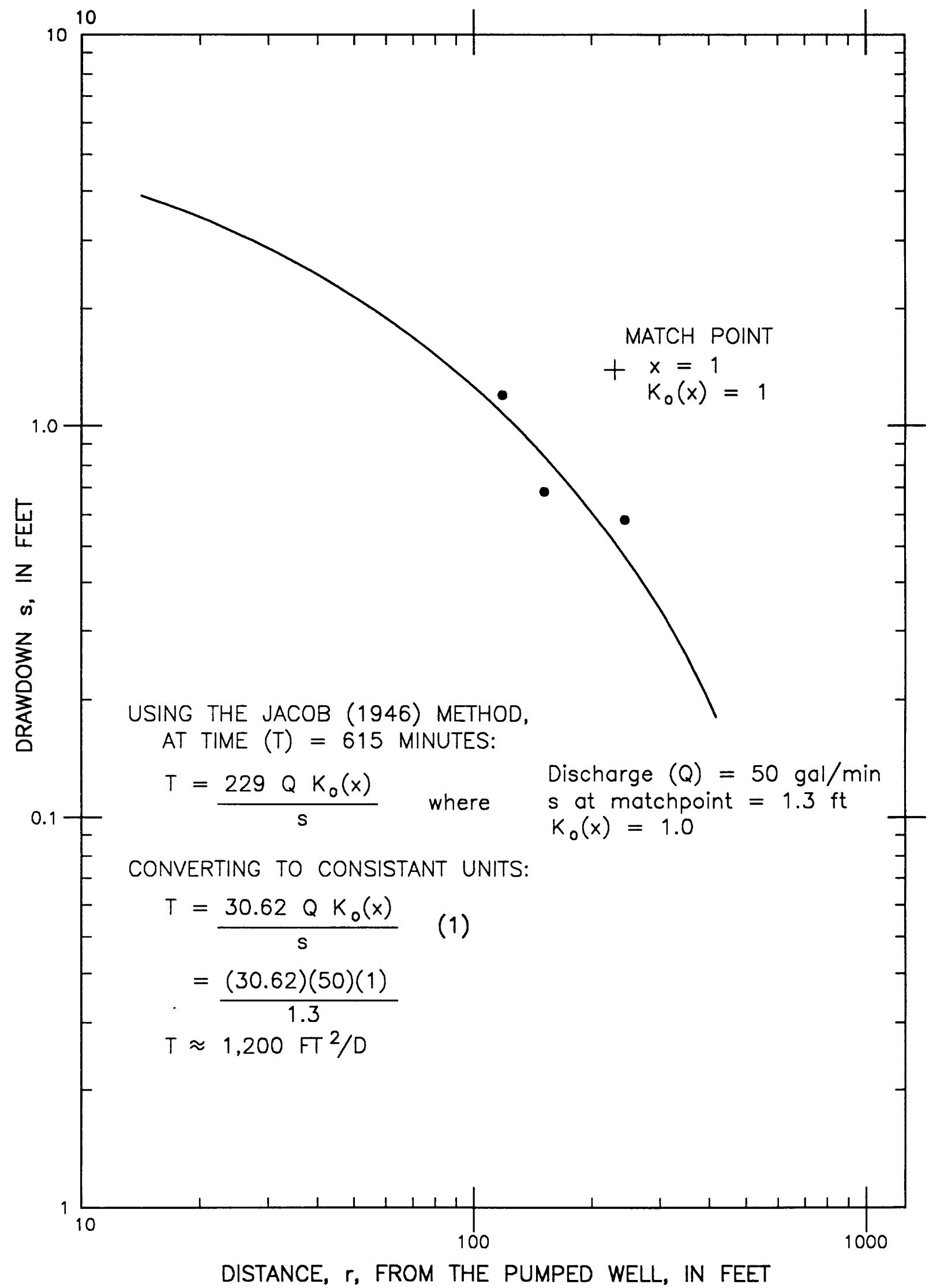

Figure 18b. Calculation of transmissivity of the lower permeable zone at Oak Hill. 


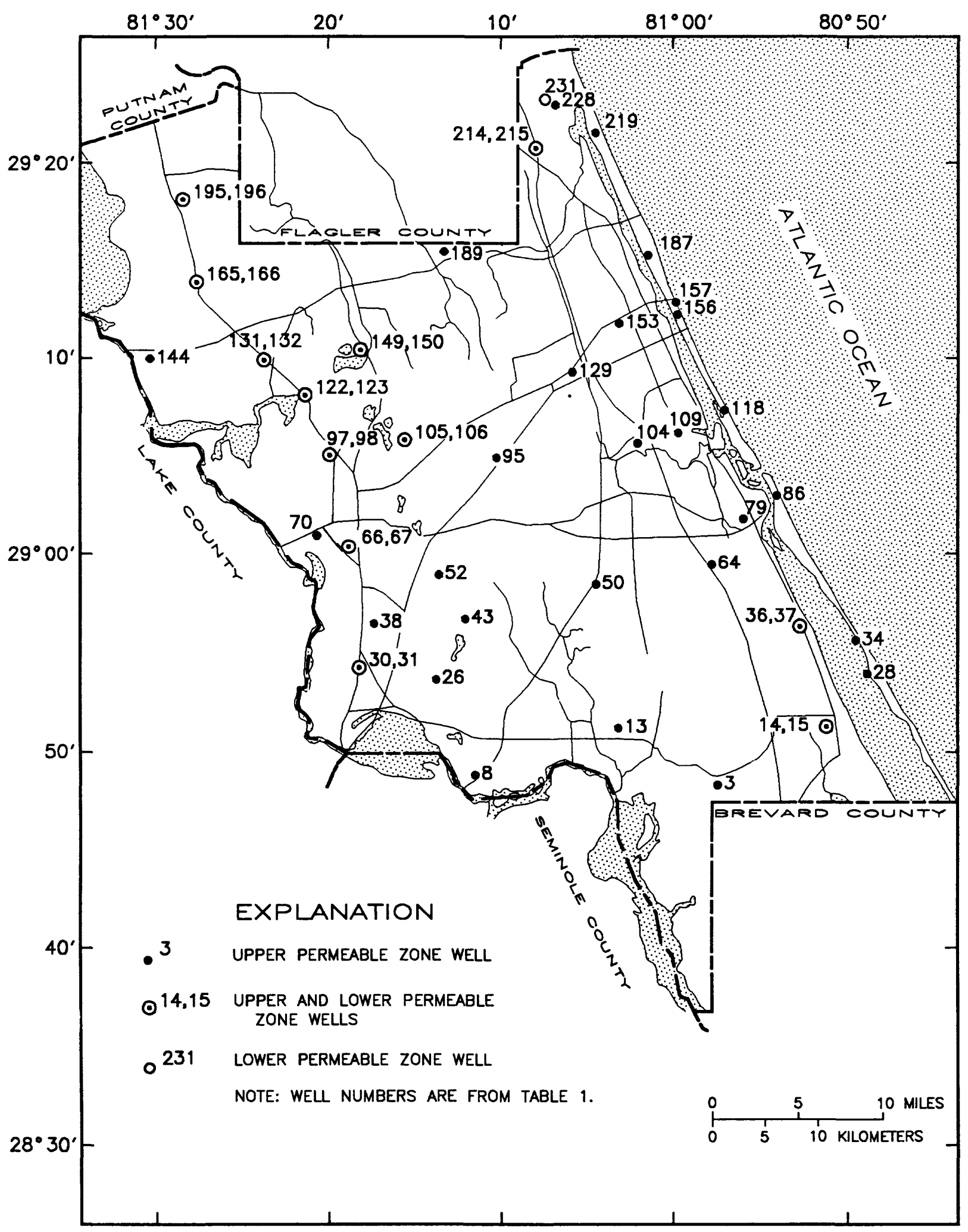

Figure 19. Locations of wells sampled during this study. 


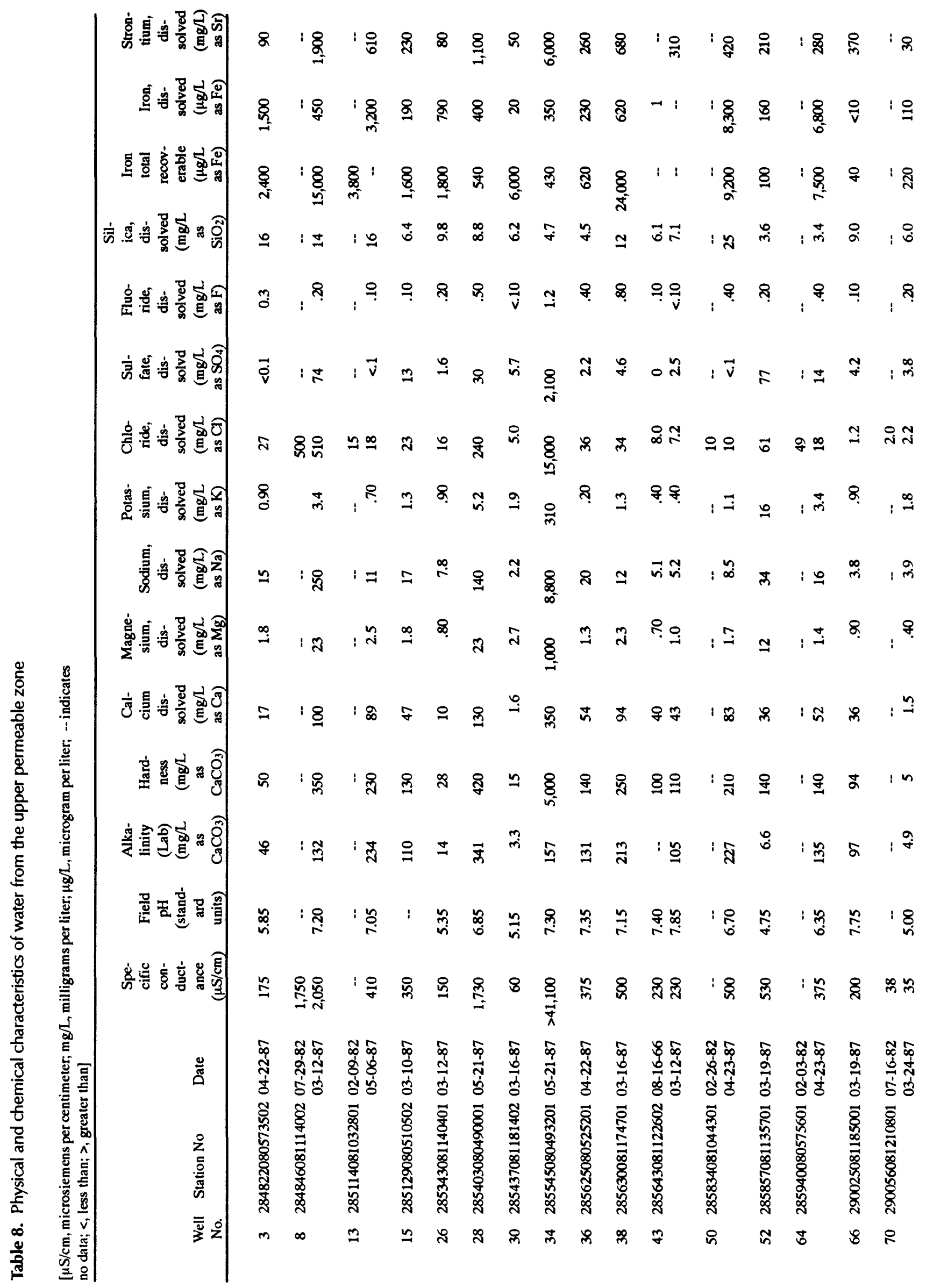




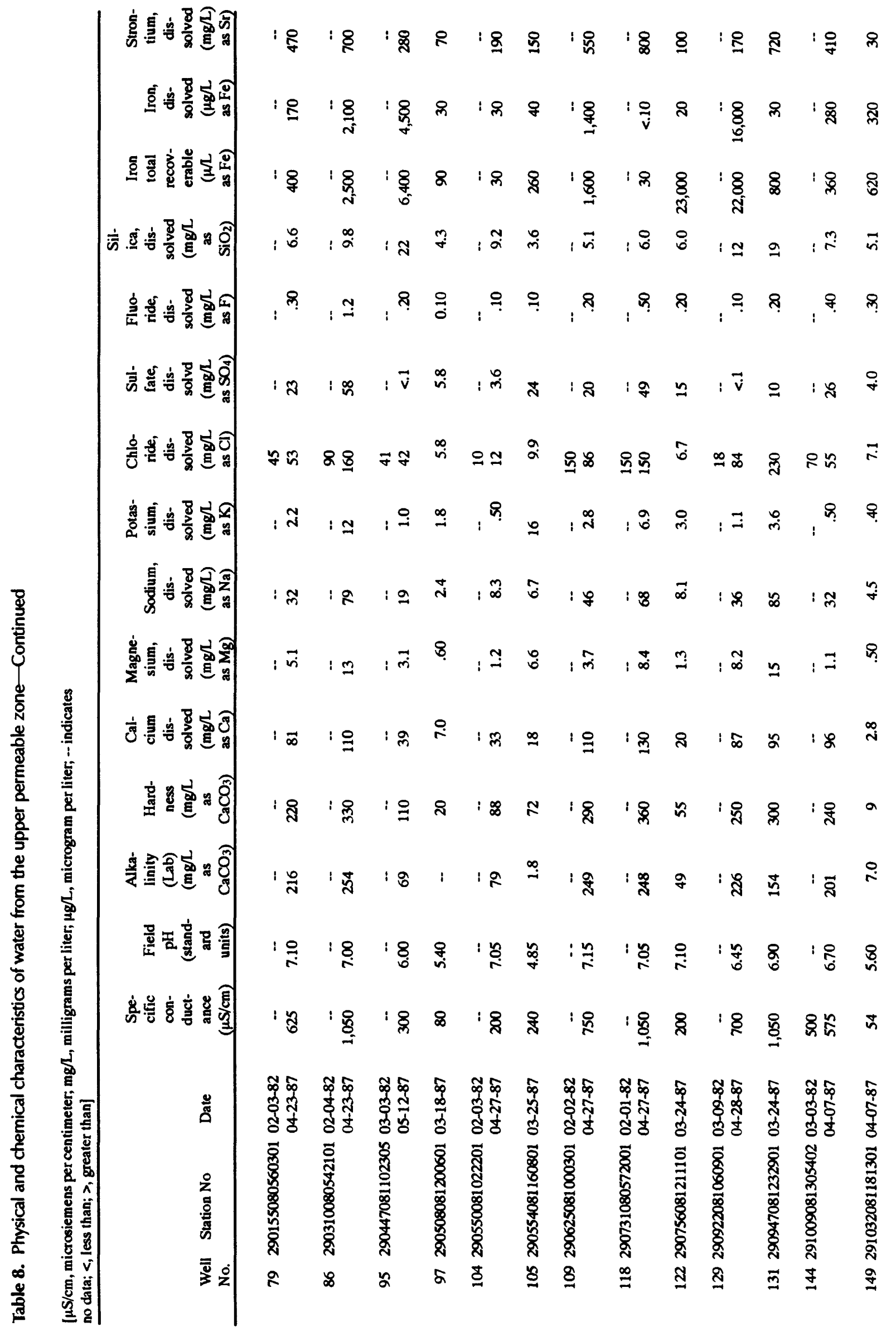




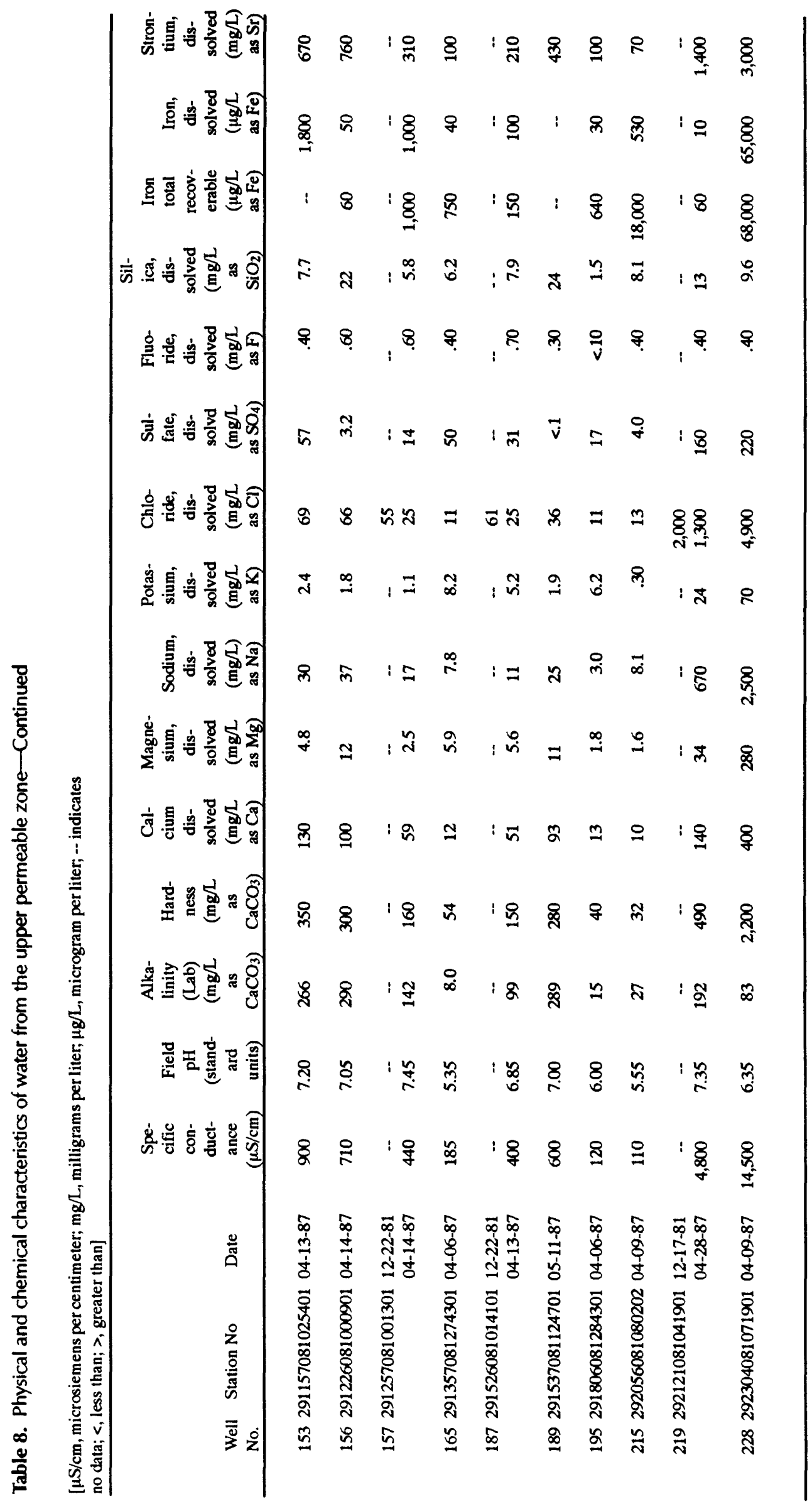


Table 9. Nutrient concentrations in water from the upper permeable zone

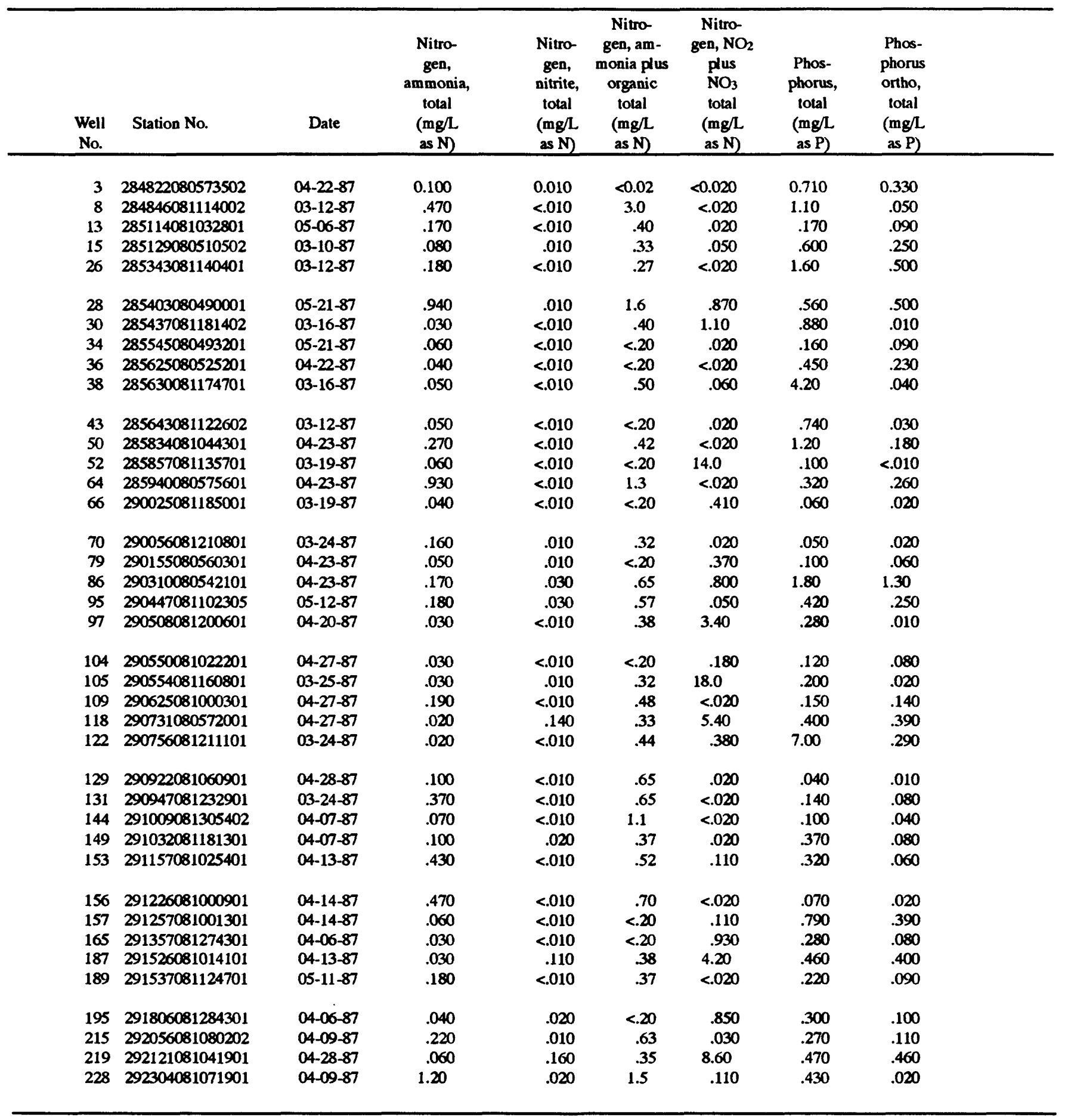

The specific conductance of water from the upper zone varied widely, from a minimum of $35 \mu \mathrm{S} / \mathrm{cm}$ at well 70 , west of De Land, to more than $41,000 \mu \mathrm{S} / \mathrm{cm}$ at well 34 near the Atlantic Ocean. The highest chloride concentration in water from an upper zone well $(15,000 \mathrm{mg} / \mathrm{L}$ ) (milligrams per liter) was found at well 34, and the lowest $(1.2 \mathrm{mg} / \mathrm{L})$ at well 66 in De Land. The highest hardness of water from the upper zone was $5,000 \mathrm{mg} / \mathrm{Las}$ $\mathrm{CaCO}_{3}$ at well 34. The hardness at well 228 was $2,200 \mathrm{mg} / \mathrm{L}$ as $\mathrm{CaCO}_{3}$. Excluding those two sites, the mean hardness of water from upper zone wells was $140 \mathrm{mg} / \mathrm{L}$. Although wells along the St. Johns River and along the Atlantic coast tend to yield waters with high chloride concentrations and high specific conductances, insufficient data were available to draw any statistical correlations between well locations and chloride concentration or specific conductance. The general distribution of chloride in the upper permeable zone of the surficial aquifer system, updated from Rutledge (1985a) with data collected in 1987, are shown in figure 20. 


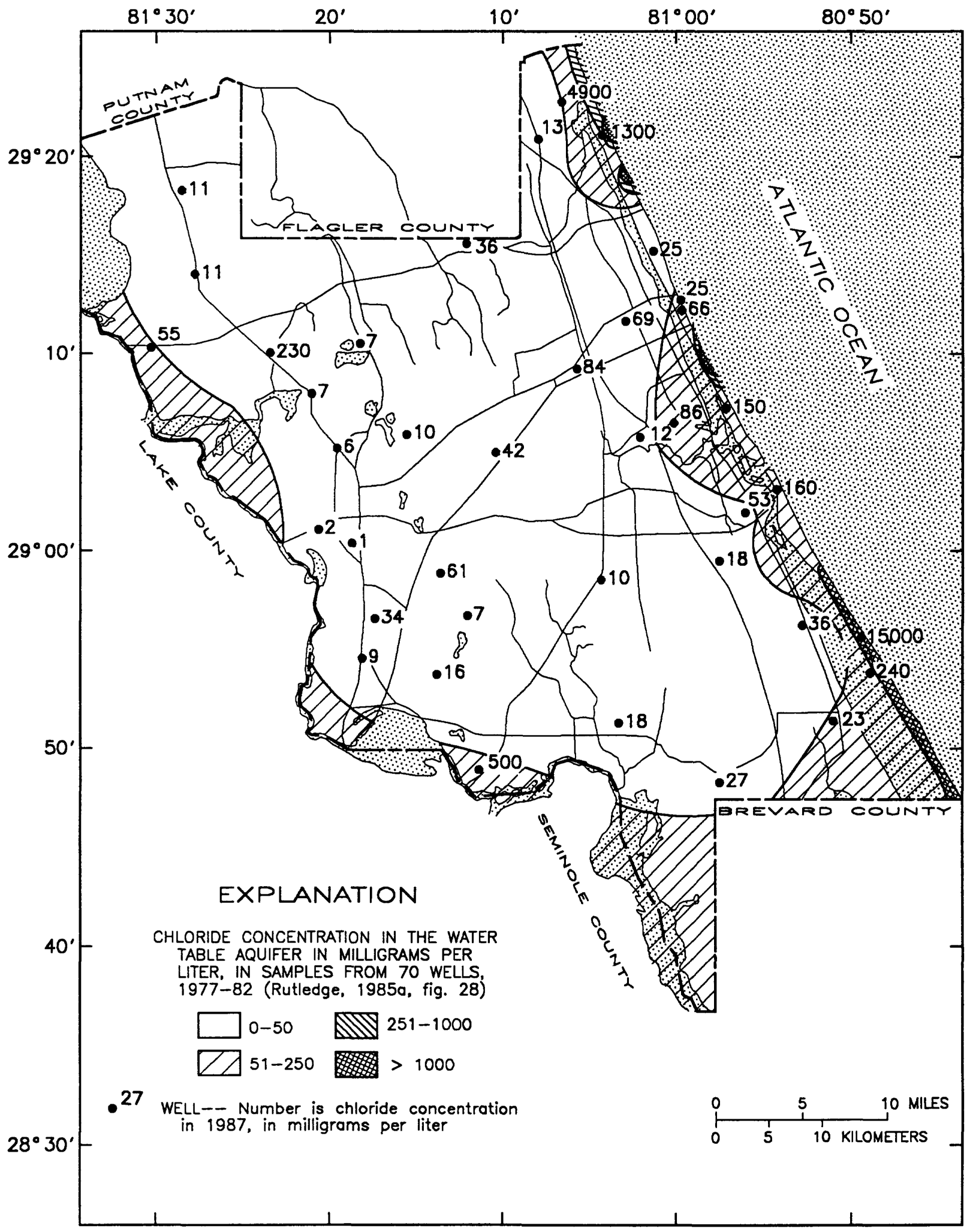

Figure 20. Distribution of chloride concentration in water from the upper permeable zone and concentrations from individual wells in 1987. 
The chloride concentrations at wells 52,95 , and $129(61$, 42 , and $84 \mathrm{mg} /$, respectively) are somewhat higher than might be expected. This might be because the wells are located in terrace areas with poorly developed surface drainage and because water leaves the upper zone mostly by evapotranspiration, eventually resulting in an increased concentration of dissolved constituents in the ground water. Local fertilizer application or highway runoff may also cause the high chloride concentrations. The chloride concentration of $230 \mathrm{mg} / \mathrm{L}$ at well 131 occurs because the site is topographically low, the surficial water-bearing sediments are thin, the vertical hydraulic gradient is upward, and the underlying Upper Floridan aquifer contains water with a chloride concentration greater than $250 \mathrm{mg} / \mathrm{L}$ (Rutledge, 1985a, fig. 30).

Chloride concentrations of water from some wells (for example, wells $64,86,109,157,187$, and 219) sampled during this study were significantly lower than in water samples collected in 1981-82 (table 8). This is probably due to the fact that recharge to the surficial aquifer system was reduced during the drought conditions which occurred in 1981 and early 1982. All of those wells are located on the Atlantic Coastal and Atlantic Beach Ridges. Some other wells (such as wells 8, 13, $43,50,70,79,95$, and 118) show little change in chloride concentration between 1981-82 and 1987. Most of those wells are located on inland ridges or terraces, except well 118 (fig. 19). The sample from well 129 had a higher chloride concentration in 1987 than in 1982, perhaps because the well was pumped longer before the sample was collected.

A trilinear diagram showing chemical composition can be useful in indicating similarities or differences in chemical water type (Hem, 1970, p. 268-269), although it does not show the differences in total ion concentrations. The presence of two geochemical facies is indicated by two distinct trends in the trilinear diagram for water samples from the upper zone (fig. 21). Samples from wells located on the De Land and Crescent City Ridges, shown by open circles in figure 21, form one geochemical facies. Chloride concentrations from the samples ranged from 1.2 to $34 \mathrm{mg} / \mathrm{L}$. All wells in that group were located at sites with land surface altitude greater than 35 feet above sea level, and the median land surface altitude for wells in the group was 65 feet. The remaining wells, located on the terraces, beach ridges, and in the St. Johns River Valley, yield water forming a second geochemical facies. The chloride concentration of water from this group of wells showed a wider variation than did the previous group. The median land surface altitude for the sites in the group was 29 feet above sea level. The two geochemical facies, thus, seem to be related to the physiographic location of the site. The sites on the De Land and Crescent City Ridges have been emergent for a longer period of time and have thus had a longer period of freshwater recharge from precipitation flushing out old seawater. The other group of sites, which generally are located at lower altitudes, have been inundated by the sea more frequently and more recently and, thus, the shallow ground water may show the effects of repeated cycles of mixing relict seawater with fresh rainwater.
Another constituent of interest is iron; high concentrations of iron give water an unpleasant taste and can stain plumbing fixtures, sidewalks, and buildings. Total iron in water from upper zone wells ranged from $30 \mu \mathrm{g} / \mathrm{L}$ (micrograms per liter) at well 104 to $68,000 \mu \mathrm{g} / \mathrm{L}$ at well 228 (table 8). The median concentration for all wells, except wells 34 and 228, was $800 \mu \mathrm{g} / \mathrm{L}$. Data on the dissolved iron concentration may be more useful than total iron because older wells with iron casings may yield water containing iron particles corroded from the casing and also because sand or clay suspended in turbid samples may contain significant amounts of iron. Dissolved iron ranged from $1.0 \mu \mathrm{g} / \mathrm{L}$ to $65,000 \mu \mathrm{g} / \mathrm{L}$ with a median (excluding wells 34 and 228) of $210 \mu \mathrm{g} / \mathrm{L}$. The low iron concentrations at wells 43 and 104 may be because of recent recharge to the aquifer.

Other constituents of interest in the study area are the nutrients nitrogen and phosphorus. Some small amounts of phosphorus are found in ground water because of the dissolution of phosphate minerals, but nitrogen is nearly always found in water as the result of biological activity (Hem, 1970, p. 180-187). Nitrogen and phosphorus compounds in ground water generally are the result of human activities, such as the application of fertilizers or because of the presence of human or animal waste. In surface water, high nutrient concentrations are detrimental because they encourage the rapid growth of algae which deplete the water of the oxygen necessary for fish to survive. In ground water used for potable water supply, nitrate concentrations greater than $10 \mathrm{mg} / \mathrm{L}$ can cause methemoglobinemia, a disease that can be fatal to infants under the age of 1 year (U.S. Environmental Protection Agency, 1989). Because the presence of nutrients in ground water generally indicates influence of human activity, their presence can also indicate other potential problems, such as contamination by bacteria and viruses.

In general, nutrient concentrations in the upper zone are higher in the western part of the county (the agricultural area) than in the eastern part. Nutrient concentrations in water from wells tapping the upper permeable zone are given in table 9. The highest concentration of total ammonia $(1.20 \mathrm{mg} / \mathrm{L}$ as $\mathrm{N})$ was at well 228, in eastern Volusia County; the lowest concentrations $(0.02 \mathrm{mg} / \mathrm{L})$ were at wells 118 and 122 . Well 118 , a backyard irrigation well, had a relatively high concentration of nitrate-plus-nitrite of $5.4 \mathrm{mg} / \mathrm{L}$ (as N). High nitrate-plus-nitrite concentrations also were detected in samples from well $105(18 \mathrm{mg} / \mathrm{L})$, in an agricultural area, and well $52(14 \mathrm{mg} / \mathrm{L})$, which is a backyard irrigation well. Ten wells had nitrate-plus-nitrite concentrations of less than $0.02 \mathrm{mg} / \mathrm{L}$ as $\mathrm{N}$, the detection limit for the laboratory method used. Well 122 , a test well near De Leon Springs, had the highest total phosphorous concentration ( $7 \mathrm{mg} / \mathrm{L}$ as $\mathrm{P}$ ) of all the upper zone wells. The minimum total phosphorous concentration $(0.04 \mathrm{mg} / \mathrm{L})$ was at well 129 , a test well along a highway right-of-way near Daytona Beach. The maximum orthophosphate concentration $(1.3 \mathrm{mg} / \mathrm{L}$ as $\mathrm{P})$ was in a backyard irrigation well (well 86) and the minimum concentration (less than $0.01 \mathrm{mg} / \mathrm{L}$ ), was at well 52 . 


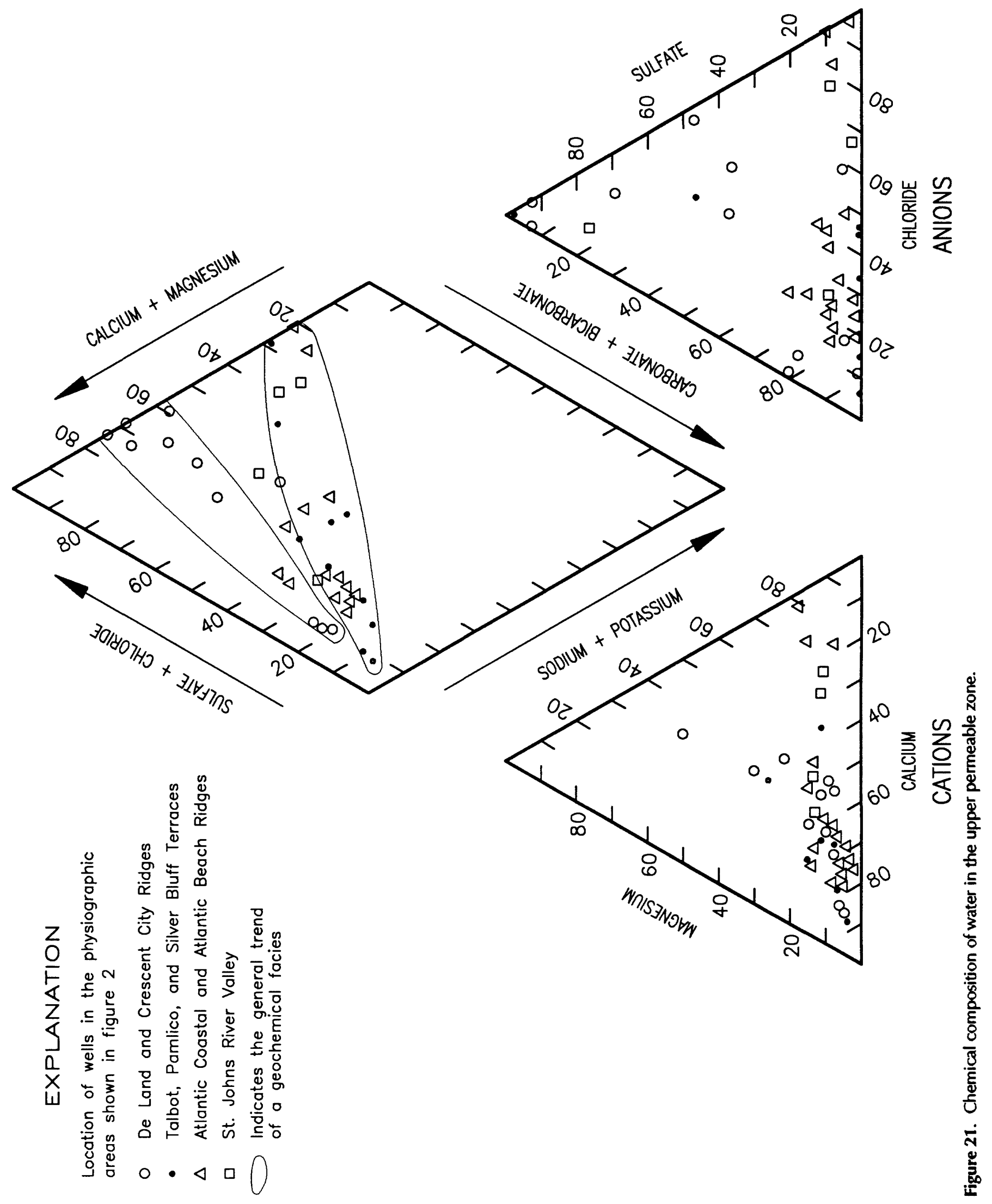




\section{Lower Permeable Zone}

Thirteen wells tapping the lower permeable zone of the surficial aquifer system were also sampled and analyzed in 1987. Results of these analyses are given in tables 10 and 11. The chloride concentration ranged from a minimum of $5.7 \mathrm{mg} / \mathrm{L}$ at well 98 to a maximum of $340 \mathrm{mg} / \mathrm{L}$ at well 132 , in an area of artesian flow from the underlying Upper Floridan aquifer. The median chloride concentration for all samples was $10 \mathrm{mg} / \mathrm{L}$. The median specific conductance for all samples was $300 \mu \mathrm{S} / \mathrm{cm}$. The maximum was $1,400 \mu \mathrm{S} / \mathrm{cm}$ at well 132 and the minimum was $200 \mu \mathrm{S} / \mathrm{cm}$ at well 98. Hardness ranged from $85 \mathrm{mg} / \mathrm{L}\left(\right.$ as $\left.\mathrm{CaCO}_{3}\right)$ at well 98 , to 360 at well 132 , with a median value of $130 \mathrm{mg} / \mathrm{L}$.

A trilinear diagram showing ionic compositions for water samples from wells in the lower permeable zone is shown in figure 22 . Most of the wells yield calcium bicarbonate type water. Data are insufficient to determine if both calcium magnesium sulfate type and sodium chloride type waters exist in the zone.

The median total iron concentrations for water from the lower zone was $1,300 \mu \mathrm{g} / \mathrm{L}$ and the median dissolved iron concentration was $130 \mu \mathrm{g} / \mathrm{L}$. Total iron concentrations in water from the lower zone ranged from a maximum of $82,000 \mu \mathrm{g} / \mathrm{L}$ at well 166 to a minimum of $130 \mu \mathrm{g} / \mathrm{L}$ at well 231. Dissolved iron concentrations ranged from $640 \mu \mathrm{g} / \mathrm{L}$ at well 67 to $20 \mu \mathrm{g} / \mathrm{L}$ at well 132. As mentioned previously, some of the total iron may be contributed by particles spalled from the well casing or from suspended sediments.

Nutrient concentrations for wells tapping the lower zone are given in table 11. Ammonia-plus-total-organic nitrogen ranged from less than $0.2 \mathrm{mg} / \mathrm{L}$ as $\mathrm{N}$ at well 98 to $2.7 \mathrm{mg} / \mathrm{L}$ at well 67 , located in De Land. Other wells that yielded water with ammonia-plus-organic nitrogen concentrations greater than $2.0 \mathrm{mg} / \mathrm{L}$ were wells 106 and 166 , both in agricultural areas. At well 106 the ammoniaplus-organic-nitrogen concentration was $2.2 \mathrm{mg} / \mathrm{L}$, whereas the nitrate-plus-nitrite nitrogen concentration was less than $0.02 \mathrm{mg} / \mathrm{L}$; at well 105 , a water-table well at the same location, ammonia-plus-organic nitrogen concentration was $0.3 \mathrm{mg} / \mathrm{L}$ whereas the nitrate-plus-nitrite nitrogen concentration was $18 \mathrm{mg} / \mathrm{L}$. The highest nitrate-plus-nitrite concentration in water from an intermediate aquifer well was $0.430 \mathrm{mg} / \mathrm{L}$ as $\mathrm{N}$ at well 231, located in Bulow Creek State Park in the eastern part of the county.

The highest total phosphorus concentration was $11 \mathrm{mg} / \mathrm{L}$ at well 67 (which also had the highest concentration of ammonia-plus-organic nitrogen). Total phosphorus at well 66, an upper zone well at the same location, was only $0.06 \mathrm{mg} / \mathrm{L}$. Total phosphorus concentrations greater than $5 \mathrm{mg} / \mathrm{L}$ were also found at well 166 (in an agricultural area), well 196 (in a pasture), and well 123 (in a woodland area). Well 122, an upper zone well at the same location as well 123, also had the highest total phosphorus concentration of the upper zone wells. These concentrations were probably affected by septic tank effluent. Although in some cases nutrient concentrations appear to be related to use of fertilizers or other agricultural activities, other nutrient data are more difficult to explain, such as the nutrient concentrations at wells 67,166 , and 231 . The reconnaissance nature of the water-quality sampling during this study did not yield sufficient data to show correlations between land use and water quality. Also, in some areas, phosphate concentrations in water in the lower zone may be related to phosphate minerals in the aquifer.

\section{Summary of Water Quality from Both Zones}

A summary of the range of properties and constituents in waters from the two zones is given in table 12 . The median concentrations for some constituents are lower in the lower permeable zone than for wells tapping the upper permeable zone; however, statistical comparisons between the water quality of the upper and lower zones cannot be made with the data available because water quality depends not only on aquifer zone, but also on physiographic location of the well. Without data from both zones at numerous sites in each physiographic area, meaningful comparisons cannot be made.

Figure 23 shows major-ion concentrations of water from selected wells and the mean concentrations for all wells sampled in each zone. The wells were selected to show the range in concentration of constituents in water from each zone. Wells 34 and 228 were deleted from the calculations of the means for upper zone wells because of their very high dissolved solids concentrations. In both zones, the water generally has a high chloride concentration in areas where the underlying Floridan aquifer system contains salty water (Rutledge, 1985a, fig. 30). The median concentration of dissolved iron was $230 \mu \mathrm{g} / \mathrm{L}$ for the upper zone and $130 \mu \mathrm{g} / \mathrm{L}$ for the lower zone.

\section{SUMMARY AND CONCLUSIONS}

In Volusia County, the Miocene-to-Holocene age sediments that overlie the Floridan aquifer system constitute the surficial aquifer system. The sediments consist of sand, silt, clay, and shell that collectively range in thickness from about 40 to more than 100 feet in some areas of the western part of the county. In many areas of the county, the surficial aquifer system can be subdivided into an upper and a lower permeable zone which are separated by 5 to 10 feet of clay and silty material. Although the clay or silt layers were found at numerous sites, they are not believed to be areally continuous.

About 4,500 wells are completed into the surficial aquifer system in Volusia County, of which more than 3,200 are used for irrigation. About 800 wells that tap the surficial aquifer system are used for domestic supply. Estimated total water use from the surficial aquifer system in 1987 is $4.2 \mathrm{Mgal} / \mathrm{d}$. 


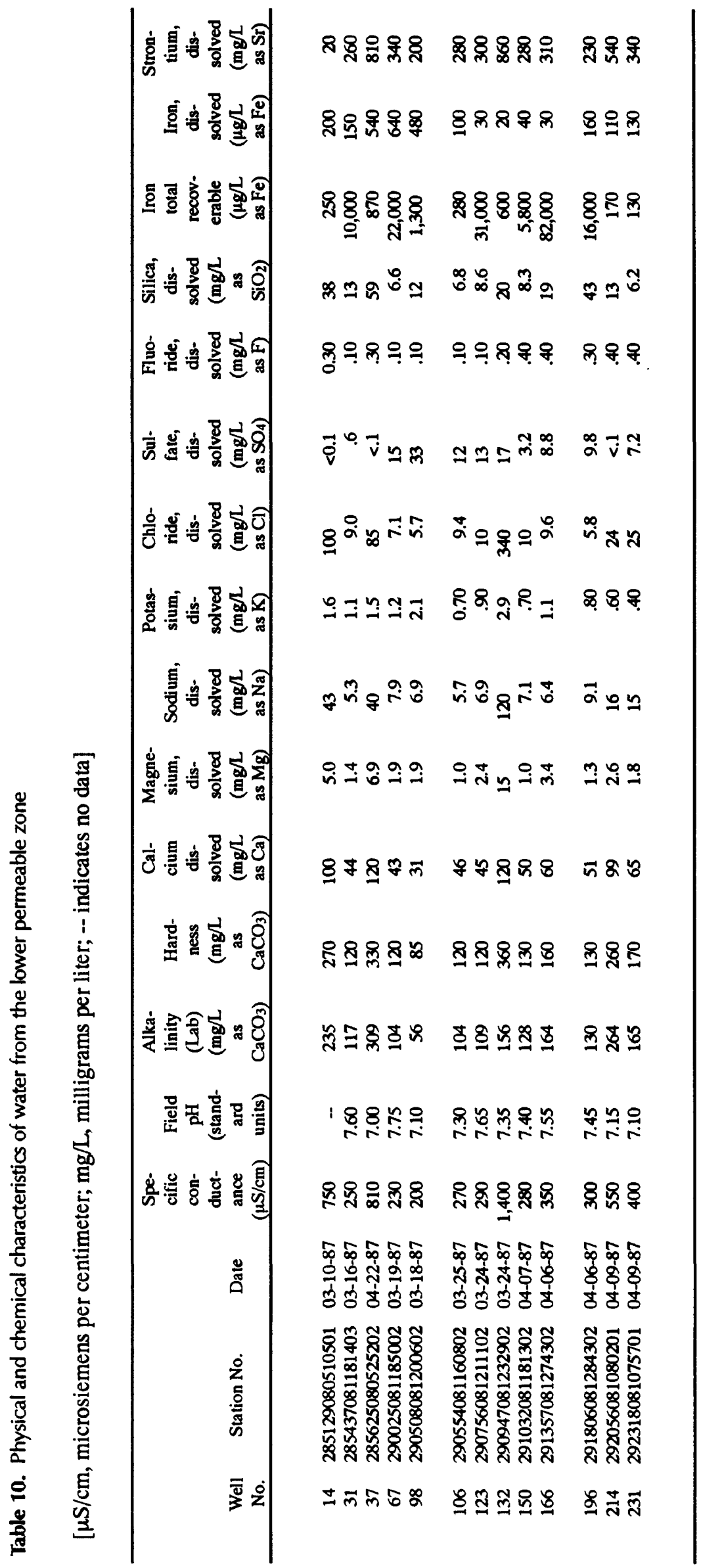


Table 11. Nutrient concentrations in water from the lower permeable zone

\begin{tabular}{|c|c|c|c|c|c|c|c|c|}
\hline $\begin{array}{l}\text { Well } \\
\text { No. }\end{array}$ & Station No. & Date & $\begin{array}{l}\text { Nitro- } \\
\text { gen, } \\
\text { ammonia, } \\
\text { total } \\
\text { (mg/L } \\
\text { as N) }\end{array}$ & $\begin{array}{l}\text { Nitro- } \\
\text { gen, } \\
\text { nitrite, } \\
\text { total } \\
\text { (mg/L } \\
\text { as N) }\end{array}$ & $\begin{array}{l}\text { Nitro- } \\
\text { gen, am- } \\
\text { monia plus } \\
\text { organic } \\
\text { total } \\
\text { (mg/L } \\
\text { as N) }\end{array}$ & $\begin{array}{c}\text { Nitro- } \\
\text { gen, } \mathrm{NO}_{2} \\
\text { plus } \\
\mathrm{NO}_{3} \\
\text { total } \\
\text { (mg/L } \\
\text { as } \mathrm{N} \text { ) }\end{array}$ & $\begin{array}{l}\text { Phos- } \\
\text { phorus, } \\
\text { total } \\
\text { (mg/L } \\
\text { as P) }\end{array}$ & $\begin{array}{l}\text { Phos- } \\
\text { phorus, } \\
\text { ortho, } \\
\text { total } \\
\text { (mg/L } \\
\text { as P) }\end{array}$ \\
\hline 31 & 285437081181403 & $03-16-87$ & .040 & $<.010$ & .93 & .030 & 4.60 & .070 \\
\hline 37 & 285625080525202 & $04-22-87$ & .820 & $<.010$ & 1.0 & $<.020$ & .200 & .070 \\
\hline 67 & 290025081185002 & $03-19-87$ & .040 & $<.010$ & 2.7 & .080 & 11.0 & .090 \\
\hline 98 & 290508081200602 & $03-18-87$ & .060 & $<.010$ & $<.20$ & $<.020$ & .500 & .160 \\
\hline 123 & 290756081211102 & $03-24-87$ & .090 & $<.010$ & 1.2 & $<.020$ & 6.20 & .040 \\
\hline 132 & 290947081232902 & $03-24-87$ & .420 & $<.010$ & .50 & $<.020$ & .140 & .070 \\
\hline 150 & 291032081181302 & $04-07-87$ & .080 & .020 & .50 & .030 & 2.30 & .450 \\
\hline 166 & 291357081274302 & 04-06-87 & .060 & $<.010$ & 2.0 & $<.020$ & 7.80 & .100 \\
\hline 196 & 291806081284302 & $04-06-87$ & .200 & .030 & 1.3 & .070 & 5.60 & .820 \\
\hline 214 & 292056081080201 & $04-09-87$ & .130 & .010 & .22 & .020 & .310 & .280 \\
\hline 231 & 292318081075701 & $04-09-87$ & .080 & $<.010$ & .32 & .430 & .150 & .120 \\
\hline
\end{tabular}

During the study, water levels were measured periodically in about 90 wells and continuously in two wells tapping the surficial aquifer system. The depth to water below land surface varies with the topography and ranges from less than 10 feet below to 30 feet or more below land surface. In 1986, water levels in wells tapping the upper zone generally were 3 to 6 feet higher in the fall, at the end of the wet season, than in the spring. The maximum waterlevel fluctuation measured between wet and dry seasons was 5 feet. Water levels in several wells fluctuated less than 1 foot. Water levels in wells tapping the lower zone generally fluctuated less than 2 feet, except those that were affected by pumping from the Upper Floridan aquifer for freeze protection during February 1987.

The highest recharge rates to the surficial aquifer system (and thus, to the Upper Floridan aquifer) are found along the De Land Ridge and the western part of the Talbot Terrace. The recharge rate on the ridge areas probably ranges from about 9 to $18 \mathrm{in} / \mathrm{yr}$, whereas in nonridge areas the rate ranges from about 0 to $8 \mathrm{in} / \mathrm{yr}$. Recharge rates calculated by summing the rises in the hydrographs of three wells are higher than rates estimated from water budgets, partly because some of the recharge measured in the hydrograph method comprises ground-water outflow which was assumed to be negligible in water-budget calculations.

Laboratory hydraulic conductivity values for core samples of clay collected in Volusia County ranged from $7.6 \times 10^{-5}$ to $3.4 \times 10^{-1} \mathrm{ft} / \mathrm{d}$ with a median of $1.0 \times 10^{-2} \mathrm{ft} / \mathrm{d}$. Field hydraulic conductivities determined by slug tests ranged from $3.0 \times 10^{-2}$ to $12.8 \mathrm{ft} / \mathrm{d}$ with a median of $2.9 \times 10^{-1} \mathrm{ft} / \mathrm{d}$.

The transmissivity of the lower permeable zone of the surficial aquifer system in Oak Hill (southeastern Volusia County) determined from an aquifer test, was $1,200 \mathrm{ft}^{2} / \mathrm{d}$. In the Oak Hill area, the rate at which water can be produced from the lower zone is limited by the possibility of upconing saltwater from the underlying Upper Floridan aquifer rather than by the hydraulic properties of the aquifer.

Water samples from 39 wells tapping the upper zone and 13 wells tapping the lower zone were analyzed for major constituents, trace elements, and nutrients. Chloride concentrations for the upper permeable zone ranged from $1.2 \mathrm{mg} / \mathrm{L}$ to $15,000 \mathrm{mg} / \mathrm{L}$; for the lower permeable zone the range was $5.7 \mathrm{mg} / \mathrm{L}$ to $340 \mathrm{mg} / \mathrm{L}$. In both zones nutrient concentrations at some sites were higher than would be expected for natural ground water, indicating some effect from surface water or human activity. 


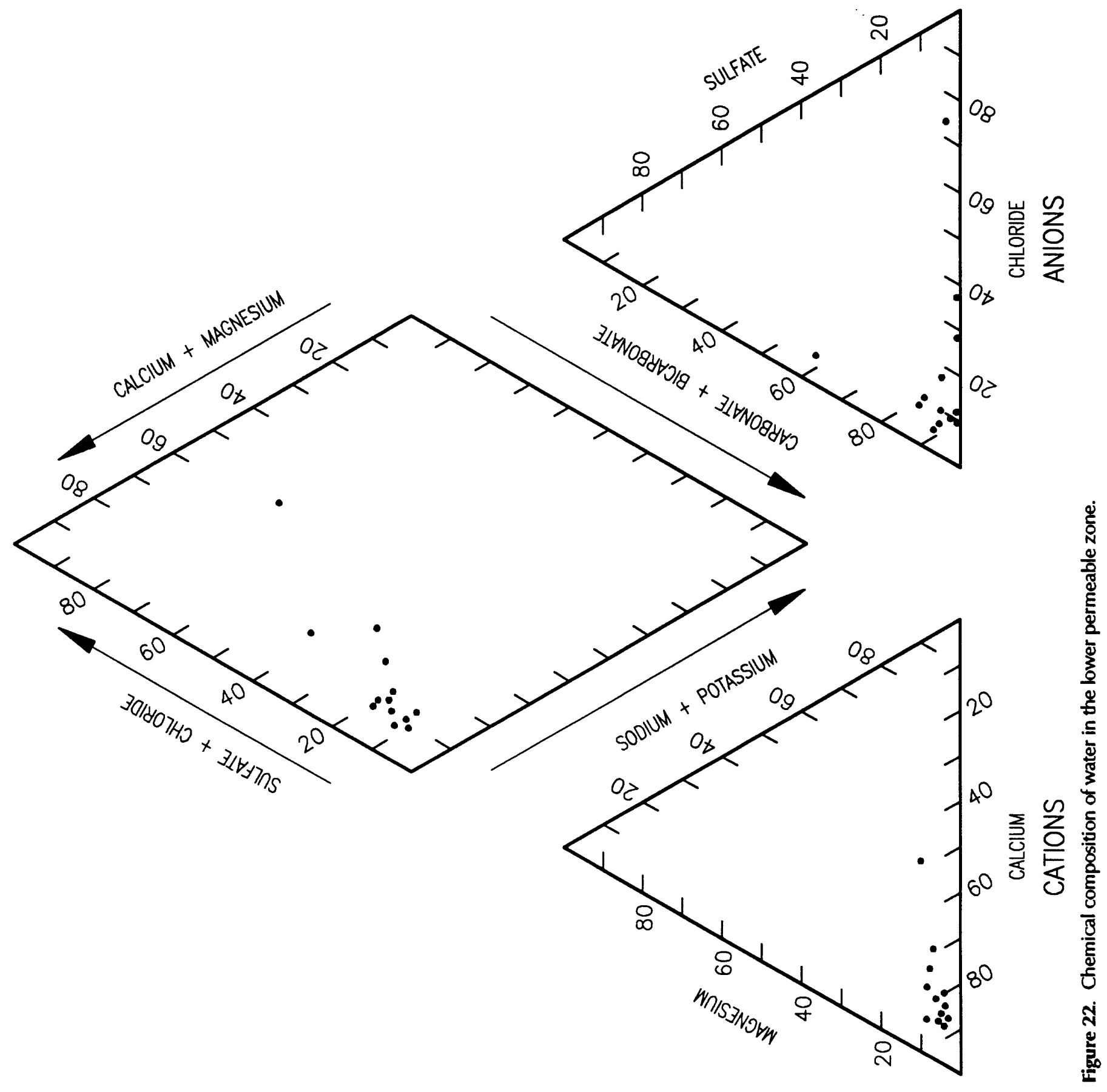


Table 12. Statistical summary for physical and chemical characteristics of water from the upper and lower permeable zones of the surficial aquifer system, Volusia County

[Aquifer zone: U, upper zone; L, lower zone]

\begin{tabular}{|c|c|c|c|c|c|}
\hline $\begin{array}{l}\text { Characteristic } \\
\text { or constituent }\end{array}$ & $\begin{array}{c}\text { Aquifer } \\
\text { zone }\end{array}$ & $\begin{array}{r}\text { Number } \\
\text { of samples }\end{array}$ & Minimum & Median & Maximum \\
\hline Specific conductance $(\mu \mathrm{S} / \mathrm{cm})$ & $\begin{array}{l}\mathrm{U} \\
\mathrm{L}\end{array}$ & $\begin{array}{l}46 \\
13\end{array}$ & $\begin{array}{r}35 \\
200\end{array}$ & $\begin{array}{l}405 \\
300\end{array}$ & $\begin{array}{r}41,800 \\
1,400\end{array}$ \\
\hline Hardness (mg/L as $\mathrm{CaCO}_{3}$ ) & $\begin{array}{l}\mathrm{U} \\
\mathrm{L}\end{array}$ & $\begin{array}{l}40 \\
13\end{array}$ & $\begin{array}{r}5 \\
85\end{array}$ & $\begin{array}{l}140 \\
130\end{array}$ & $\begin{array}{r}5,000 \\
360\end{array}$ \\
\hline $\begin{array}{l}\text { Noncarbonate hardness } \\
\left(\mathrm{mg} / \mathrm{L} \text { as } \mathrm{CaCO}_{3}\right)\end{array}$ & $\begin{array}{l}\text { U } \\
\text { L }\end{array}$ & $\begin{array}{l}40 \\
13\end{array}$ & $\begin{array}{l}0 \\
0\end{array}$ & $\begin{array}{l}15 \\
12\end{array}$ & $\begin{array}{r}2,100 \\
210\end{array}$ \\
\hline Alkalinity (mg/ as $\mathrm{CaCO}_{3}$ ) & $\begin{array}{l}\mathbf{U} \\
\mathrm{L}\end{array}$ & $\begin{array}{l}39 \\
13\end{array}$ & $\begin{array}{l}1.8 \\
56\end{array}$ & $\begin{array}{l}132 \\
130\end{array}$ & $\begin{array}{l}341 \\
309\end{array}$ \\
\hline Calcium (mg/L as $\mathrm{Ca}$ ) & $\begin{array}{l}\mathrm{U} \\
\mathrm{L}\end{array}$ & $\begin{array}{l}41 \\
13\end{array}$ & 31.5 & $\begin{array}{l}52 \\
51\end{array}$ & $\begin{array}{l}400 \\
120\end{array}$ \\
\hline Magnesium (mg/L as Mg) & $\begin{array}{l}\mathbf{U} \\
\mathrm{L}\end{array}$ & $\begin{array}{l}41 \\
13\end{array}$ & $\begin{array}{r}.4 \\
1.0\end{array}$ & $\begin{array}{l}2.5 \\
1.9\end{array}$ & $\begin{array}{r}1,000 \\
15\end{array}$ \\
\hline Sodium (mg/L as $\mathrm{Na}$ ) & $\begin{array}{l}\text { U } \\
\mathrm{L}\end{array}$ & $\begin{array}{l}41 \\
13\end{array}$ & $\begin{array}{l}2.2 \\
5.3\end{array}$ & $\begin{array}{l}16 \\
7.9\end{array}$ & $\begin{array}{r}8,800 \\
120\end{array}$ \\
\hline Potassium (mg/L as $\mathrm{K}$ ) & $\begin{array}{l}\mathbf{U} \\
\mathrm{L}\end{array}$ & $\begin{array}{l}41 \\
13\end{array}$ & $\begin{array}{l}.2 \\
.4\end{array}$ & $\begin{array}{l}1.8 \\
1.1\end{array}$ & $\begin{array}{l}310 \\
2.9\end{array}$ \\
\hline Chloride (mg/L as $\mathrm{Cl}$ ) & $\begin{array}{l}\mathbf{U} \\
\mathrm{L}\end{array}$ & $\begin{array}{l}57 \\
13\end{array}$ & $\begin{array}{l}1.2 \\
5.7\end{array}$ & $\begin{array}{l}36 \\
10\end{array}$ & $\begin{array}{r}15,000 \\
340\end{array}$ \\
\hline Sulfate (mg/L as SO) & $\begin{array}{l}\text { U } \\
\mathrm{L}\end{array}$ & $\begin{array}{l}41 \\
13\end{array}$ & $\begin{array}{l}0 \\
.1\end{array}$ & $\begin{array}{c}10 \\
8.8\end{array}$ & $\begin{array}{r}2,100 \\
33\end{array}$ \\
\hline Fluoride ( $\mathrm{mg} / \mathrm{L}$ as $\mathrm{F})$ & $\begin{array}{l}\text { U } \\
\text { L }\end{array}$ & $\begin{array}{l}41 \\
13\end{array}$ & $\begin{array}{l}.10 \\
.10\end{array}$ & $\begin{array}{l}.30 \\
.30\end{array}$ & $\begin{array}{r}1.20 \\
.40\end{array}$ \\
\hline Silica (mg/L as SiO) & $\begin{array}{l}\mathrm{U} \\
\mathrm{L}\end{array}$ & $\begin{array}{l}41 \\
13\end{array}$ & $\begin{array}{l}1.5 \\
6.2\end{array}$ & $\begin{array}{l}7.5 \\
13\end{array}$ & $\begin{array}{l}25 \\
59\end{array}$ \\
\hline Strontium ( $\mu \mathrm{g} / \mathrm{L}$ as $\mathrm{Sr}$ ) & $\begin{array}{l}\mathrm{U} \\
\mathrm{L}\end{array}$ & $\begin{array}{l}40 \\
13\end{array}$ & $\begin{array}{l}30 \\
20\end{array}$ & $\begin{array}{l}295 \\
300\end{array}$ & $\begin{array}{r}6,000 \\
860\end{array}$ \\
\hline Iron, total ( $\mu \mathrm{g} / \mathrm{L}$ as $\mathrm{Fe})$ & $\begin{array}{l}\mathrm{U} \\
\mathrm{L}\end{array}$ & $\begin{array}{l}38 \\
13\end{array}$ & $\begin{array}{r}30 \\
130\end{array}$ & $\begin{array}{r}900 \\
1,300\end{array}$ & $\begin{array}{l}68,000 \\
82,000\end{array}$ \\
\hline Iron, dissolved ( $\mu \mathrm{g} / \mathrm{L}$ as $\mathrm{Fe})$ & $\begin{array}{l}\mathrm{U} \\
\mathrm{L}\end{array}$ & $\begin{array}{l}39 \\
13\end{array}$ & 20 & $\begin{array}{l}230 \\
130\end{array}$ & $\begin{array}{r}65,000 \\
640\end{array}$ \\
\hline Ammonia (mg/Las $N$ ) & $\begin{array}{l}\mathrm{U} \\
\mathrm{L}\end{array}$ & $\begin{array}{l}40 \\
13\end{array}$ & $\begin{array}{l}.02 \\
.04\end{array}$ & $\begin{array}{l}.07 \\
.09\end{array}$ & $\begin{array}{c}1.2 \\
.82\end{array}$ \\
\hline Nitrite (mg/L as $N$ ) & $\begin{array}{l}\mathrm{U} \\
\mathrm{L}\end{array}$ & $\begin{array}{l}40 \\
13\end{array}$ & $\begin{array}{l}.01 \\
.01\end{array}$ & $\begin{array}{l}.01 \\
.01\end{array}$ & $\begin{array}{l}.16 \\
.03\end{array}$ \\
\hline $\begin{array}{l}\text { Ammonia plus organic nitrogen } \\
(\mathrm{mg} / \mathrm{L} \text { as } \mathrm{N})\end{array}$ & $\begin{array}{l}\mathrm{U} \\
\mathrm{L}\end{array}$ & $\begin{array}{l}40 \\
13\end{array}$ & $\begin{array}{l}.20 \\
.20\end{array}$ & $\begin{array}{l}.38 \\
.93\end{array}$ & $\begin{array}{l}3.0 \\
2.7\end{array}$ \\
\hline $\begin{array}{l}\text { Nitrate plus nitrite } \\
\text { (mg/L as } N \text { ) }\end{array}$ & $\begin{array}{l}\mathrm{U} \\
\mathrm{L}\end{array}$ & $\begin{array}{l}40 \\
13\end{array}$ & $\begin{array}{l}.02 \\
.02\end{array}$ & $\begin{array}{l}.05 \\
.02\end{array}$ & ${ }_{.43}^{18}$ \\
\hline Phosphorus (mg/L as $\mathrm{P}$ ) & $\begin{array}{l}\mathrm{U} \\
\mathrm{L}\end{array}$ & $\begin{array}{l}40 \\
13\end{array}$ & $\begin{array}{l}.04 \\
.14\end{array}$ & $\begin{array}{l}.32 \\
.50\end{array}$ & $\begin{array}{r}7 \\
11\end{array}$ \\
\hline $\begin{array}{l}\text { Orthophosphate, total } \\
\text { (mg/L as } P \text { ) }\end{array}$ & $\begin{array}{l}\mathrm{U} \\
\mathrm{L}\end{array}$ & $\begin{array}{l}40 \\
13\end{array}$ & $\begin{array}{l}.01 \\
.04\end{array}$ & $\begin{array}{l}.09 \\
.12\end{array}$ & $\begin{array}{l}1.3 \\
.82\end{array}$ \\
\hline
\end{tabular}



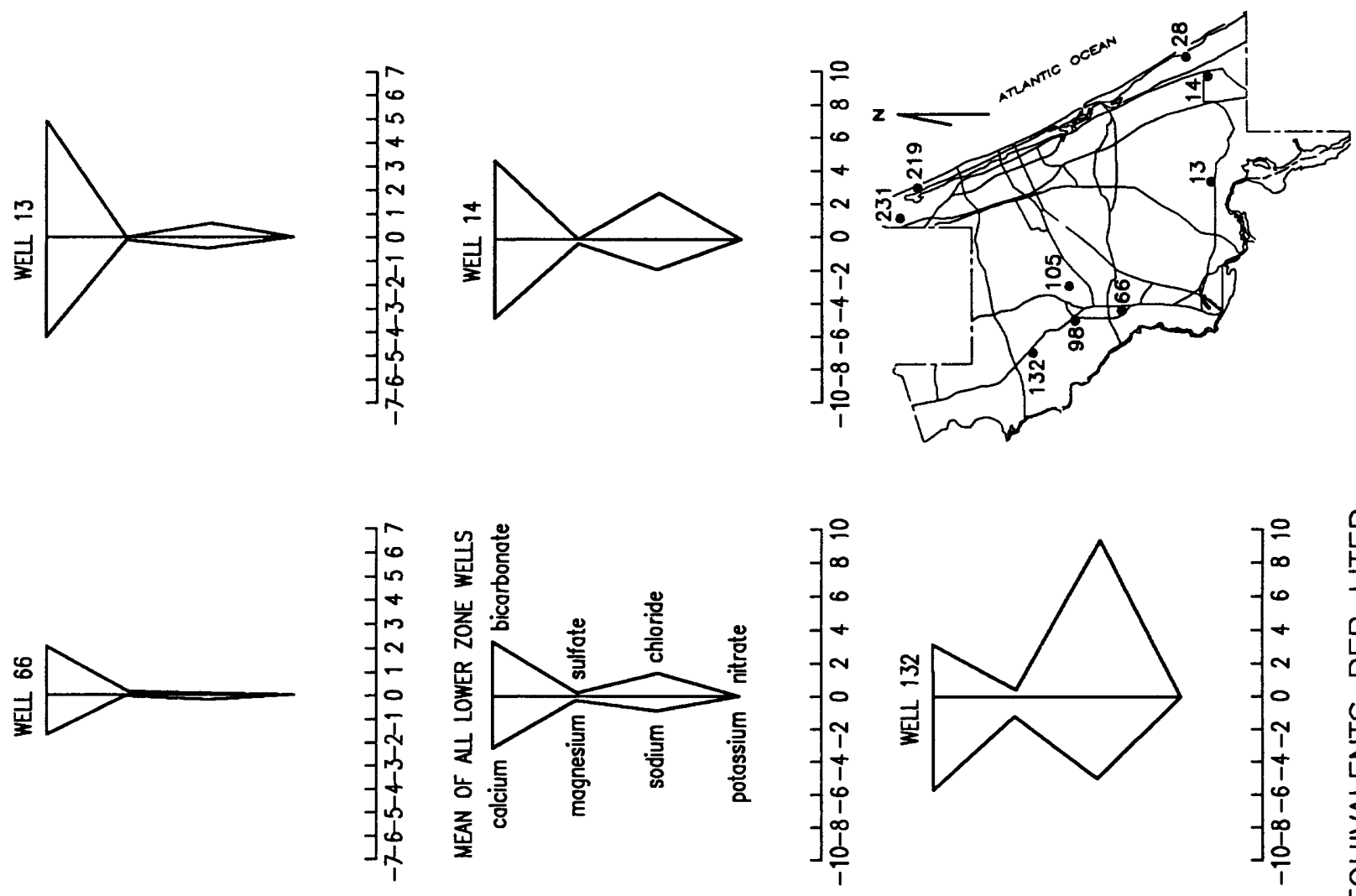

0
$-\infty$
-0
-0
-1
-0
-1
-1
$\vdots$
0
0
0
0
0
0
1

岂
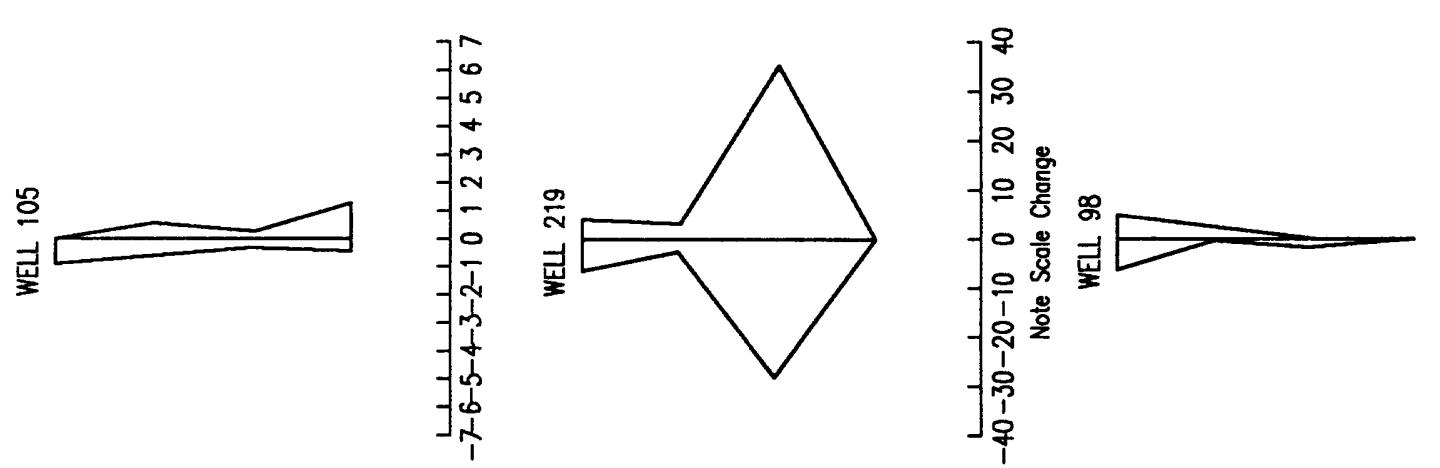

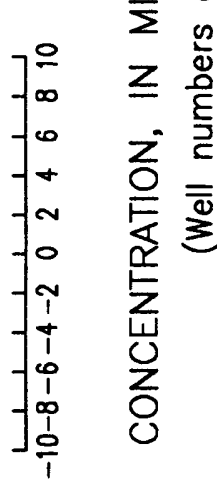
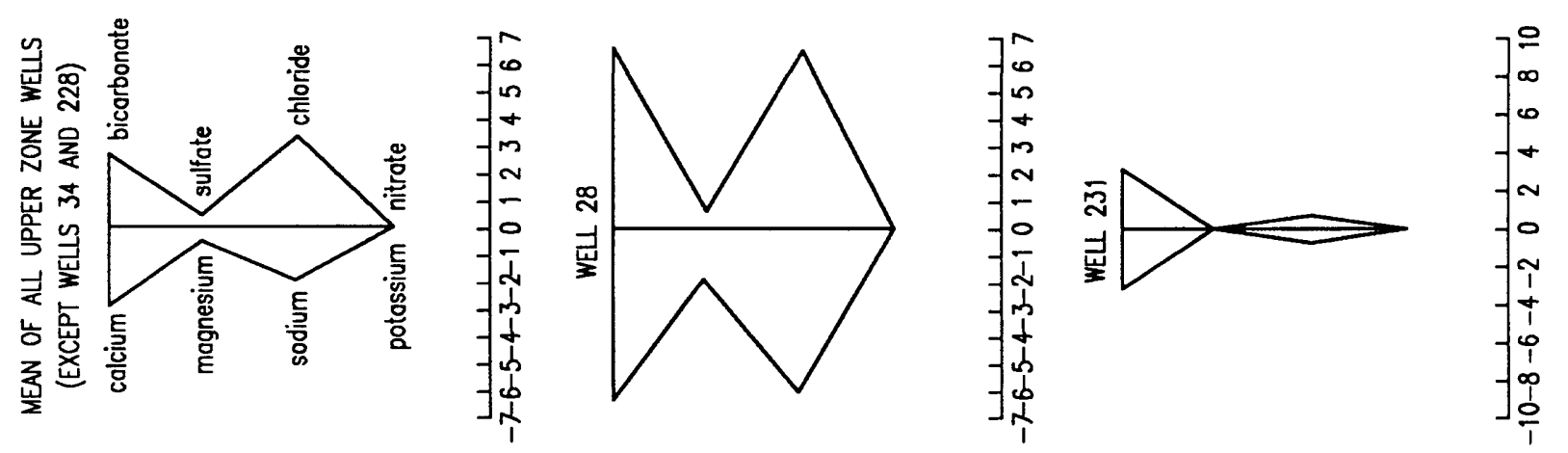


\section{SELECTED REFERENCES}

Bermes, B.J., 1958, Interim report on the ground-water resources of Flagler County, Florida: Florida Geological Survey Information Circular 13, 32 p.

Bouwer, Herman, 1978, Ground water hydrology: New York, McGraw-Hill, 480 p.

Bouwer, Herman, and Rice, R.C., 1976, A slug test for determining hydraulic conductivity of unconfined aquifers with completely or partially penetrating wells: Water Resources Research, v. 12, no. 3, p. 423-428.

Brooks, H.K., 1981, Geologic map of Florida: Gainesville, Florida Cooperative Extension Service, Institute of Food and Agricultural Sciences, University of Florida, 1 sheet.

Bush, P.W., 1978, Hydrologic evaluation of part of central Volusia County, Florida: U.S. Geological Survey Water-Resources Investigations $78-89,50 \mathrm{p}$.

Causey, L.V., and Leve, G.W., 1976, Thickness of the potable-water zone in the Floridan aquifer: U.S. Geological Survey and Florida Department of Environmental Regulation, Tallahassee, Fla., 1 sheet.

Cooke, C.W., 1945, Geology of Florida: Florida Geological Survey Bulletin 29, 339 p.

Ferris, J.G. and Knowles, D.B., 1963, Methods of determining permeability, transmissibility and drawdown: U.S. Geological Survey Water-Supply Paper 1536-I, p. 299-304.

Ferris, J.G., Knowles, D.B., Brown, R.H., and Stallman, R.W., 1962, Theory of aquifer tests: U.S. Geological Survey WaterSupply Paper $1536-\mathrm{E}, 174 \mathrm{p}$.

Gomberg, D.N., 1980, Available groundwater at National Gardens Trust, Volusia County, Florida: Prepared for Bellemead Development Corp., appendices A-C, 63 p.

.... 1981, Water resources and available ground water at Halifax Plantation, Volusia and Flagler Counties, Florida: appendices A-E, 98 p.

-.-- 1985a, Water level data for National Gardens, 1980-1985: $18 \mathrm{p}$.

-...- 1985b, Hydrogeology and water supply sources at National Gardens, Volusia County, Florida, 53 p.

Healy, H.G., 1975, Terraces and shorelines of Florida: Forida Geological Survey Map Series 71, 1 sheet.

Hem, J.D., 1970, Study and interpretation of the chemical characteristics of natural water: U.S. Geological Survey Water-Supply Paper 1473, 363 p.

Irwin, G.A., and Kirkland, R.T., 1980, Chemical and physical characteristics of precipitation at selected sites in Florida: U.S. Geological Survey Water-Resources Investigations Report 80-81, 70 p.

Jacob, C.E., 1946, Radial flow in a leaky artesian aquifer: American Geophysical Union Transactions, v. 27, no. 2, p. 198-205; duplicated, as U.S. Geological Survey Ground Water Note 13, 1953.

Kimrey, J.O., 1990, Potential for ground-water development in central Volusia County, Florida: U.S. Geological Survey Water Resources Investigations Report 90-4010, 31 p.

Knochenmus, D.D., 1968, Surface drainage characteristics in Volusia County, Florida: Florida Division of Geology Map Series 30,1 sheet.
Knochenmus, D.D., and Beard, M.E., 1971, Evaluation of the quantity and quality of the water resources of Volusia County, Florida: Florida Bureau of Geology Report of Investigations $57,59 \mathrm{p}$.

Laughlin, C.P., and Collins, D.C., 1969, Second annual report on the program of water data collection, Volusia County, Florida: U.S. Geological Survey open-file report, Ocala, Fla., 48 p.

Lichtler, W.F., 1972, Appraisal of water resources in the east central Florida region: Florida Bureau of Geology Report of Investigations 61, $52 \mathrm{p}$.

MacNeil, F.S., 1950, Pleistocene shorelines in Florida and Georgia: U.S. Geological Survey Professional Paper 221-F, p. 95-107.

Marella, R.L., 1986, Annual water use survey, 1985: St. Johns River Water Management District Technical Publication SJ 86-5, Palatka, Florida, 117 p.

McGurk, Brian, Bond, Paulette, and Mehan, Doug, 1989, Hydrogeologic and lithologic characteristics of the surficial sediments in Volusia County, Florida: St. Johns River Water Management District Technical Publication SJ 89-7, p. 38 and appendices $\mathrm{A}-\mathrm{H}$.

Miller, J.A., 1986, Hydrogeologic framework of the Floridan aquifer system in Florida and in parts of Georgia, Alabama, and South Carolina: U.S. Geological Survey Professional Paper 1403-B, 91 p.

Munch, D.A., 1979, Test drilling report of Northwest Volusia County: St. Johns River Water Management District Technical Memorandum 1, $18 \mathrm{p}$.

National Oceanic and Atmospheric Administration, Climatological data, annual summary for Florida, v. 85, no. 13.

-.-- Climatological data, annual summary for Florida, v. 86, no. 13.

Phelps, G.G., 1985, Recharge and discharge areas of the Floridan aquifer in the St. Johns River Water Management District and vicinity, Florida: U.S. Geological Survey Water-Resources Investigations Report 82-4058, 1 sheet.

Puri, H.S., 1957, Stratigraphy and zonation of the Ocala Group: Florida Bureau of Geology Bulletin 38, 248 p.

Rasmussen, W.C., and Andreasen, G.E., 1959, Hydrologic budget of the Beaverdam Creek basin, Maryland: U.S. Geological Survey Water-Supply Paper 1472, 106 p.

Ross, F.W., and Munch, D.A., 1980, Hydrologic investigation of the potentiometric high centered about the Crescent City Ridge, Putnam County, Florida: St. Johns River Water Management District Technical Report 5, appendix and 75 p.

Rutledge, A.T., 1982, Hydrology of the Floridan aquifer in northwest Volusia County, Florida: U.S. Geological Survey Water-Resources Investigations Open-File Report 82-108, $116 \mathrm{p}$, and 1 sheet.

-... 1985a, Ground-water hydrology of Volusia County, Florida, with emphasis on occurrence and movement of brackish water: U.S. Geological Survey Water-Resources Investigations Report 84-4206, 84 p.

.... 1985b, Use of double-mass curves to determine drawdown in a long-term aquifer test in north-central Volusia County, Florida: U.S. Geological Survey Water-Resources Investigations Report 84-4309, 29 p.

Schiner, G.R., 1986, Potentiometric surface of the Upper Floridan aquifer in the St. Johns River Water Management District and vicinity, Florida, May 1986: U.S. Geological Survey OpenFile Report 86-408, 1 sheet. 
Shampine, WJ., 1975, Chloride concentration in water from the upper part of the Floridan aquifer in Florida: Florida Department of Natural Resources Map Series 12, 1 sheet.

Simonds, E.P., Jr., McPherson, B.F., and Bush, P.W., 1980, Shallow ground-water conditions and vegetation classification, central Volusia County, Florida: U.S. Geological Survey Water-Resources Investigations Open-File Report 80-752, 1 sheet.

Skougstad, M.W., Fishman, M.J., Friedman, L.C., Erdmann, D.E., and Duncan, S.S., eds., 1979, Methods for determination of inorganic substances in water and fluvial sediments: U.S. Geological Survey Techniques of Water-Resources Investigations, Book 5, Chap. A1, 626 p.

Snell, L.J., and Anderson, Warren, 1970, Water resources of northeast Florida: Florida Bureau of Geology Report of Investigation 54, $77 \mathrm{p}$.

Spechler, R.M., 1987, Potentiometric surface of the Upper Floridan aquifer in the St. Johns River Water Management District and vicinity, Florida, September 1986: U.S. Geological Survey Open-File Report 87-36, 1 sheet.

Tibbals, C.H., 1981, Computer simulation of the steady-state flow system of the Tertiary limestone (Floridan) aquifer system in east-central Florida: U.S. Geological Survey Water-Resources Investigations Open-File Report 81- 681, 31 p., and 9 sheets.

Toth, D.L., 1988, Salt water intrusion in coastal areas of Volusia, Brevard and Indian River Counties: St. Johns River Water Management District Technical Publication SJ 88-1, appendices and $159 \mathrm{p}$.
U.S. Soil Conservation Service, 1980, Soil survey of Volusia County, Florida: 207 p.

U.S. Environmental Protection Agency, 1989, Proposed rule, National primary and secondary drinking water regulations; (sec. 141.50, 141.51, 141.61, and 141.62 of pt. 141 and 143.3 of pt. 143): U.S. Federal Register, v. 54, no. 97, May 22, 1989 , p. 22,062-22,160.

Visher, F.N., and Wetterhall, W.S., 1967, Effect of filled cavities on the hydrology of the limestone terrain in Florida, in Abstracts of papers submitted for the meeting in Tallahassee, Florida, March 30-31 and April 1, 1967: Southeastern Section Geological Society America, p. 503.

White, W.A., 1970, The geomorphology of the Florida Peninsula: Florida Bureau of Geology Bulletin 51, $164 \mathrm{p}$.

Wood, W.W., 1976, Guidelines for collection and field analysis of ground-water samples for selected unstable constituents: Techniques of Water-Resources Investigations of the U.S. Geological Survey, Book 1, chap. D2, 24 p.

Wyrick, G.G., 1960, The ground-water resources of Volusia County, Florida: Florida Geological Survey Report of Investigations $22,65 \mathrm{p}$.

...- 1961, Records of wells in Volusia County, Florida: Florida Geological Survey Information Circular 24, $96 \mathrm{p}$.

Wyrick, G.G., and Leutze, W.P., 1956, Interim report on ground water resources of the northeastern part of Volusia County, Florida: Florida Geological Survey Information Circular 8, 75 p. 